\title{
Analysis and Load Rating of Pre-flex
}

\section{Composite Beams}

\section{US Army Corps of Engineers ${ }_{\circledast}$ \\ Engineer Research and Development Center}

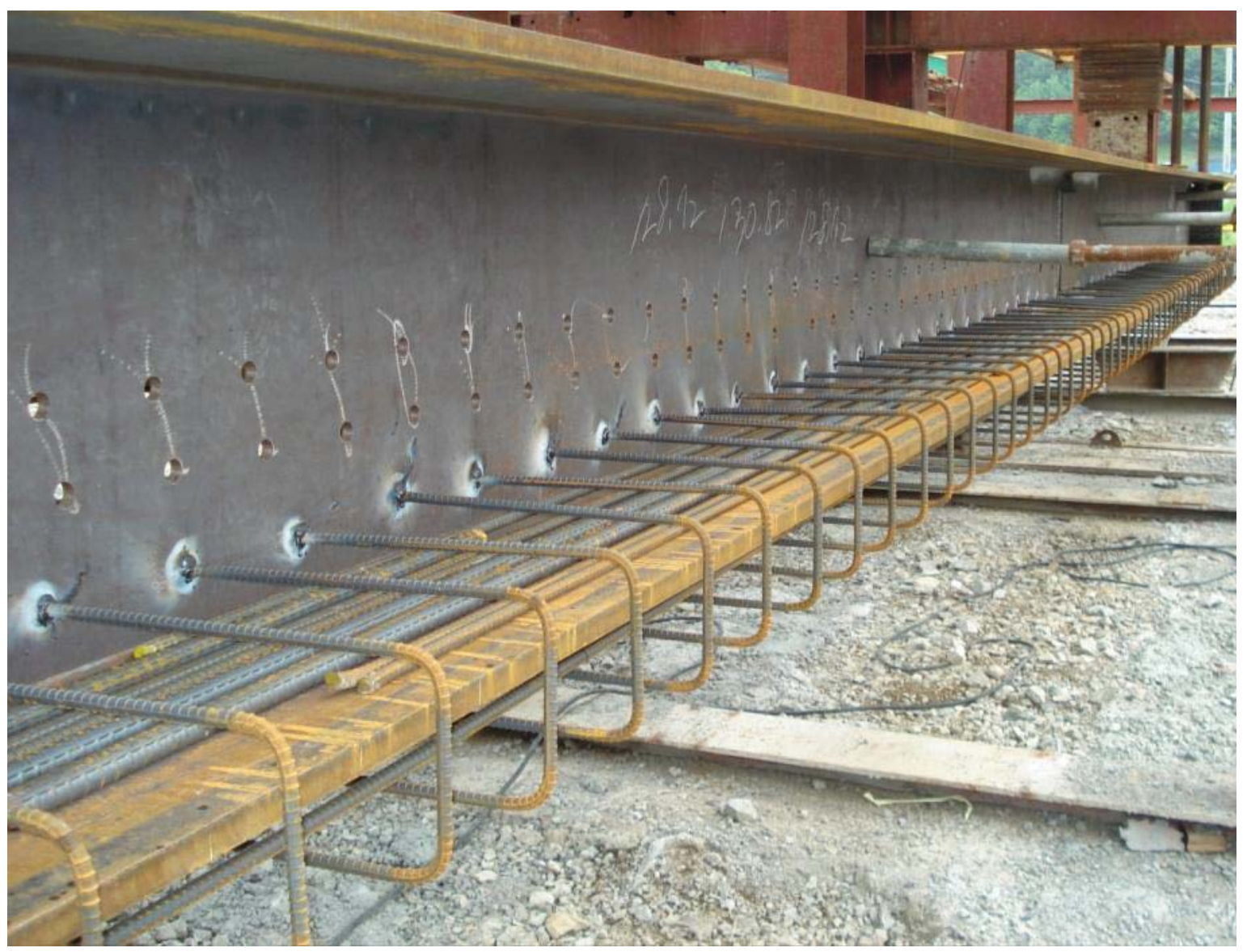




\section{Analysis and Load Rating of Pre-flex Composite Beams}

Genock Portela and Ulises Barajas

Department of Engineering Sciences and Materials

University of Puerto Rico, Mayaguez Campus

P.O. Box 9044

Mayaguez, PR 00681-9044

José A. Albarran-Garcia

Geotechnical and Structures Laboratory

U.S. Army Engineer Research and Development Center

3909 Halls Ferry Road

Vicksburg, MS 39180-6199

Final report

Approved for public release; distribution is unlimited.

Prepared for Headquarters, Installation Management Command (IMCOM)

San Antonio, TX 78201

Under Contract No. W912HZ-07-C-0053

Monitored by U.S. Army Engineer Research and Development Center 3909 Halls Ferry Road, Vicksburg, MS 39180-6199 


\begin{abstract}
This report describes a methodology for analysis and load rating of pre-flex beams subjected to vehicular and military loads. The methodology is based on service limits for different loading stages. The analysis is divided into an initial stage of pre-flexion of the non-composite beam, followed by the release and subsequent states of loading of a composite beam. Creep and shrinkage effects are considered in the analysis adopting Giacomo and Maninni (2006) and ACI 209 (1992) methods. An example bridge was used to describe a step-by-step process of analysis.
\end{abstract}

DISCLAIMER: The contents of this report are not to be used for advertising, publication, or promotional purposes. Citation of trade names does not constitute an official endorsement or approval of the use of such commercial products. All product names and trademarks cited are the property of their respective owners. The findings of this report are not to be construed as an official Department of the Army position unless so designated by other authorized documents. 


\section{Contents}

Figures and Tables........................................................................................................................................

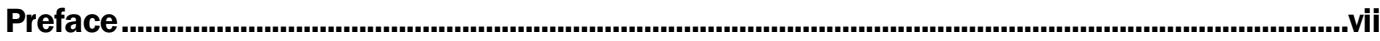

Unit Conversion Factors ......................................................................................................... viii

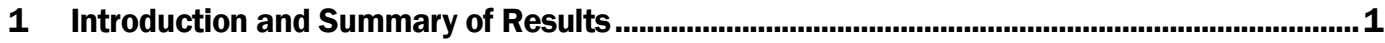

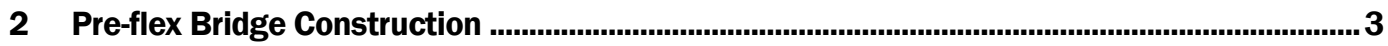

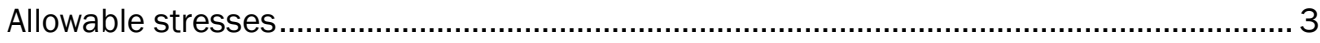

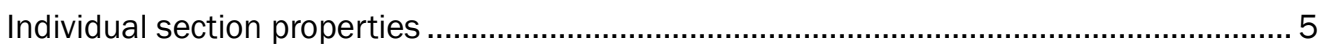

Steel girder with cover plates ........................................................................................ 7

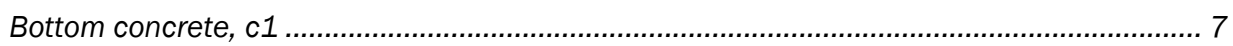

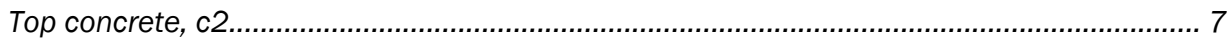

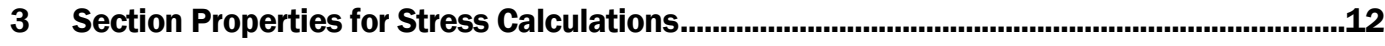

Steel and cover plates section (pre-deflection) ………................................................ 12

Concrete $\mathrm{c} 1$ at $\mathrm{t}=$ 3-day (recovery) ……................................................................ 13

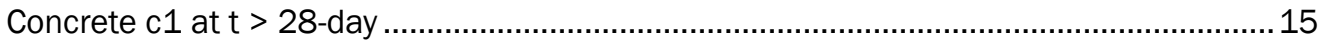

Concrete $\mathrm{c} 1$ and $\mathrm{c} 2$ at $\mathrm{t}>$ 28-day (fully composite) ...................................................... 16

4 Analysis of Pre-flex Beams................................................................................................19

Dead load analysis of components and attachments ................................................. 19

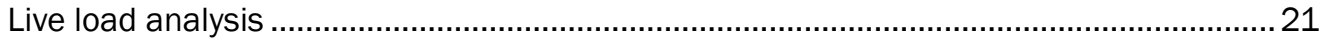

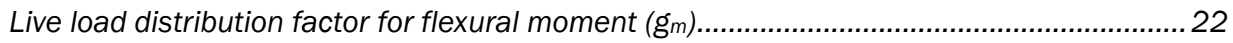

Live load distribution factor for shear $\left(g_{v}\right)$...................................................................... 22

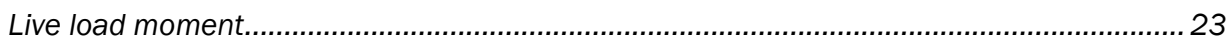

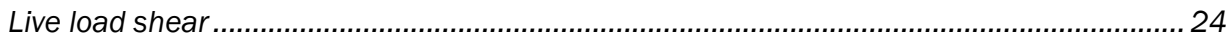

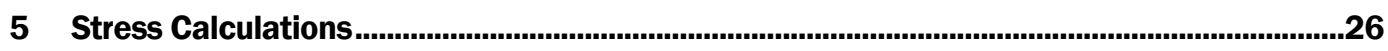

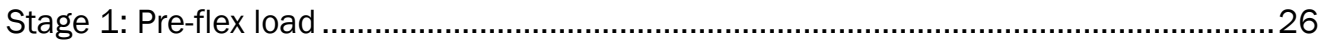

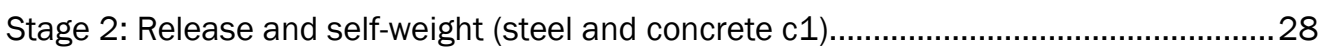

Stage 3: Additional loads due to concrete slab (c2), diaphragms, and concrete

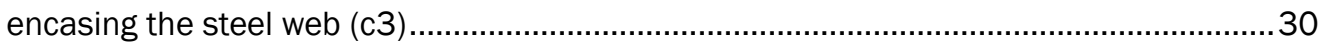

Stage 4: Additional weight due to superimposed loads on concrete slab .......................... 31

Stage 5: Live load effect on composite section ................................................................

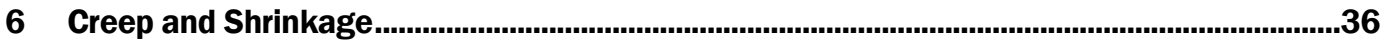

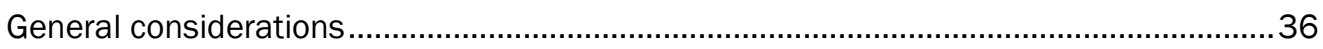

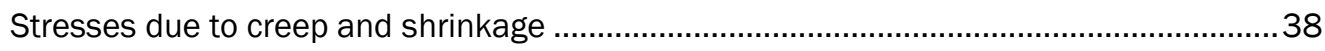

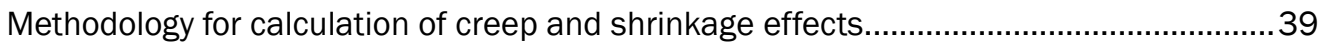

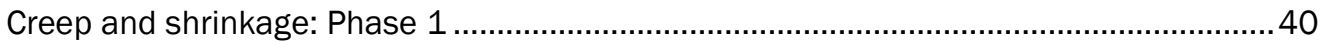

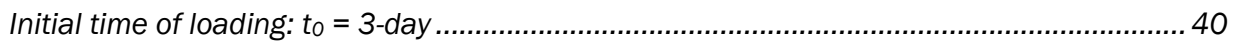

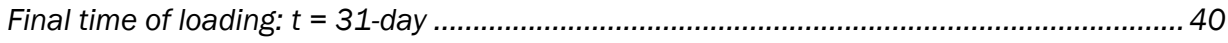




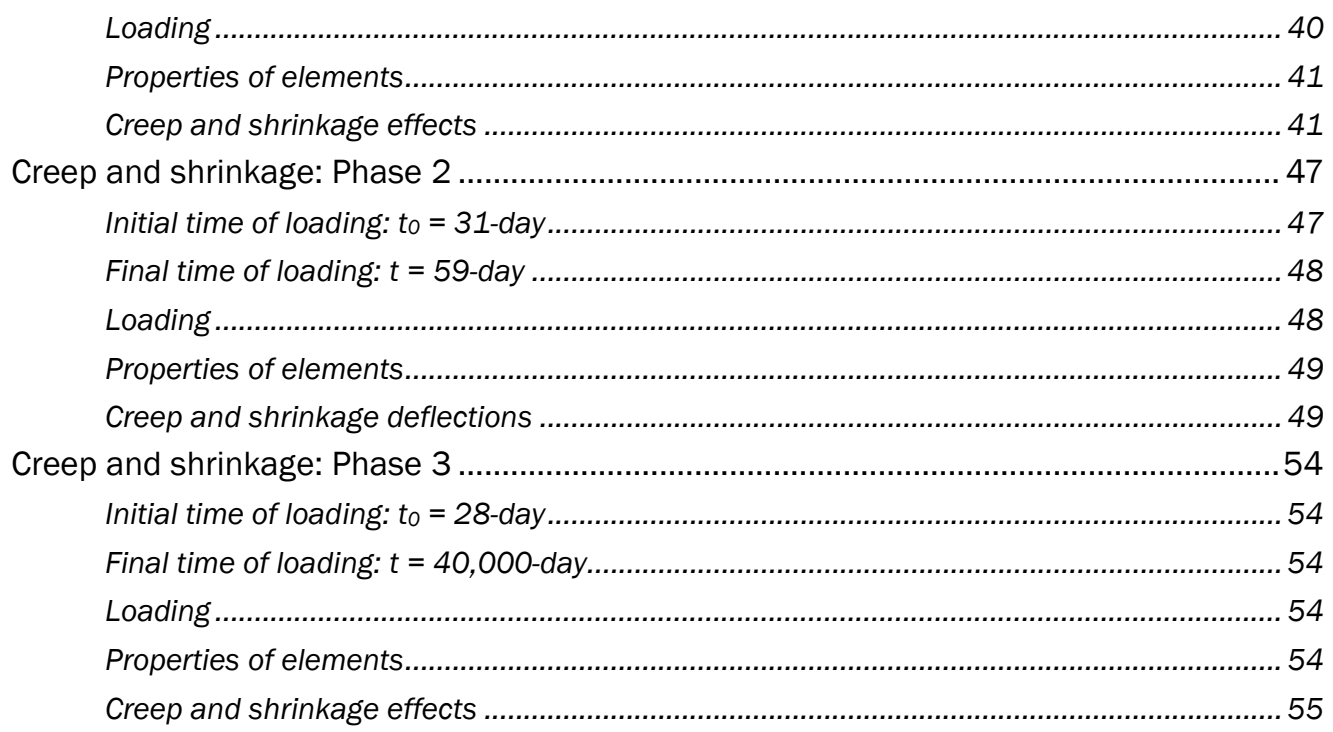

7 Shear Resistance .....................................................................................................................61

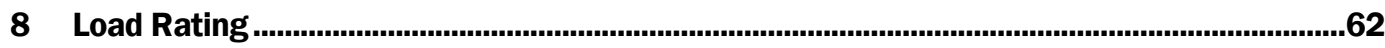

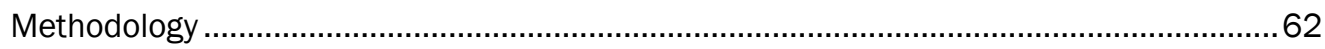

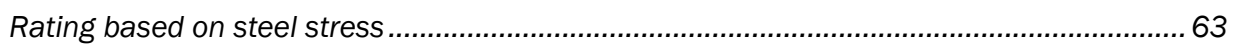

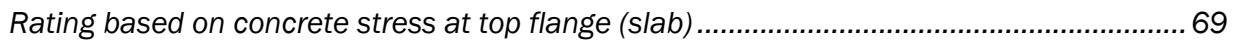

Rating based on concrete stress at bottom flange.......................................................... 71

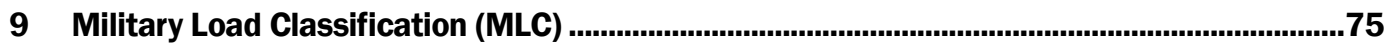

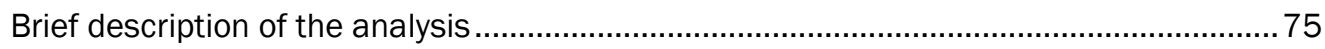

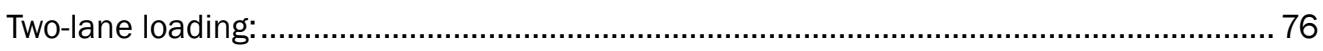

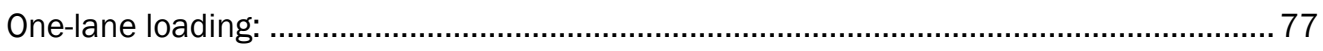

Roadway width classification and restrictions:..................................................... 78

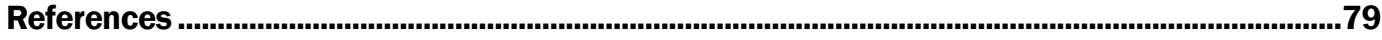

\section{Report Documentation Page}




\section{Figures and Tables}

\section{Figures}

Figure 1. Sequence for pre-flex beam construction: (Stage 1) Steel girder with camber; (Stage 2) Pre-flexure; (Stage 3) Encasement of the bottom flange; (Stage 4) Load release; (Stage 5) Concrete slab encasing top flange and web. .................................................................... 4

Figure 2. Bottom flange encasement of pre-flex beam under construction. ....................................... 4

Figure 3. Pre-flex beam with cast concrete at bottom flange ready for release stage. ......................... 4

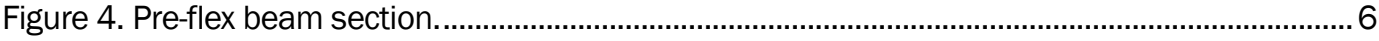

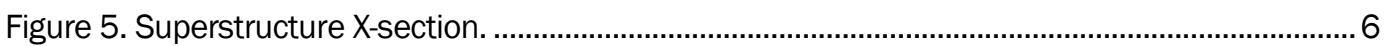

Figure 6. Steel and cover plates' properties................................................................................. 8

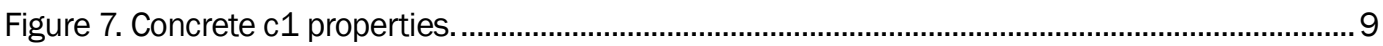

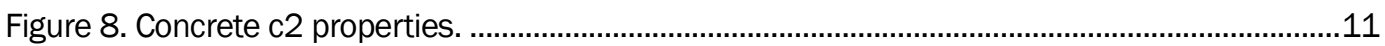

Figure 9. Properties of steel and concrete $\mathrm{c} 1$ transformed section at $\mathrm{t}=3$-day ...............................14

Figure 10. Properties of steel and concrete $\mathrm{c} 1$ transformed section $\mathrm{at} \mathrm{t}>\mathrm{28}$-day...........................15

Figure 11. Properties of steel and both concretes (c1 and c2) transformed section at t >

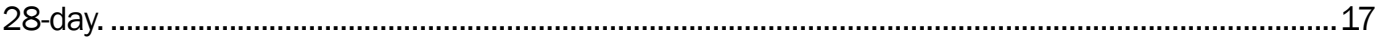

Figure 12. Design truck HS20-44..........................................................................................21

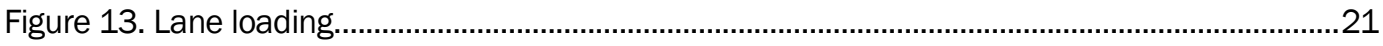

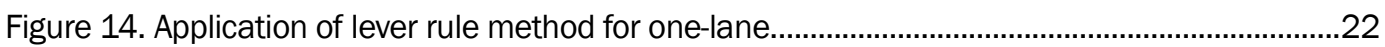

Figure 15. Application of lever rule method for two-lane..................................................................23

Figure 16. Point loads acting during the pre-flexion process. ...........................................................2

Figure 17. Full composite section and its centroid location. ..............................................................32

Figure 18. Sign convention of internal and external forces, from Giacomo and Mannini..................38

Figure 19. Loads and element sections considered for Phase 1 of creep and shrinkage. ................41

Figure 20. Loads and element sections considered for Phase 2 of creep and shrinkage................49

Figure 21. Loads and element sections considered for Phase 3 of creep and shrinkage. ...............55

Figure 22. Horseshoe shear connectors installed on the top flange of the pre-flex beam. ..............61

Figure 23. Bridge posting sign based on the ASR method..............................................................78

\section{Tables}

Table 1. Steel girder and over plate section computations. ...............................................................

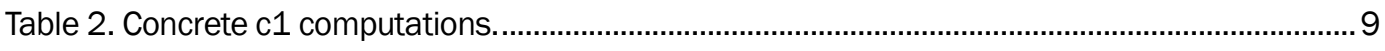

Table 3. Concrete $\mathrm{c} 2$ computations.........................................................................................10

Table 4. Steel and concrete $\mathrm{c} 1$ transformed section at $\mathrm{t}$ = 3-day...................................................13

Table 5. Steel and concrete $c 1$ transformed section at $t>28$-day ..................................................15

Table 6. Steel and both concretes (c1 and c2) transformed section at t > 28-day. ..........................17

Table 7. Stress values for different stages of loading....................................................................35 
Table 8. Stress values including creep and shrinkage stresses....................................................60

Table 9. Summary of load rating factors based on ASR method. …….............................................. 74

Table 10. Military Load Class live load effects - Inventory two-lane..................................................76

Table 11. Military Load Class live load effects - Operating two-lane....................................................76

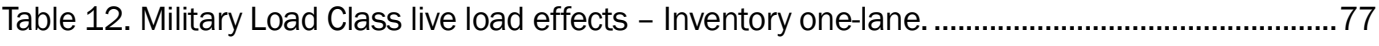

Table 13. Military Load Class live load effects - Operating one-lane.................................................77

Table 14. Recommended MLC for target pre-flex bridge. ...................................................................78 


\section{Preface}

This report describes the process for design and presents a methodology for load rating calculations of pre-flex bridges. This project was arranged and supervised by Terry R. Stanton of the U.S. Army Engineer Research and Development Center (ERDC.)

The work was performed jointly by personnel from the University of Puerto Rico, Mayagüez Campus (UPRM), under Contract No. W912HZ07-C-0053, and personnel of the Structural Engineering Branch (StEB), Geotechnical and Structures Laboratory (GSL), of ERDC. This report was prepared by Genock Portela, Ulises Barajas, and Elvin Perez, UPRM. Technical review of the document was performed by J osé A. AlbarranGarcia, StEB.

The Army Bridge Inspection Program is sponsored by the Army Transportation Infrastructure Program (ATIP) of the Headquarters, Installation Management Command (IMCOM), San Antonio, TX. Funding for this investigation was provided by IMCOM, and questions concerning the project should be directed to Ali A. Achmar, IMCOM ATIP Program Manager (ali.achmar@us.army.mil).

This publication was prepared under the overall project supervision of Terry R. Stanton, Chief, StEB; Dr. Bartley P. Durst, Chief, Geosciences and Structures Division; Dr. William P. Grogan, Deputy Director, GSL; and Dr. David W. Pittman, Director, GSL.

COL Kevin J . Wilson was Commander and Executive Director of ERDC, and Dr. J effery P. Holland was the Director. 


\section{Unit Conversion Factors}

\begin{tabular}{|c|c|c|}
\hline Multiply & By & To Obtain \\
\hline cubic feet & 0.02831685 & cubic meters \\
\hline cubic inches & 1.6387064 E-05 & cubic meters \\
\hline feet & 0.3048 & meters \\
\hline inches & 0.0254 & meters \\
\hline inch-pounds (force) & 0.1129848 & newton meters \\
\hline ounces (mass) & 0.02834952 & kilograms \\
\hline pounds (force) & 4.448222 & newtons \\
\hline pounds (force) per foot & 14.59390 & newtons per meter \\
\hline pounds (force) per inch & 175.1268 & newtons per meter \\
\hline pounds (force) per square foot & 47.88026 & pascals \\
\hline pounds (force) per square inch & 6.894757 & kilopascals \\
\hline pounds (mass) & 0.45359237 & kilograms \\
\hline pounds (mass) per cubic foot & 16.01846 & kilograms per cubic meter \\
\hline pounds (mass) per cubic inch & $2.757990 \mathrm{E}+04$ & kilograms per cubic meter \\
\hline pounds (mass) per square foot & 4.882428 & kilograms per square meter \\
\hline pounds (mass) per square yard & 0.542492 & kilograms per square meter \\
\hline square feet & 0.09290304 & square meters \\
\hline square inches & 6.4516 E-04 & square meters \\
\hline tons (force) & $8,896.443$ & newtons \\
\hline tons (force) per square foot & 95.76052 & kilopascals \\
\hline tons (long) per cubic yard & $1,328.939$ & kilograms per cubic meter \\
\hline tons ( 2,000 pounds, mass) & 907.1847 & kilograms \\
\hline tons ( 2,000 pounds, mass) per square foot & $9,764.856$ & kilograms per square meter \\
\hline
\end{tabular}




\section{Introduction and Summary of Results}

Pre-flex technology was introduced early in the 1950's by Belgium engineer Abraham Lipski and Professor Louis Baes (Baes and Lipski 1954.) The technology provides an alternative for structures that demand slender beams in long spans and is useful when deflections must be limited (serviceability criteria) and when structures restrict vertical clearance. The pre-flex solution becomes reasonably attractive when strict limitations on clearance govern the design and dictate the use of a fairly slender structure. Pre-flex technology has been successfully applied to buildings and bridges in Asia and Europe (Staquet et al. 2004). The Southern Tower (Tour du Midi) in Belgium employs this system. Other common applications are related to vehicular and railroad bridges.

The pre-flex system consists of steel beams encased in concrete at different stages of construction in order to generate composite beam action and, in turn, increase their flexural capacity and stiffness. With regard to live loads, the contribution of the concrete flange to the total moment of inertia can be significant. The process is based on induced pre-flexion not exceeding permissible flexural limits in the steel beam. At this step, the beam bottom flange is encased in high-strength concrete and remains deflected until the concrete reaches a specified compressive strength. When concrete attains this compressive strength, the beam is released, counteracting the internal stresses that may develop during bridge construction and throughout the service life of the structure. However, in order to ensure durability, cracking of the concrete flange should be prevented over the life of the structure. Therefore, predicting the development of stresses in the concrete flange is important.

During pre-flex construction, the steel beams are subjected to greater loading than the load conditions they are anticipated to experience throughout their service life. The constant monitoring during the preflexion process and the quality control of concrete mixtures provide a higher degree of safety in comparison to other systems.

This report presents a procedure for evaluating simply supported pre-flex beams under dead load, superimposed dead load, and vehicular loads (live loads.) The main objective is to present a methodology for estimating 
inventory and operating load rating factors due to flexural and shear stresses generated by live loads. For analysis, the secondary effects of creep and shrinkage are also taken into account.

To illustrate the steps of the analysis, an example pre-flex bridge was introduced to a pre-flexion load of $1.459 \mathrm{MN}$. The load rating factors for flexural stress were estimated for stress limits at the extreme top and bottom surfaces of the steel and the extreme top and bottom fibers of the concrete. For shear, only the allowable stress of the steel web was considered in the analysis. The controlling load rating value was associated with the limiting stress at the extreme bottom fiber of the concrete with a value of 1.19 and 2.82 at the inventory and operating levels, respectively, for an HS20-44 vehicle. 


\section{Pre-flex Bridge Construction}

The pre-flexion process starts with a cambered I-shaped steel girder with welded cover plates on its top and bottom flanges. The steel girder is simply supported and loaded at quarter points of its span. Normally, the estimation of the limiting point loads is based on a permissible flexural stress of the steel girder. For bridge applications, the loads induce a tensile stress below the neutral axis of the beam, with the maximum stress occurring at the extreme outer surface of the bottom flange. Similarly, compression stresses develop above the neutral axis with the maximum stress occurring at the extreme outer surface of the top flange. Once the steel beam is at its maximum deflection, the bottom flange is encased in high-strength concrete, known as the first stage concrete (c1) or pre-flex concrete. Welded rebar around the bottom flange and welded shear studs (see Figure 2) provide a means for load transfer between the steel beam and the c1 concrete. As an early concrete compressive strength is attained $\left(0.4 f_{c}^{\prime}\right.$ of high- strength concrete $\left.-5,150 \mathrm{~N} / \mathrm{cm}^{2}\right)$, typically achieved on the third day ( $t=3$-day), the load on the composite beam is removed. During the recovery process, compressive stress is induced in the first stage concrete (c1.) The composite action provided by concrete c1, partially restrains the deflected steel beam, resulting in permanent deflections and a new distribution of stresses along the cross section of the composite beam. If shoring is not provided during construction, the composite section at this first stage is used for the stress calculation during placement. Furthermore, this section is also considered in the calculation of stresses produced by the weight of the fresh concrete of the top slab (c2), including temporary formwork. Figure 1 shows the sequence of construction divided into five stages. Some examples of on-site construction are provided in Figures 2 and 3.

A second composite action takes place between the steel top flange and the concrete slab, called the second stage concrete (c2.) In order to provide adequate load transfer between steel and concrete, shear connectors are welded to the top flange. For analysis purposes, the stresses produced by vehicular loads are obtained on a full composite section basis (steel $+\mathrm{c} 1+\mathrm{c} 2$ ).

\section{Allowable stresses}

Pre-flex design consists of an iterative process in which the geometry, steel properties, and concrete mechanical properties are varied in order to 
STAGE 1.
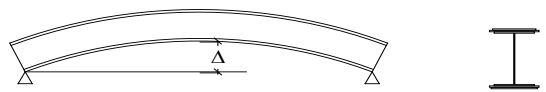

STAGE 2.
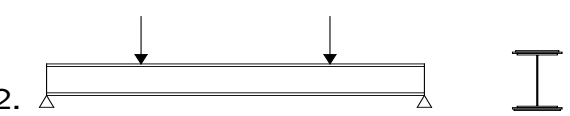

STAGE

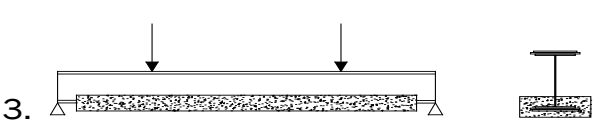

STAGE 4. ETH

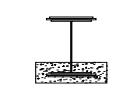

STAGE 5. Aris.

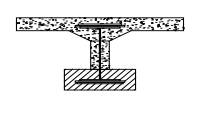

Figure 1. Sequence for pre-flex beam construction: (Stage 1) Steel girder with camber; (Stage 2) Pre-flexure; (Stage 3) Encasement of the bottom flange; (Stage 4) Load release; (Stage 5) Concrete slab encasing top flange and web.

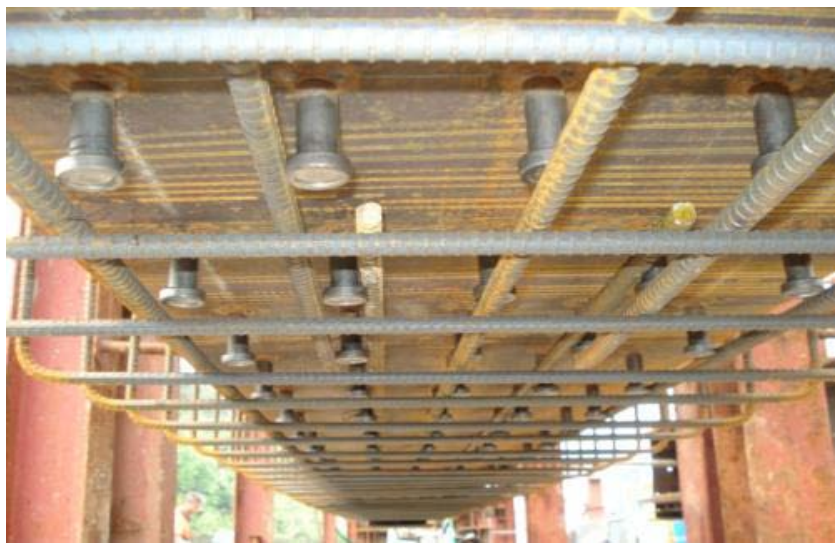

Figure 2. Bottom flange encasement of pre-flex beam under construction.

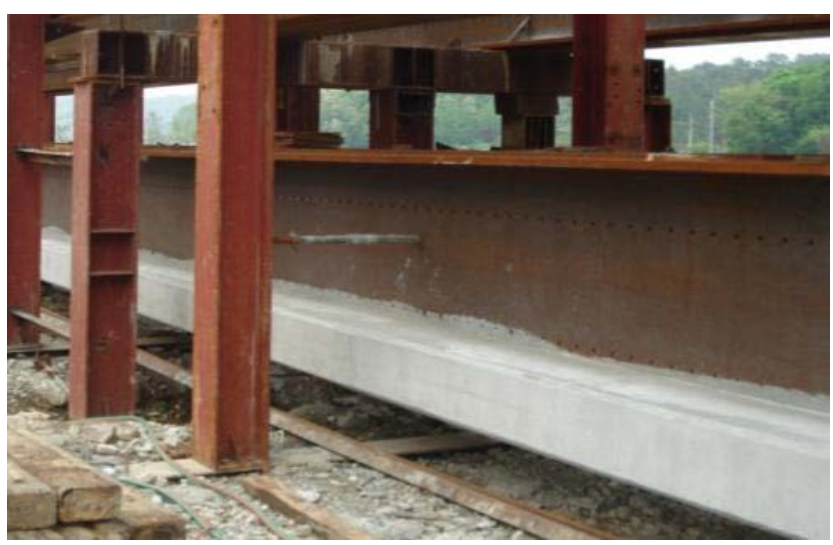

Figure 3. Pre-flex beam with cast concrete at bottom flange ready for release stage. 
reduce the resulting stresses below the established limits. Based on literature by SAMPYO manufacturers (1985), the following allowable stresses are considered in the design process.

For the steel beams, the allowable tensile stress is limited to $0.80 \mathrm{f}_{\mathrm{y}}$ (elastic yield limit). The tensile stress is measured at the extreme fiber of the top (and bottom flange when applicable). This limit is set for both the construction and the service of the beam. The allowable shear stress is limited to $0.55 \mathrm{fy}$, and only the steel web is considered for shear resistance. The horizontal shear at the top flange is transferred to the concrete slab by shear connectors. The load carrying capacity of horseshoe connectors (typically used for this system, see Figure 22) is specified by its manufacturers and varies from $19.62 \mathrm{kN}(4,410 \mathrm{lb})$ to $44.1 \mathrm{kN}(9,920 \mathrm{lb})$.

Common practice in the design of reinforced concrete assumes no concrete resistance to tensile stress. Only compressive stresses are considered in the top (c2) and bottom concrete (c1). The allowable compressive stress of the first stage concrete (c1) is commonly limited to half of its 28-day compressive strength $\left(0.5 \mathrm{f}_{\mathrm{c}}^{\prime}\right)$, based on test cylinders. This limit is temporary and applies only at the moment the load is removed during the fabrication. Once in service, the allowable compressive stress is limited to $0.4 \mathrm{f}_{\mathrm{c}}^{\prime}$, a value adopted for the calculations presented in this report. Transverse reinforcement is provided to $\mathrm{c} 1$ concrete to account for shear stresses in concrete. Shear reinforcement is commonly placed at one quarter of the span from each support.

For the concrete section provided by the concrete slab (c2), the allowable compressive stress depends on the ratio of the moment resistance between the final beam (composite action) and the uncased steel beam. If the moment resistance of the composite beam is between 1.0 and 1.25 times the resisting moment of the steel beam, the allowable stress recommended is $0.4 \mathrm{f}_{\mathrm{c}}^{\prime}$. When the moment resistance of the composite beam is greater than 1.25 times the resisting moment of the steel beam, the recommended

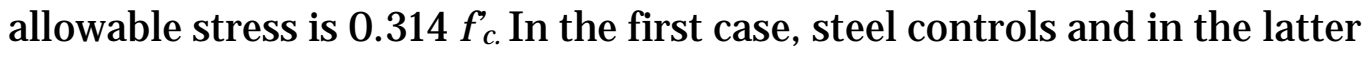
case, concrete controls the resistance of the composite beam.

\section{Individual section properties}

An example bridge has been selected to present the step-by-step calculations. Figure 5 shows the cross section and configuration of the target bridge. 


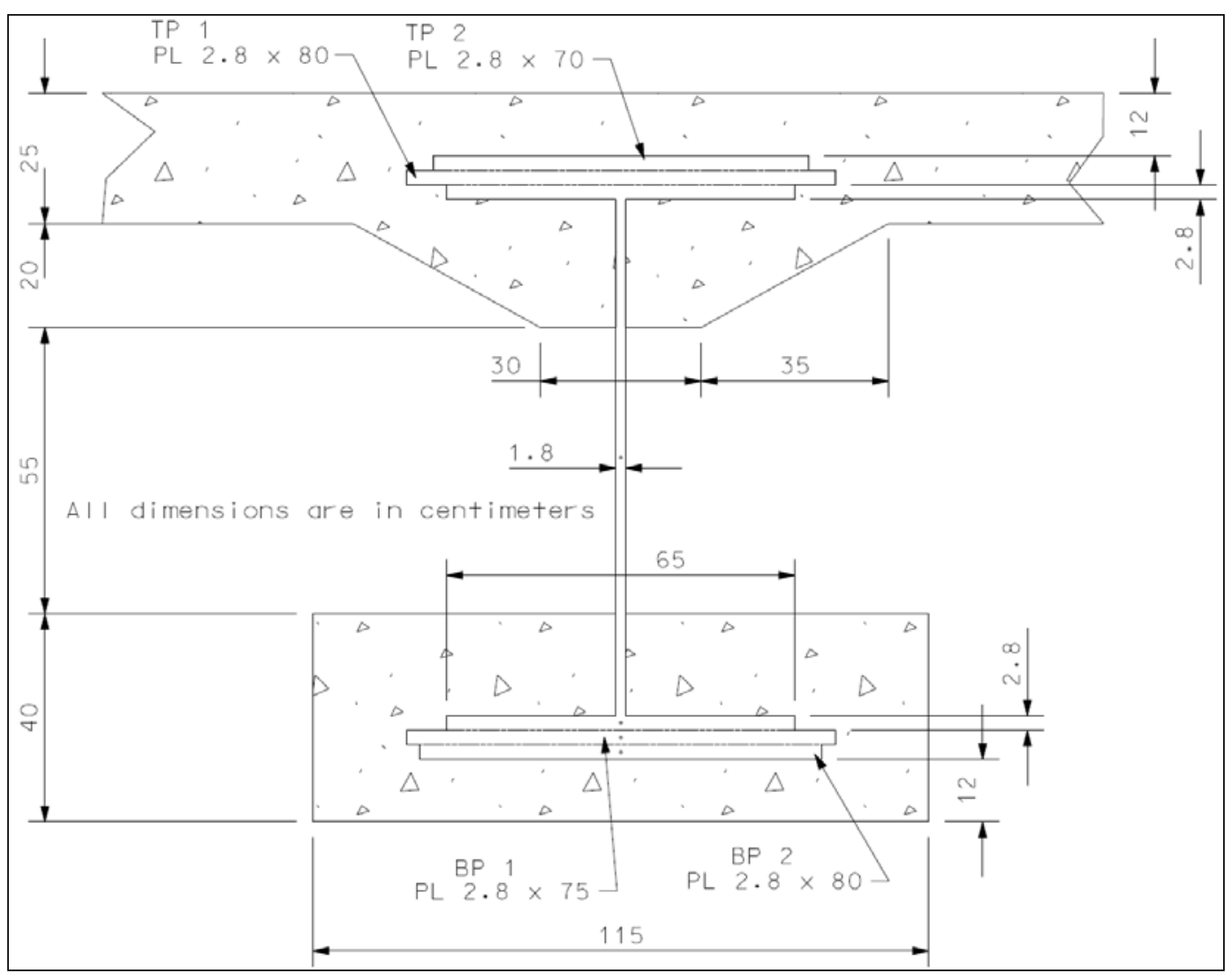

Figure 4. Pre-flex beam section.

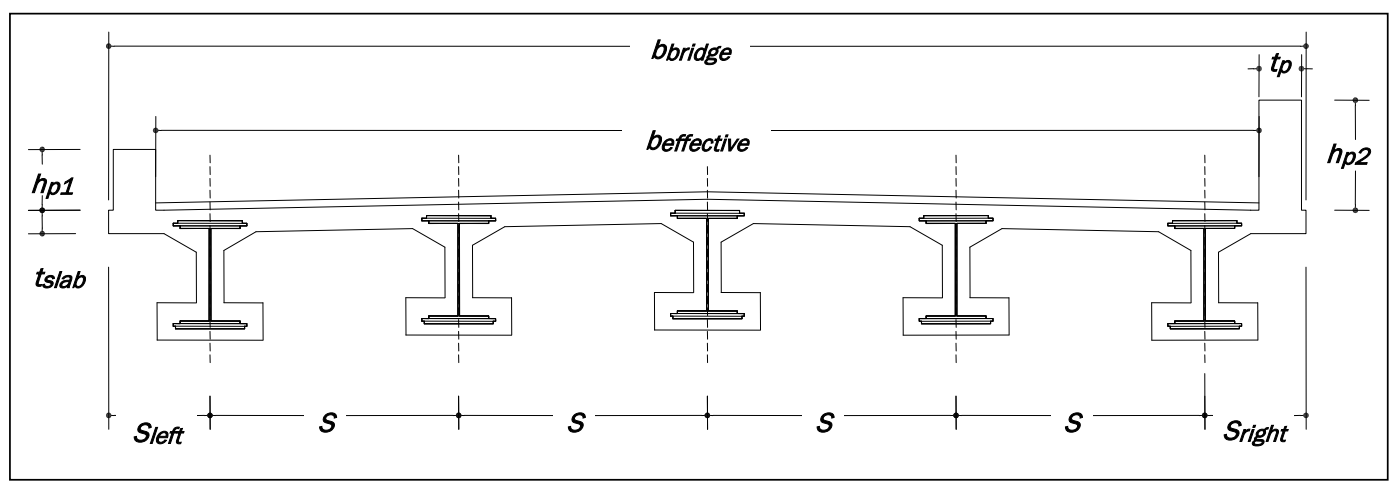

Figure 5. Superstructure X-section.

The sections for the different stages of pre-flex beam construction are:

1. Steel ginder with cover plates on its top and bottom flanges

2. Bottom flange encased in concrete or first stage concrete (c1)

3. Top flange encased in slab concrete or second stage concrete (c2)

Here, the calculations of the properties of each of the described sections are shown. The geometrical properties are area, moment of inertia, and 
section moduli; and these will be used to calculate the pre-flex beam composite section properties at different loading conditions.

\section{Steel girder with cover plates}

The computations necessary to obtain the steel properties are summarized in Table 1.

Table 1. Steel girder and over plate section computations.

\begin{tabular}{|c|c|c|c|c|c|c|c|c|}
\hline \multicolumn{9}{|c|}{ Stage 1 - Girder and Cover Plates } \\
\hline \multirow{2}{*}{ Section } & b & $d$ & Area & Yi & $($ Area $)(Y i)$ & I & di & $\left(\right.$ Area) $(\mathrm{di})^{2}$ \\
\hline & $\mathrm{mm}$ & $\mathrm{mm}$ & $\mathrm{cm}^{2}$ & $\mathrm{~cm}$ & $\mathrm{~cm}^{3}$ & $\mathrm{~cm}^{4}$ & $\mathrm{~cm}$ & $\mathrm{~cm}^{4}$ \\
\hline TP 2 & 700 & 28 & 196.0 & 1.4 & 274.4 & 128.1 & -57.17 & 640,550 \\
\hline TP 1 & 800 & 28 & 224.0 & 4.2 & 940.8 & 146.3 & -54.37 & 662,102 \\
\hline Top Flange & 650 & 28 & 182.0 & 7.0 & $1,274.0$ & 118.9 & -51.57 & 483,974 \\
\hline Web & 18 & 992 & 178.6 & 58.0 & $10,356.5$ & $146,428.7$ & -0.57 & 57 \\
\hline Bottom Flange & 650 & 28 & 182.0 & 109.0 & $19,838.0$ & 118.9 & 50.43 & 462,907 \\
\hline BP 1 & 800 & 28 & 224.0 & 111.8 & $25,043.2$ & 146.3 & 53.23 & 634,751 \\
\hline \multirow[t]{2}{*}{ BP 2} & 750 & 28 & 210.0 & 114.6 & $24,066.0$ & 137.2 & 56.03 & 659,327 \\
\hline & & & 1,397 & & 81,793 & 147,224 & & $3,543,669$ \\
\hline
\end{tabular}

where:

$$
\begin{aligned}
\mathrm{b} & =\text { element width } \\
\mathrm{d} & =\text { element depth } \\
\mathrm{Yi} & =\text { distance from the reference point to the element's centroid } \\
\mathrm{di} & =\text { distance from the element's centroid to the neutral axis }
\end{aligned}
$$

\section{Bottom concrete, $\mathrm{c1}$}

The computations necessary to obtain the concrete c1 properties are summarized in Table 2.

\section{Top concrete, c2}

The computations necessary to obtain the concrete c2 properties are summarized in Table 3. 


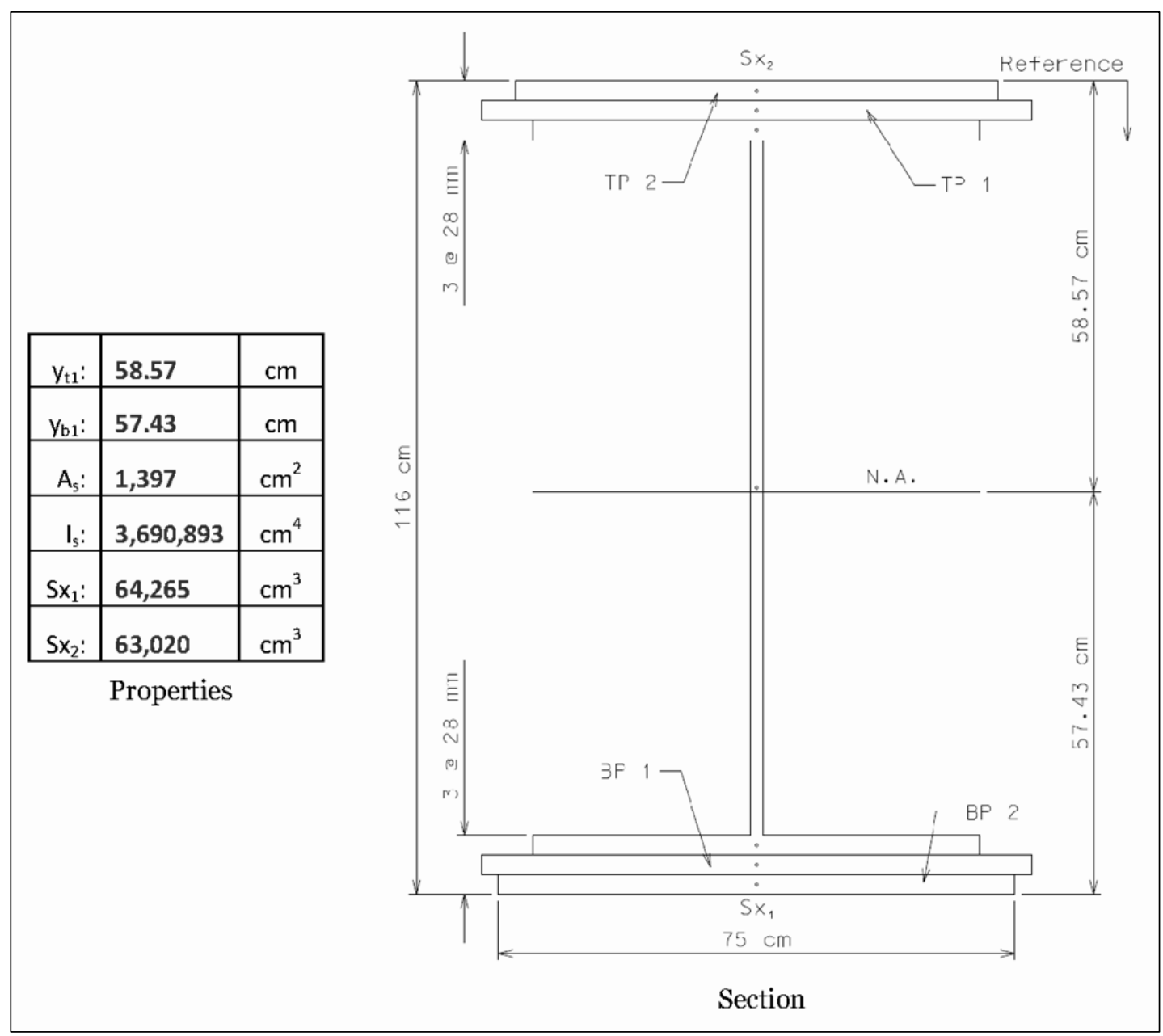

Figure 6. Steel and cover plates' properties.

where:

$\mathrm{y}_{\mathrm{t} 1}=$ distance from the neutral axis to the extreme top steel surface

$\mathrm{y}_{\mathrm{b} 1}=$ distance from the neutral axis to the extreme bottom steel surface

$\mathrm{A}_{\mathrm{s}}=$ total steel area

$\mathrm{I}_{\mathrm{s}}=$ total moment of inertia about the neutral axis

$\mathrm{Sx}_{1}=$ section modulus with respect to the extreme bottom steel surface

$\mathrm{Sx}_{2}=$ section modulus with respect to the extreme top steel surface 
Table 2. Concrete c1 computations.

\begin{tabular}{|l|l|l|l|l|l|l|l|l|}
\hline \multicolumn{1}{|c|}{ Section } & b & d & Area & Yi & (Area)(Yi) & I & di & (Area) (di) \\
\cline { 2 - 10 } & $\mathbf{m m}$ & $\mathbf{m m}$ & $\mathbf{c m}^{2}$ & $\mathbf{c m}$ & $\mathbf{c m}^{3}$ & $\mathbf{c m}^{4}$ & $\mathbf{c m}$ & cm $^{4}$ \\
\hline Concrete & 1,150 & 400 & $4,600.0$ & 20.0 & $92,000.0$ & $613,333.3$ & -0.52 & 1,251 \\
\hline Web & 18 & 196 & -35.3 & 30.2 & $-1,065.5$ & $-1,129.4$ & 9.68 & $-3,305$ \\
\hline Bottom Flange & 650 & 28 & -182.0 & 19.0 & $-3,458.0$ & -118.9 & -1.52 & -421 \\
\hline BP 1 & 800 & 28 & -224.0 & 16.2 & $-3,628.8$ & -146.3 & -4.32 & $-4,183$ \\
\hline BP 2 & 750 & 28 & -210.0 & 13.4 & $-2,814.0$ & -137.2 & -7.12 & $-10,650$ \\
\hline & & & 3,949 & & 81,034 & 611,801 & & $-17,309$ \\
\hline
\end{tabular}

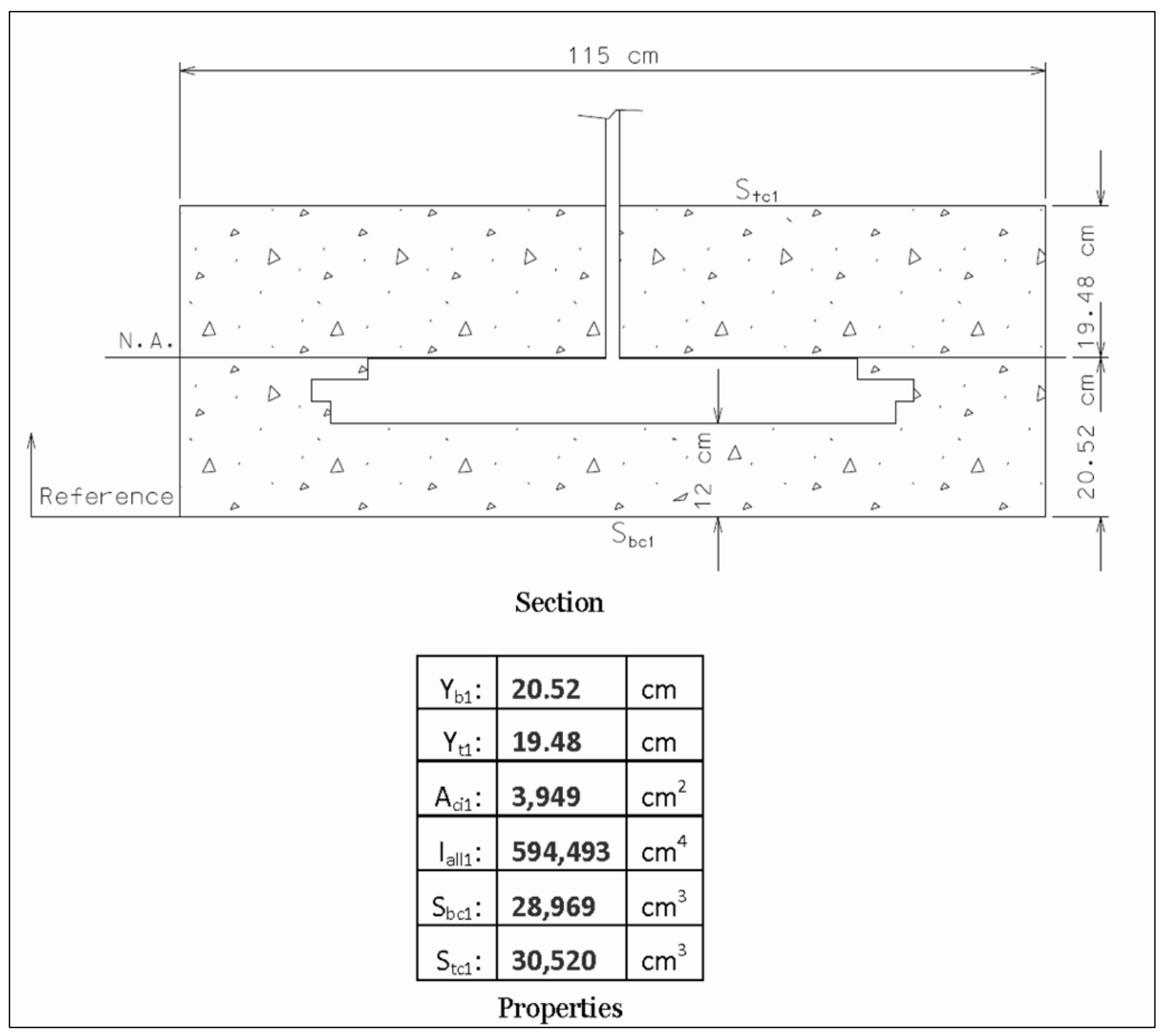

Figure 7. Concrete $c 1$ properties. 
where:

$$
\begin{aligned}
\mathrm{yb}_{\mathrm{b} 1}= & \text { distance from the neutral axis to the extreme bottom concrete } \\
& \text { surface } \\
\mathrm{y}_{\mathrm{t} 1}= & \text { distance from the neutral axis to the extreme top concrete } \\
& \text { surface } \\
\mathrm{A}_{\mathrm{c} 1}= & \text { concrete } \mathrm{c} 1 \text { area } \\
\mathrm{I}_{\mathrm{all} 1}= & \text { moment of inertia of concrete } \mathrm{c} 1 \text { about the neutral axis } \\
\mathrm{S}_{\mathrm{bc} 1}= & \text { section modulus with respect to the extreme bottom concrete } \\
& \text { surface } \\
\mathrm{S}_{\mathrm{tc} 1}= & \text { section modulus with respect to the extreme top concrete } \\
& \text { surface }
\end{aligned}
$$

Table 3. Concrete $\mathrm{c} 2$ computations.

\begin{tabular}{|l|l|l|l|l|l|l|l|l|}
\hline \multicolumn{1}{|c|}{ Section } & b & d & Area & Yi & (Area)(Yi) & I & di & (Area) (di) \\
\cline { 2 - 9 } & mm & mm & $\mathrm{cm}^{2}$ & cm & cm $^{3}$ & cm $^{4}$ & cm & cm $^{4}$ \\
\hline Slab & 2,700 & 250 & $6,750.0$ & 12.5 & $84,375.0$ & $351,562.5$ & -3.22 & 69,952 \\
\hline Concrete Trian. & 700 & 200 & 700.0 & 31.7 & $22,166.7$ & $15,555.6$ & 15.95 & 178,025 \\
\hline Concrete Rect. & 300 & 200 & 600.0 & 35.0 & $21,000.0$ & $20,000.0$ & 19.28 & 223,050 \\
\hline TP 2 & 700 & 28 & -196.0 & 13.4 & $-2,626.4$ & -128.1 & -2.32 & $-1,054$ \\
\hline TP 1 & 800 & 28 & -224.0 & 16.2 & $-3,628.8$ & -146.3 & 0.48 & -52 \\
\hline Top Flange & 650 & 28 & -182.0 & 19.0 & $-3,458.0$ & -118.9 & 3.28 & $-1,959$ \\
\hline Web & 18 & 246 & -44.3 & 32.7 & $-1,448.0$ & $-2,233.0$ & 16.98 & $-12,768$ \\
\hline & & & 7,404 & & 116,381 & 384,492 & & 455,194 \\
\hline
\end{tabular}




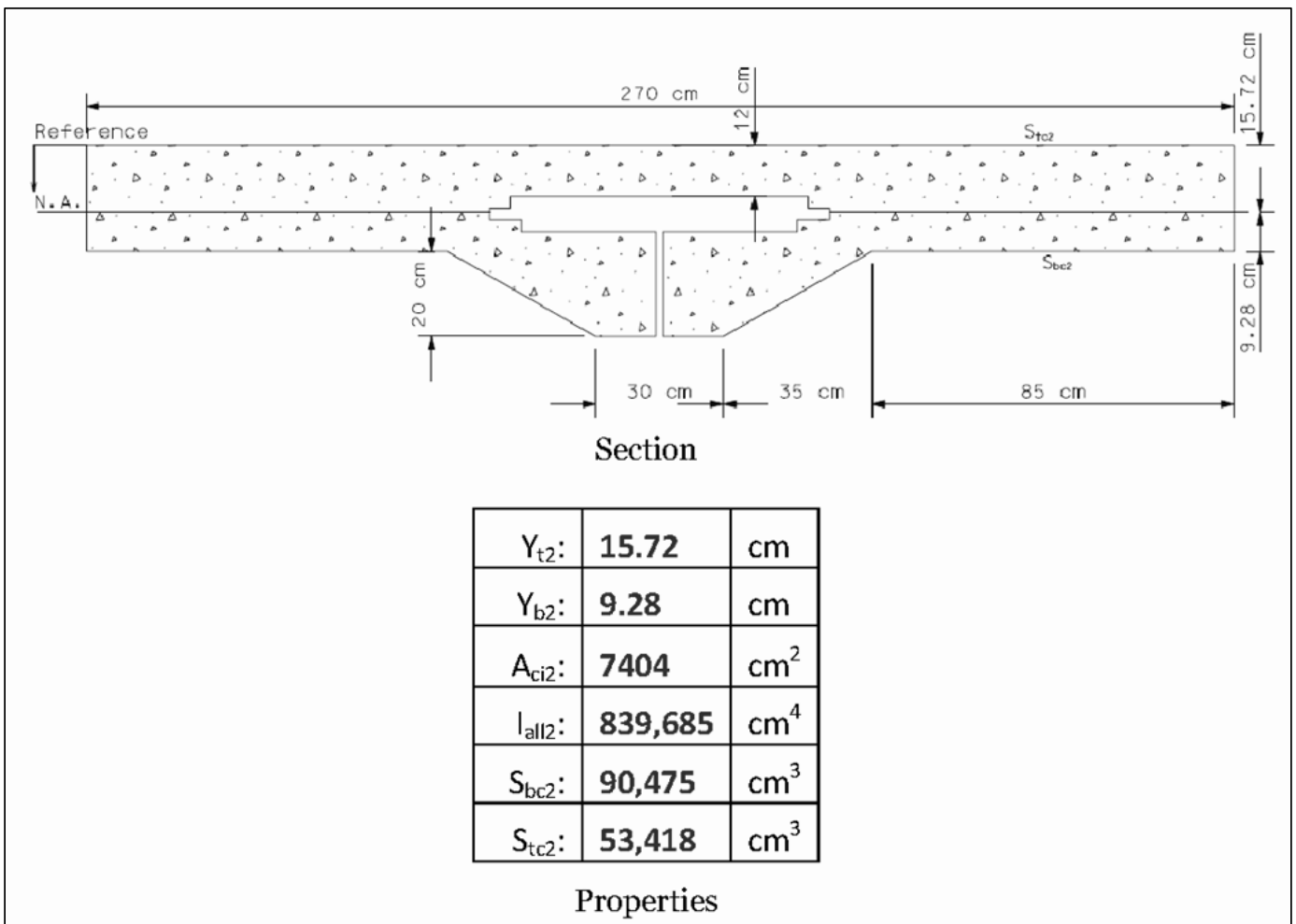

Figure 8. Concrete $c 2$ properties.

where:

$\mathrm{y}_{\mathrm{t} 2}=$ distance from the neutral axis to the extreme top concrete slab surface

$\mathrm{y}_{\mathrm{b} 2}=$ distance from the neutral axis to the extreme bottom concrete slab surface

$\mathrm{A}_{\mathrm{ci} 2}=$ concrete $\mathrm{c} 2$ area

$\mathrm{I}_{\text {all2 }}=$ moment of inertia of concrete $\mathrm{c} 2$ about the neutral axis

$\mathrm{S}_{\mathrm{bc} 2}=$ section modulus with respect to the extreme bottom concrete slab surface

$\mathrm{S}_{\mathrm{tc} 2}=$ section modulus with respect to the extreme top concrete slab surface 


\section{Section Properties for Stress Calculations}

Moments of inertia and sections moduli at different loading stages are the key parameters for the calculation of stresses and deflections of the beam. These properties are computed in accordance with the elastic theory using the transformed area method. For stress calculations at top and bottom flanges, a transformed steel section is calculated. Similarly, for stress calculations at the extreme concrete top and bottom fibers, a transformed concrete section is calculated. (Equation 1) For example, the area of concrete is transformed into an equivalent steel area by dividing its area by the modular ratio, $\mathrm{n}$ :

$$
\mathrm{n}=\frac{\mathrm{E}_{\mathrm{s}}}{\mathrm{E}_{\mathrm{c}}}
$$

where:

$$
\begin{aligned}
& \mathrm{n}=\text { modular ratio } \\
& \mathrm{E}_{\mathrm{s}}=\text { elastic modulus of steel } \\
& \mathrm{E}_{\mathrm{c}}=\text { elastic modulus of concrete }
\end{aligned}
$$

The composite section properties used for stress analysis depend on the loading case under consideration.

\section{Steel and cover plates section (pre-deflection)}

The first loading stage is the pre-deflection. At this stage, only the section properties of the (cambered) steel girder and its plates are used (see Table 1 and Figure 6). The section moduli for steel beams, including top and bottom plates, referenced from the extreme steel surfaces are:

$$
\begin{aligned}
& \mathrm{Sx}_{1}=\frac{\mathrm{I}_{\mathrm{s}}}{\mathrm{y}_{\mathrm{b} 1}}=\frac{3,690,893 \mathrm{~cm}^{4}}{57.43 \mathrm{~cm}}=64,265 \mathrm{~cm}^{3} \\
& \mathrm{Sx}_{2}=\frac{\mathrm{I}_{\mathrm{s}}}{\mathrm{y}_{\mathrm{t} 1}}=\frac{3,690,893 \mathrm{~cm}^{4}}{58.57 \mathrm{~cm}}=63,020 \mathrm{~cm}^{3}
\end{aligned}
$$




\section{Concrete $\mathbf{c 1}$ at $\mathbf{t}=$ 3-day (recovery)}

The second loading stage, recovery, consists of removing the pre-flexion loads. For this stage, composite action is provided by concrete surrounding the bottom steel flange. It is assumed that the first stage concrete (c1) has reached a specified compressive strength. The same section is used for the load case, considering the self-weight of the simply supported beam and a fresh (unhardened) second stage concrete (concrete slab c2.)

Table 4 shows the properties of the steel and concrete 1 section transformed at $\mathrm{t}=3$-day.

Table 4. Steel and concrete $c 1$ transformed section at $\mathrm{t}=3$-day.

\begin{tabular}{|c|c|c|c|c|c|c|}
\hline \multicolumn{6}{|c|}{ Section : Steel and Concrete 1 at $t=3$-day; $n=$} & \multirow{2}{*}{\begin{tabular}{|r}
8.762 \\
(Area) (di)
\end{tabular}} \\
\hline \multirow{2}{*}{ Section } & Area & Yi & $($ Area)(Yi) & I & di & \\
\hline & $\mathrm{cm}^{2}$ & $\mathrm{~cm}$ & $\mathrm{~cm}^{3}$ & $\mathrm{~cm}^{4}$ & $\mathrm{~cm}$ & $\mathrm{~cm}^{4}$ \\
\hline Steel & $1,396.6$ & 58.6 & $81,792.9$ & $3,690,893.4$ & -12.06 & 203,120 \\
\hline \multirow[t]{2}{*}{ Concrete c1 } & 450.7 & 108.0 & $48,671.7$ & $67,849.0$ & 37.37 & 629,448 \\
\hline & 1,847 & & 130,465 & $3,758,742$ & & 832,569 \\
\hline
\end{tabular}

The section moduli for steel and concrete $\mathrm{cl}$ at $\mathrm{t}=3$-day, referenced from the extreme steel and bottom concrete surfaces, are

$$
\begin{gathered}
\mathrm{Sx}_{3}=\frac{\mathrm{I}^{\prime} \mathrm{x}_{2}}{\mathrm{y}_{\mathrm{b} 2}^{\prime}}=\frac{4,591,311 \mathrm{~cm}^{4}}{45.37 \mathrm{~cm}}=101,191 \mathrm{~cm}^{3} \\
\mathrm{Sx}_{4}=\frac{\mathrm{I}^{\prime} \mathrm{x}_{2}}{\mathrm{y}_{\mathrm{t} 2}^{\prime}}=\frac{4,591,311 \mathrm{~cm}^{4}}{70.63 \mathrm{~cm}}=65,008 \mathrm{~cm}^{3} \\
\mathrm{Sx}_{9}=\frac{\mathrm{I}^{\prime} \mathrm{x}_{2}}{\mathrm{y}_{\mathrm{b} 4}^{\prime}} \times \mathrm{n}_{3}=\frac{4,591,311 \mathrm{~cm}^{4}}{57.37 \mathrm{~cm}} \times 8.762=701,189 \mathrm{~cm}^{3}
\end{gathered}
$$

where:

$\mathrm{Sx}_{3}=$ section modulus of transformed steel section with respect to the extreme bottom steel surface.

$\mathrm{Sx}_{4}=$ section modulus of transformed steel section with respect to the extreme top steel surface. 


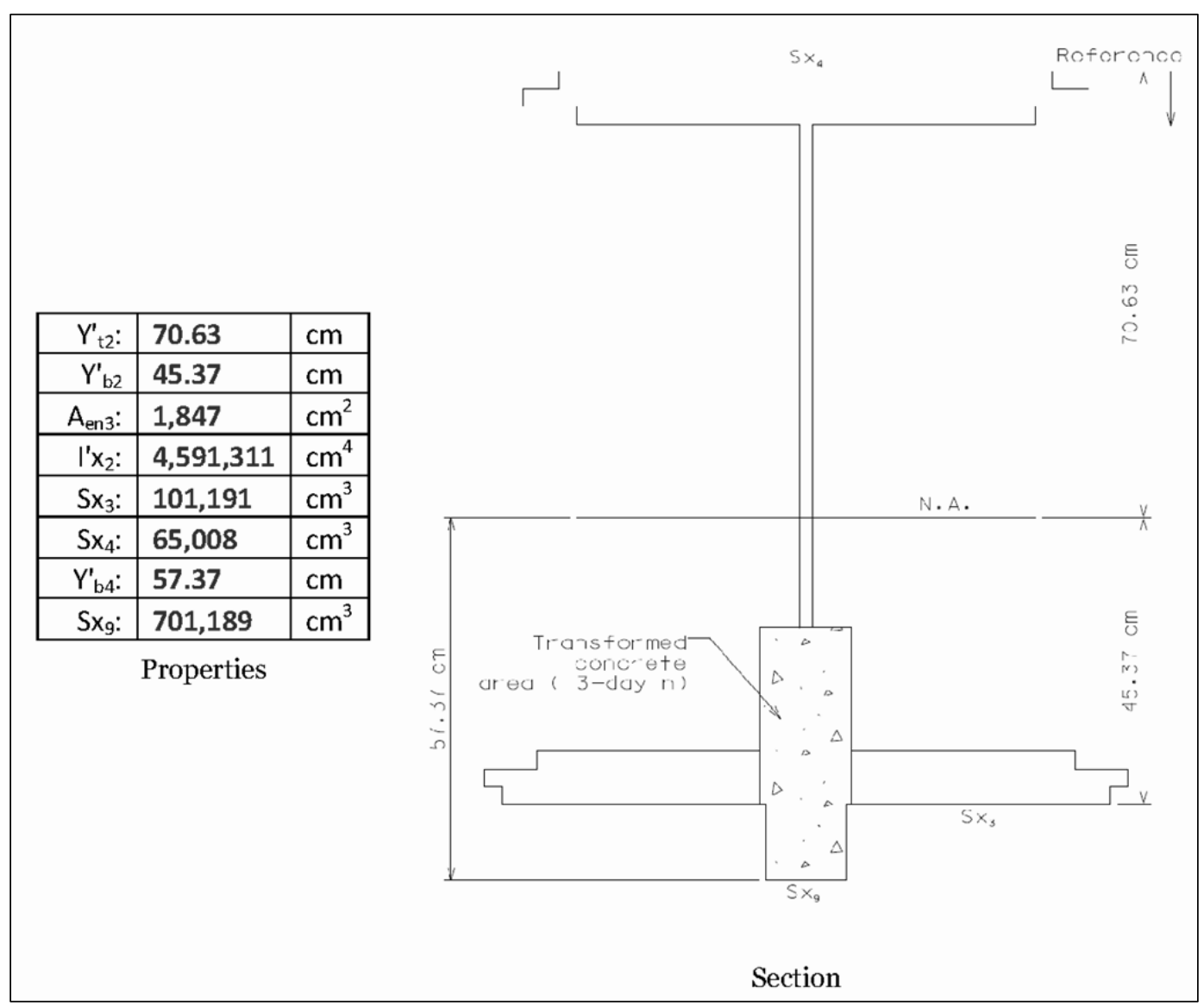

Figure 9. Properties of steel and concrete $\mathrm{c} 1$ transformed section at $\mathrm{t}=3$-day.

Sxy $=$ section modulus of transformed concrete section with respect to the extreme bottom concrete $\mathrm{c} 1$ surface.

$\mathrm{I}^{\prime} \mathrm{x}_{2}=$ moment of inertia of transformed pre-flex beam taking into account the steel beam and concrete encasing its bottom flange after three days.

$A_{\text {en3 }}=$ area of transformed pre-flex beam taking into account the steel beam and concrete encasing its bottom flange after three days.

$\mathrm{y}^{\prime}{ }_{\mathrm{b} 2}=$ distance from the neutral axis to the extreme bottom steel surface.

$\mathrm{y}^{\prime} \mathrm{t}_{2}=$ distance from the neutral axis to the extreme top steel surface.

$\mathrm{y}^{\prime}{ }^{\prime} 4=$ distance from the neutral axis to the extreme bottom concrete c1 surface.

$\mathrm{n}_{3}=$ modular ratio at $\mathrm{t}=3$-day: $\mathrm{n}_{3}=\frac{\mathrm{E}_{\mathrm{s}}}{\mathrm{E}_{\mathrm{c} 3}}=\frac{201.105 \mathrm{GPa}}{22.951 \mathrm{GPa}}=8.762$

$E_{\mathrm{s}}=$ modulus of elasticity of steel $=201.105 \mathrm{GPa}$.

$\mathrm{E}_{\mathrm{c} 3}=$ modulus of elasticity of concrete after three days $=22.951 \mathrm{GPa}$. 


\section{Concrete $c 1$ at $t>28-d a y$}

Table 5 shows the properties of the steel and concrete c1 section transformed at $\mathrm{t}>28$-day.

Table 5. Steel and concrete $c 1$ transformed section at $t>28$-day.

\begin{tabular}{|c|c|c|c|c|c|c|}
\hline \multicolumn{6}{|c|}{ Section: Steel and Concrete 1 at $t>28$-day; $n=$} & 5.542 \\
\hline \multirow{2}{*}{ Section } & Area & Yi & (Area)(Yi) & 1 & di & (Area) $(\mathrm{di})^{2}$ \\
\hline & $\mathrm{cm}^{2}$ & $\mathrm{~cm}$ & $\mathrm{~cm}^{3}$ & $\mathrm{~cm}^{4}$ & $\mathrm{~cm}$ & $\mathrm{~cm}^{4}$ \\
\hline Steel & $1,396.6$ & 58.6 & $81,792.9$ & $3,690,893.4$ & -16.70 & 389,480 \\
\hline \multirow[t]{2}{*}{ Concrete $\mathrm{c} 1$} & 712.5 & 108.0 & $76,950.9$ & $107,270.4$ & 32.73 & 763,405 \\
\hline & 2,109 & & 158,744 & $3,798,164$ & & $1,152,885$ \\
\hline
\end{tabular}

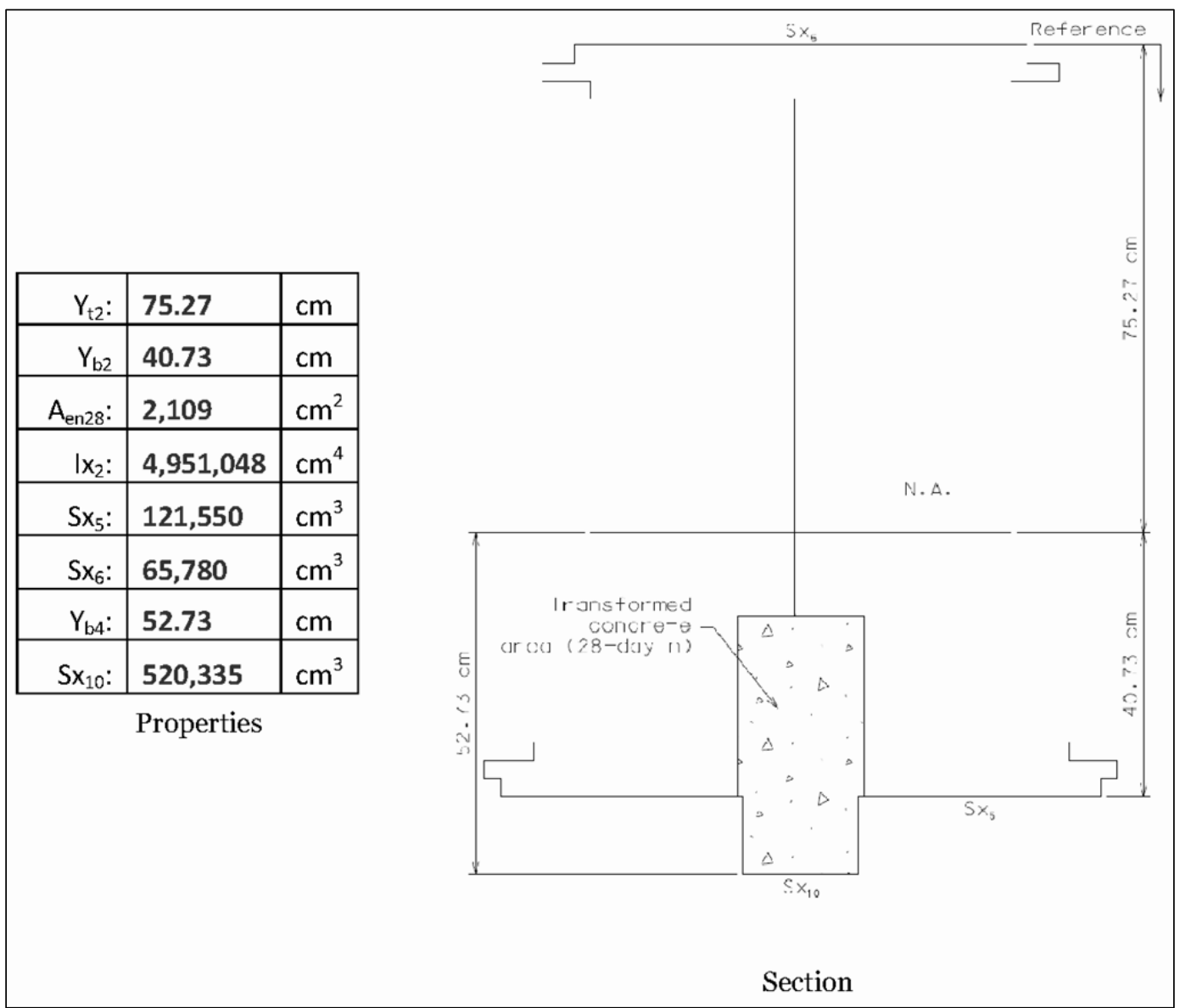

Figure 10. Properties of steel and concrete $c 1$ transformed section at $t>28$-day.

The section moduli for steel and concrete c1 at t > 28-day, referenced from the extreme steel and bottom concrete surfaces are: 


$$
\begin{gathered}
\mathrm{Sx}_{5}=\frac{\mathrm{Ix}_{2}}{\mathrm{y}_{\mathrm{b} 2}}=\frac{4,951,048 \mathrm{~cm}^{4}}{40.73 \mathrm{~cm}}=121,550 \mathrm{~cm}^{3} \\
\mathrm{Sx}_{6}=\frac{\mathrm{Ix}_{2}}{\mathrm{y}_{\mathrm{t} 2}}=\frac{4,951,048 \mathrm{~cm}^{4}}{75.27 \mathrm{~cm}}=65,780 \mathrm{~cm}^{3} \\
\mathrm{Sx}_{10}=\frac{\mathrm{Ix}_{2}}{\mathrm{y}_{\mathrm{b} 4}} \times \mathrm{n}_{28}=\frac{4,591,311 \mathrm{~cm}^{4}}{52.73 \mathrm{~cm}} \times 5.542=520,335 \mathrm{~cm}^{3}
\end{gathered}
$$

where:

$\mathrm{Sx}_{5}=$ section modulus of transformed steel section with respect to the extreme bottom steel surface.

$\mathrm{Sx}_{6}=$ section modulus of transformed steel section with respect to the extreme top steel surface.

$\mathrm{Sx}_{10}=$ section modulus of transformed concrete section with respect to the extreme bottom concrete 1 surface.

$\mathrm{I}_{\mathrm{X} 2}=$ moment of inertia of transformed pre-flex beam taking into account the steel beam and concrete encasing its bottom flange after 28 days.

$\mathrm{A}_{\text {en28 }}=$ area of transformed pre-flex beam taking into account the steel beam and concrete encasing its bottom flange after 28 days.

$\mathrm{y}_{\mathrm{b} 2}=$ distance from the neutral axis to the extreme bottom steel surface.

$\mathrm{y}_{\mathrm{t} 2}=$ distance from the neutral axis to the extreme top steel surface.

$\mathrm{yb}_{\mathrm{b} 4}=$ distance from the neutral axis to the extreme bottom concrete c1 surface.

$\mathrm{n}_{28}=$ modular ratio at $\mathrm{t}>28$-day:

$$
\mathrm{n}_{28}=\frac{\mathrm{E}_{\mathrm{s}}}{\mathrm{E}_{\mathrm{c} 28}}=\frac{201.105 \mathrm{GPa}}{36.289 \mathrm{GPa}}=5.542
$$

$\mathrm{E}_{\mathrm{c} 28}=$ modulus of elasticity of concrete after 28 days $=36.289 \mathrm{GPa}$.

\section{Concrete $c 1$ and $c 2$ at $t>28$-day (fully composite)}

Once concrete hardens, an additional composite action comprising the steel girder (including steel plates), the first stage concrete (concrete $\mathrm{cl}$ at bottom flange), and the second stage concrete (top concrete c2) is assumed. 
Table 6 shows the properties of the steel, concrete c1, and concrete c2 (slab) section transformed at $\mathrm{t}>28$-day.

Table 6. Steel and both concretes ( $c 1$ and $c 2$ ) transformed section at $t>28$-day.

\begin{tabular}{|c|l|l|l|l|l|l|}
\hline \multicolumn{6}{|c|}{ Section: Steel, Concrete 1, and Concrete 2 at $\mathrm{t}>$ 28-day; $\mathrm{n}=$} & \multicolumn{1}{c|}{5.542} \\
\hline \multirow{2}{*}{ Section } & Area & Yi & (Area)(Yi) & I & di & (Area) (di) \\
\cline { 2 - 8 } & $\mathrm{cm}^{2}$ & $\mathrm{~cm}$ & $\mathrm{~cm}^{3}$ & $\mathrm{~cm}^{4}$ & $\mathrm{~cm}$ & $\mathrm{~cm}^{4}$ \\
\hline Pre-flex & $2,109.1$ & 87.27 & $184,052.6$ & $4,951,048.3$ & 27.75 & $1,623,586$ \\
\hline Concrete c2 & $1,335.9$ & 15.72 & $20,999.7$ & $151,513.1$ & -43.80 & $2,563,200$ \\
\hline & 3,445 & & 205,052 & $5,102,561$ & & $4,186,787$ \\
\hline
\end{tabular}

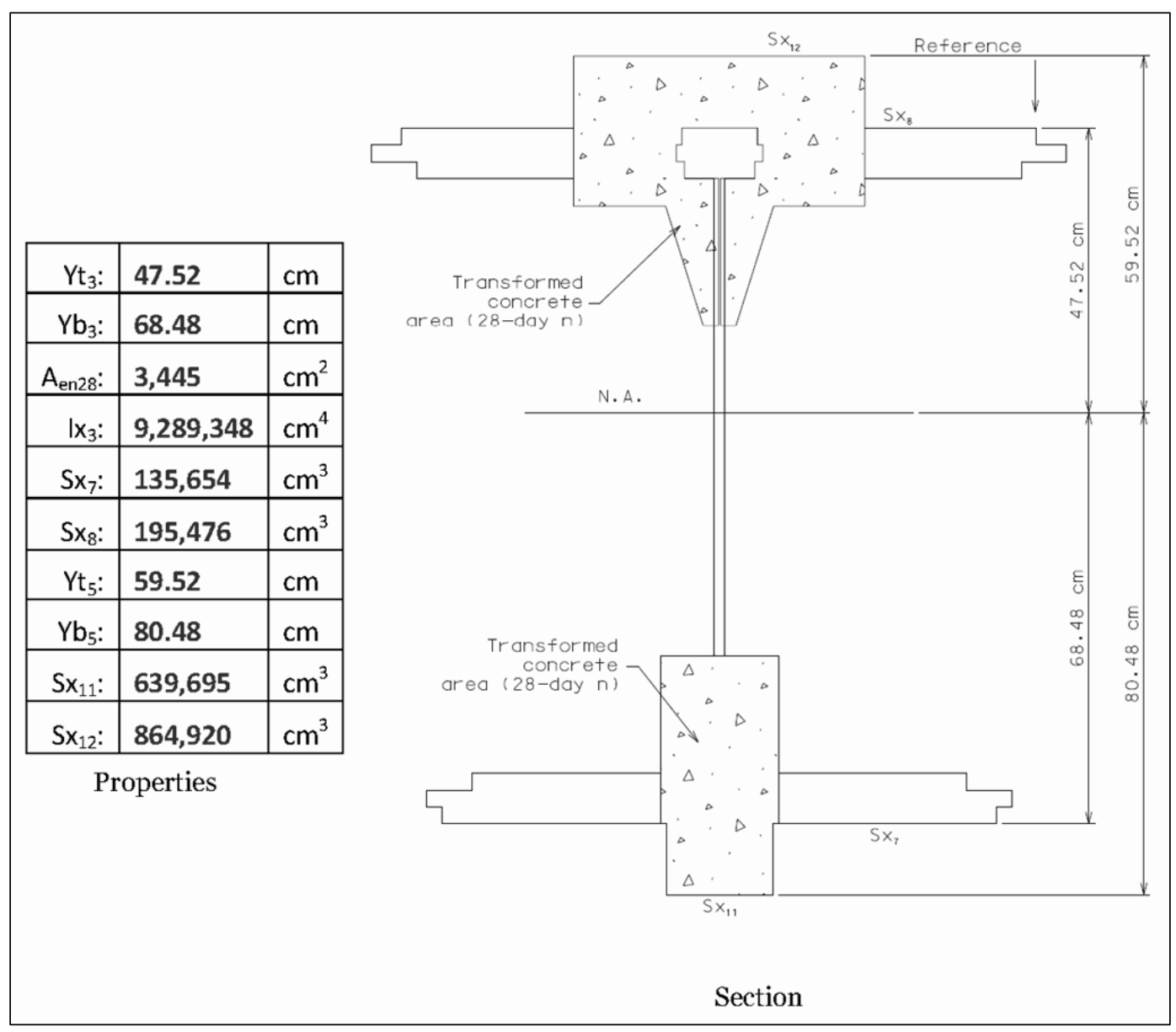

Figure 11. Properties of steel and both concretes (c1 and $c 2$ ) transformed section at $t>28$ day.

The section moduli for steel, concretes c1, and c2 at t $>28$-day are computed next. 


$$
\begin{gathered}
\mathrm{Sx}_{7}=\frac{\mathrm{Ix}_{3}}{\mathrm{y}_{\mathrm{b} 3}}=\frac{9,289,348 \mathrm{~cm}^{4}}{68.48 \mathrm{~cm}}=135,654 \mathrm{~cm}^{3} \\
\mathrm{Sx}_{8}=\frac{\mathrm{Ix}_{3}}{\mathrm{y}_{\mathrm{t} 3}}=\frac{9,289,348 \mathrm{~cm}^{4}}{47.52 \mathrm{~cm}}=195,476 \mathrm{~cm}^{3} \\
\mathrm{Sx}_{11}=\frac{\mathrm{Ix}_{3}}{\mathrm{y}_{\mathrm{b} 5}} \times \mathrm{n}_{28}=\frac{9,289,348 \mathrm{~cm}^{4}}{80.48 \mathrm{~cm}} \times 5.542=639,695 \mathrm{~cm}^{3} \\
\mathrm{Sx}_{12}=\frac{\mathrm{Ix}_{3}}{\mathrm{y}_{\mathrm{t} 5}} \times \mathrm{n}_{28}=\frac{9,289,348 \mathrm{~cm}^{4}}{59.52 \mathrm{~cm}} \times 5.542=864,920 \mathrm{~cm}^{3}
\end{gathered}
$$

where:

$\mathrm{Sx}_{7}=$ section modulus of transformed steel section with respect to the extreme bottom steel surface

$\mathrm{Sx}_{8}=$ section modulus of transformed steel section with respect to the extreme top steel surface

$\mathrm{Sx}_{11}=$ section modulus of transformed concrete section with respect to the extreme bottom concrete $\mathrm{c} 1$ surface

$\mathrm{Sx}_{12}=$ section modulus of transformed concrete section with respect to the extreme top concrete $\mathrm{c} 2$ surface

$\mathrm{Ix}_{3}=$ moment of inertia of transformed pre-flex beam and slab concrete $\mathrm{c} 2$ after 28 days

$\mathrm{A}_{\mathrm{en} 28}=$ area of transformed pre-flex beam and concrete slab after 28 days

$\mathrm{y}_{\mathrm{b} 3}=$ distance from the neutral axis to the extreme bottom steel surface

$\mathrm{y}_{\mathrm{t} 3}=$ distance from the neutral axis to the extreme top steel surface

$\mathrm{yb}_{\mathrm{b} 5}=$ distance from the neutral axis to the extreme bottom concrete c1 surface

$\mathrm{y}_{\mathrm{t} 5}=$ distance from the neutral axis to the extreme top concrete $\mathrm{c} 2$ surface

$\mathrm{n}_{28}=$ modular ratio at $\mathrm{t}>28$-day: 5.542 


\section{Analysis of Pre-flex Beams}

\section{Dead load analysis of components and attachments}

The dead load and superimposed dead loads of the superstructure are steel girder self weight, diaphragms, concrete encasing bottom flange (c1), concrete slab on top flange of steel (c2), concrete encasing steel web (c3), parapets, wearing surface, and additional weight (luminaries, piping, etc.). See Figure 4 and 5 for member details. The values associated with such loads are presented next. Depending on the stage of loading, different load combinations are considered during the analysis or design of a pre-flex composite system.

1. Girder self-weight, $w_{g}$ :

$$
\begin{aligned}
& \gamma_{\mathrm{s}}=\text { steel unit weight }=76,518 \mathrm{~N} / \mathrm{m}^{3} \\
& A_{\mathrm{s}}=\text { area of steel girder and plates }=1,397 \mathrm{~cm}^{2} \\
& \mathrm{w}_{\mathrm{g}}=\gamma_{\mathrm{s}} \times \mathrm{A}_{\mathrm{s}}=76,518 \mathrm{~N} / \mathrm{m}^{3} \times 1,397 \mathrm{~cm}^{2}=10,686 \mathrm{~N} / \mathrm{m}
\end{aligned}
$$

2. Bottom concrete, $w_{c 1}$ :

$$
\begin{aligned}
\gamma_{c} & =\text { concrete unit weight }=23,544 \mathrm{~N} / \mathrm{m}^{3} \\
A_{\mathrm{c} 1} & =\text { area of bottom concrete }=3,949 \mathrm{~cm}^{2} \\
\mathrm{w}_{\mathrm{c} 1} & =\gamma_{\mathrm{c}} \times \mathrm{A}_{\mathrm{c} 1}=23,544 \mathrm{~N} / \mathrm{m}^{3} \times 3,949 \mathrm{~cm}^{2}=9,297 \mathrm{~N} / \mathrm{m}
\end{aligned}
$$

3. Diaphragms, $w_{d p h}$. Assume four diaphragms (one at each end, one at the one-third span, and one at the two-thirds span):

$$
\begin{aligned}
A_{D} & =\text { area of diaphragm }=1.73 \mathrm{~m}^{2} \\
t_{D} & =\text { thickness of diaphragm }=0.30 \mathrm{~m} \\
n_{g} & =\text { number of girders }=5 \\
L & =\text { bridge span }=39.4 \mathrm{~m} \\
\mathrm{w}_{\mathrm{dph}} & =\frac{12 \times \mathrm{A}_{\mathrm{D}} \times \mathrm{t}_{\mathrm{D}} \times \gamma_{\mathrm{c}}}{\mathrm{n}_{\mathrm{g}} \times \mathrm{L}}=\frac{12 \times 1.73 \mathrm{~m}^{2} \times 0.30 \mathrm{~m} \times 23,544 \mathrm{~N} / \mathrm{m}^{3}}{5 \times 39.4 \mathrm{~m}}=744 \mathrm{~N} / \mathrm{m}
\end{aligned}
$$

4. Concrete slab on top flange of steel girder, $w_{\mathrm{c} 2}$ : 


$$
\begin{aligned}
A_{C 2} & =7,404 \mathrm{~cm}^{2} \\
\mathrm{w}_{\mathrm{c} 2} & =\gamma_{\mathrm{c}} \times \mathrm{A}_{\mathrm{c} 2}=23,544 \mathrm{~N} / \mathrm{m}^{3} \times 7,404 \mathrm{~cm}^{2}=17,431 \mathrm{~N} / \mathrm{m}
\end{aligned}
$$

5. Concrete encasing steel girder web, $w_{c 3}$ :

$$
\begin{aligned}
& \mathrm{A}_{\mathrm{C}_{3}}=550 \mathrm{~mm} \times 300 \mathrm{~mm}=1,650 \mathrm{~cm}^{2} \\
& \mathrm{w}_{\mathrm{c} 3}=\gamma_{\mathrm{c}} \times \mathrm{A}_{\mathrm{c} 3}=23,544 \mathrm{~N} / \mathrm{m}^{3} \times 1,650 \mathrm{~cm}^{2}=3,885 \mathrm{~N} / \mathrm{m}
\end{aligned}
$$

6. Parapets, $w_{p}$. A parapet $1.18 \mathrm{~m}$ (tall) by $0.46 \mathrm{~m}$ (thick) is considered in this bridge. The total weight of parapets is divided by the number of beams:

$$
\mathrm{w}_{\mathrm{p}}=\frac{2 \times \gamma_{\mathrm{c}} \times \mathrm{A}_{\mathrm{p}}}{\mathrm{n}_{\mathrm{g}}}=\frac{2}{5} \times 23,544 \mathrm{~N} / \mathrm{m}^{3} \times(1.18 \times 0.46) \mathrm{m}^{2}=5,112 \mathrm{~N} / \mathrm{m}
$$

7. Wearing surface, $w_{W s:}$

$$
\begin{aligned}
\gamma_{w s} & =\text { unit weight of wearing surface }=23,054 \mathrm{~N} / \mathrm{m}^{3} \\
t_{w s} & =\text { thickness of wearing surface }=80 \mathrm{~mm} \\
\mathrm{~T}_{\mathrm{way}} & =\text { travelway }=11.96 \mathrm{~m} \\
\mathrm{w}_{\mathrm{ws}} & =\frac{\gamma_{\mathrm{ws}} \times \mathrm{t}_{\mathrm{ws}} \times \mathrm{T}_{\text {way }}}{\mathrm{n}_{\mathrm{g}}}=\frac{23,054 \mathrm{~N} / \mathrm{m}^{3} \times 80 \mathrm{~mm} \times 11.96 \mathrm{~m}}{5}=4,412 \mathrm{~N} / \mathrm{m}
\end{aligned}
$$

8. Additional superimposed loads, $w_{A S L}$. The additional weight provided by posts, piping, etc. was assumed as one-fifth of $\mathrm{w}_{\mathrm{ws}}$ :

$$
\mathrm{w}_{\mathrm{ASL}}=\frac{1}{5} \times 4,412 \mathrm{~N} / \mathrm{m}=882 \mathrm{~N} / \mathrm{m}
$$

The shear forces, produced by dead and superimposed dead loads, at the end of the simply-supported beam are

$$
\mathrm{V}_{\mathrm{Di}}=\mathrm{w}_{\mathrm{i}} \times \mathrm{L} / 2
$$

where $w_{i}$ varies depending on the type of load: 


$$
\begin{aligned}
& \mathrm{V}_{\text {Dg }}=10,686 \mathrm{~N} / \mathrm{m} \times \frac{39.4 \mathrm{~m}}{2}=210,518 \mathrm{~N} \\
& \mathrm{~V}_{\text {Dc1 }}=9,297 \mathrm{~N} / \mathrm{m} \times \frac{39.4 \mathrm{~m}}{2}=183,148 \mathrm{~N} \\
& \mathrm{~V}_{\text {Ddph }}=744 \mathrm{~N} / \mathrm{m} \times \frac{39.4 \mathrm{~m}}{2}=14,663 \mathrm{~N} \\
& \mathrm{~V}_{\text {Dc2 }}=17,431 \mathrm{~N} / \mathrm{m} \times \frac{39.4 \mathrm{~m}}{2}=343,397 \mathrm{~N} \\
& \mathrm{~V}_{\text {Dc3 }}=3,885 \mathrm{~N} / \mathrm{m} \times \frac{39.4 \mathrm{~m}}{2}=76,530 \mathrm{~N} \\
& \mathrm{~V}_{\text {Dp }}=5,112 \mathrm{~N} / \mathrm{m} \times \frac{39.4 \mathrm{~m}}{2}=100,704 \mathrm{~N} \\
& \mathrm{~V}_{\text {Dgs }}=4,412 \mathrm{~N} / \mathrm{m} \times \frac{39.4 \mathrm{~m}}{2}=86,907 \mathrm{~N} \\
& \mathrm{~V}_{\text {DASL }}=882 \mathrm{~N} / \mathrm{m} \times \frac{39.4 \mathrm{~m}}{2}=17,381 \mathrm{~N}
\end{aligned}
$$

\section{Live load analysis}

The design live load for the ASD (Allowable Stress Design) and LFD (Load Factor Design) approach is taken as the governing load condition between the HS20-44 wheel load (Figure 12) and the $640 \mathrm{lb} / \mathrm{ft}$ lane load (Figure 13) with an 18-kip concentrated load for moment and a 26-kip concentrated load for shear, as defined in American Association of State Highway and Transportation Official's (AASHTO) Standard specifications for highway bridges (SSHB), Article 3.7 (AASHTO 2002).

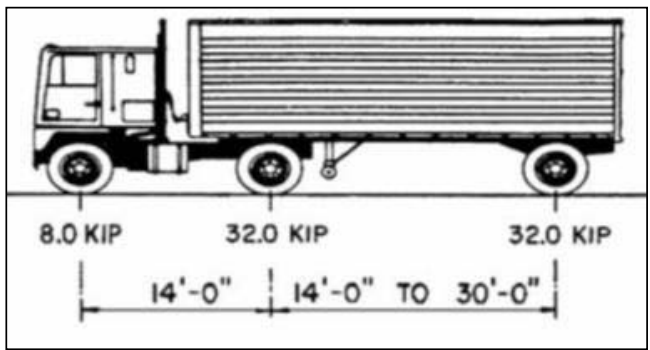

Figure 12. Design truck HS20-44.

Uniform Load of $0.640 \mathrm{k} / \mathrm{ft}$

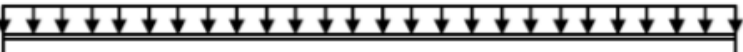

Figure 13. Lane loading. 


\section{Live load distribution factor for flexural moment $\left(g_{m}\right)$}

Article 3.23 (Table 3.23.1) from AASHTO SSHB defines the moment distribution factor for one traffic lane supported on longitudinal steel girders by the following expression:

$$
\mathrm{g}_{\mathrm{m} 1}=\frac{\mathrm{S}}{7.0}=\frac{8.86 \mathrm{ft}}{7.0}=1.2657
$$

where:

$$
\mathrm{S}=\text { average stringer spacing in feet }
$$

For two or more traffic lanes, the expression for the distribution factor may be determined by the formula

$$
\mathrm{g}_{\mathrm{m} 2}=\frac{\mathrm{S}}{5.5}=\frac{8.86 \mathrm{ft}}{5.5}=\underline{\mathbf{1 . 6 1 0 9}} \text { (governs!) }
$$

\section{Live load distribution factor for shear (gv)}

The lever rule method is applied to determine the distribution factors for shear, as shown in Figures 14 and 15 for one-lane and two or more lanes, respectively.

$$
\begin{gathered}
\sum \mathrm{M}_{\mathrm{C}}=8.86 \mathrm{P}+\mathrm{P}(8.86-6.00)-8.86 \mathrm{R}_{\mathrm{B}}=0 \\
\mathrm{R}_{\mathrm{B}}=\frac{\mathrm{P}(8.86+2.86)}{8.86}=1.3228 \mathrm{P} \\
\mathrm{g}_{\mathrm{v} 1}=1.3228
\end{gathered}
$$

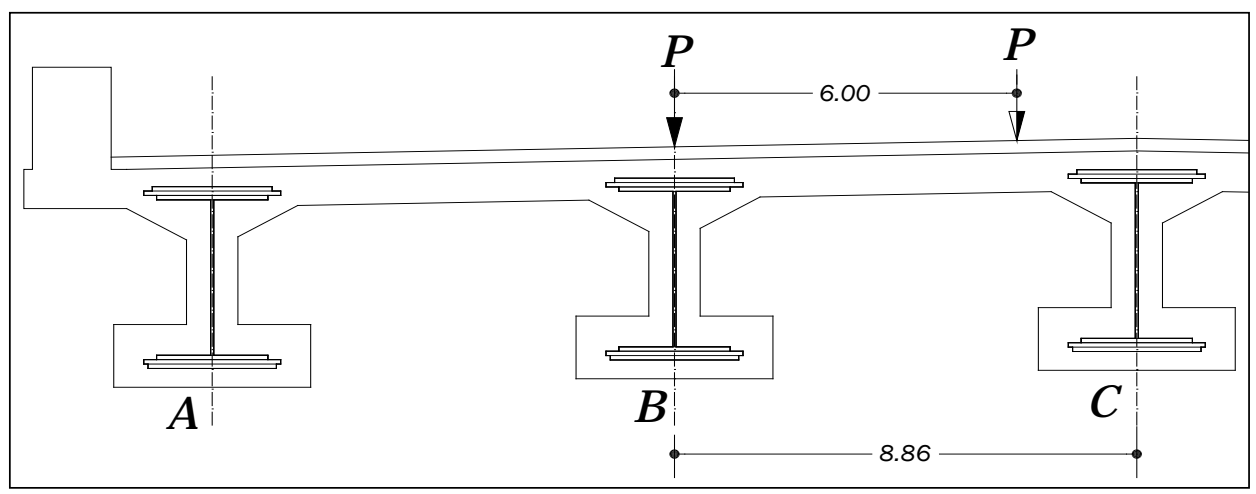

Figure 14. Application of lever rule method for one-lane. 


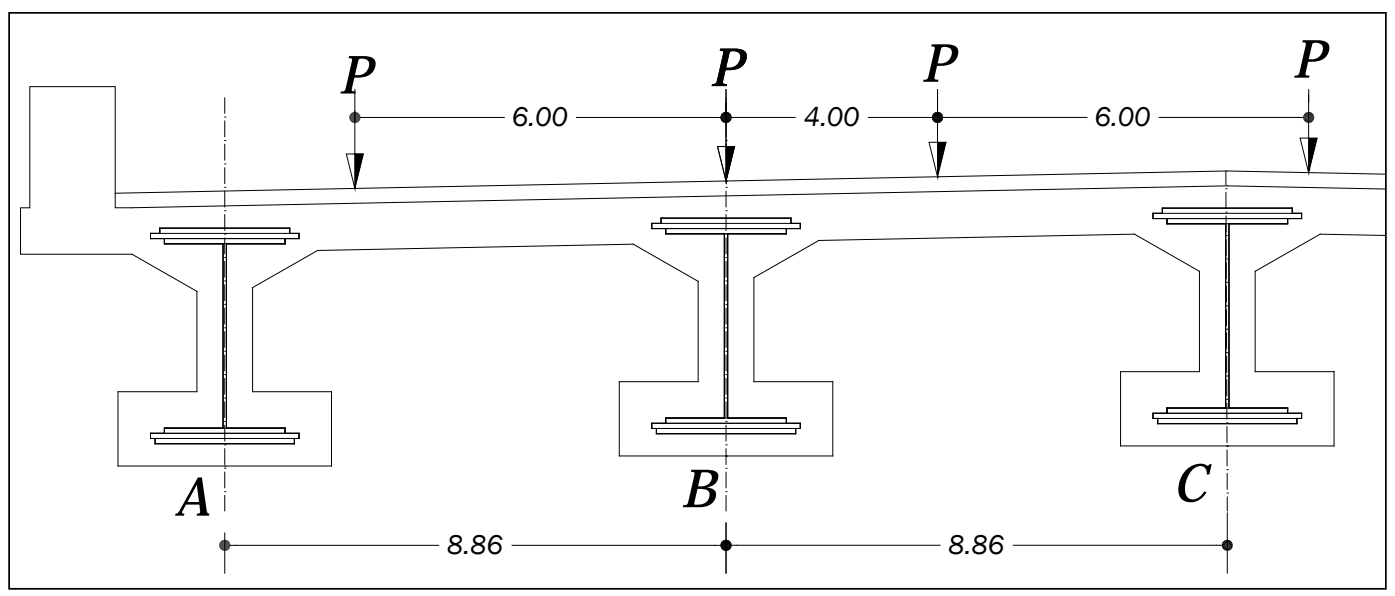

Figure 15. Application of lever rule method for two-lane.

$$
\begin{gathered}
\sum \mathrm{M}_{\mathrm{A}}=0=\mathrm{P}(8.66-6.00)-8.86 \mathrm{R}_{\mathrm{B} \text { Left }} \\
\mathrm{R}_{\mathrm{B} \text { Left }}=\frac{2.86 \mathrm{P}}{8.86}=0.3228 \mathrm{P} \\
\mathrm{DF}_{\text {Left }}=0.3228 \\
\sum \mathrm{M}_{\mathrm{c}}=0=\mathrm{P}(8.86)+\mathrm{P}(8.86-4.00)-\mathrm{R}_{\mathrm{B} \mathrm{Right}}(8.86) \\
\mathrm{R}_{\mathrm{BR} \text { Right }}=\mathrm{P}\left(\frac{8.86+4.86}{8.86}\right)=1.5485 \mathrm{P} \\
\mathrm{DF}_{\text {Right }}=1.5485 \\
\mathrm{~g}_{\mathrm{v} 2}=\mathrm{DF}_{\text {Left }}+\mathrm{DF} F_{\text {Right }}=0.3228+1.5485=1.8713 \\
\mathrm{~g}_{\mathrm{v} 1}=1.3228 \\
\mathrm{~g}_{\mathrm{v} 2}=\underline{\mathbf{1 . 8 7 1 3}} \text { (governs!) }
\end{gathered}
$$

\section{Live load moment}

Standard truck loading (refer to Appendix A, AASHTO SSHB, 2002) governs, and the wheel line moment for a $39.4-\mathrm{m}$ span (129-ft) is

$$
\mathrm{M}_{\mathrm{HS} 20}=1,032 \mathrm{k}-\mathrm{ft}
$$


Based on SSHB, Article 3.8.2, the impact increment is expressed as a fraction of the live load stress and is computed as follows:

$$
I=\left(\frac{50}{L+125}\right)=\left(\frac{50}{129.3 \mathrm{ft}+125}\right) \times 100 \%=20 \% \leq 30 \%
$$

The truck loading shall be incremented by the impact factor. This dynamic factor shall not be applied when lane load condition controls.

$$
\mathrm{M}_{(\mathrm{HS} 20+\mathrm{IM})}=1,032 \mathrm{k}-\mathrm{ft} \times 1.20=1,238 \mathrm{k}-\mathrm{ft}
$$

The distributed live load moment is

$$
\begin{gathered}
\mathrm{M}_{(\mathrm{HS} 20+\mathrm{IM})}=1,238 \mathrm{k}-\mathrm{ft} \times \mathrm{g}_{\mathrm{m}}=1,238 \mathrm{k}-\mathrm{ft} \times 1.6109=1,995 \mathrm{k}-\mathrm{ft} \\
\mathrm{M}_{(\mathrm{HS} 20+\mathrm{IM})}=2,705,000 \mathrm{~N}-\mathrm{m}
\end{gathered}
$$

Similarly, for legal loads the maximum live load moments are

$$
\begin{aligned}
& \mathrm{M}_{\text {(Type 3+IM) }}=1,911,000 \mathrm{~N}-\mathrm{m} \\
& \mathrm{M}_{(\text {Type 3S2+IM) }}=2,424,000 \mathrm{~N}-\mathrm{m} \\
& \mathrm{M}_{\text {(Type 3-3+IM) }}=2,496,000 \mathrm{~N}-\mathrm{m}
\end{aligned}
$$

\section{Live load shear}

From Appendix A, AASHTO SSHB, the wheel line shear for a 39.4-m span (129.3 ft) is governed by lane loading and is

$$
\mathrm{V}_{\mathrm{HS} 20}=33.8 \mathrm{k}
$$

The truck loading shall also be incremented by the impact factor (20\%), resulting in

$$
\mathrm{V}_{\mathrm{HS} 20+\mathrm{IM}}=33.8 \mathrm{k} \times 1.20=40.6 \mathrm{k}
$$

The distributed shear is

$$
\mathrm{V}_{(\mathrm{HS} 20+\mathrm{IM})}=40.6 \mathrm{k} \times \mathrm{g}_{\mathrm{v}}=40.6 \mathrm{k} \times 1.8713=76.0 \mathrm{k}
$$




$$
\mathrm{V}_{(\mathrm{HS} 20+\mathrm{IM})}=338,100 \mathrm{~N}
$$

Similarly, for legal loads the maximum shear loads are

$$
\begin{aligned}
& \mathrm{V}_{(\text {Type3+IM) }}=234,700 \mathrm{~N} \\
& \mathrm{~V}_{\text {(Type 3S2+IM) }}=306,900 \mathrm{~N} \\
& \mathrm{~V}_{(\text {Type3-3+IM) }}=322,300 \mathrm{~N}
\end{aligned}
$$




\section{Stress Calculations}

The stress analysis is divided into the following loading stages:

1. Stage 1: Pre-flex loading

2. Stage 2: Release of load and self-weight of steel girder and bottom concrete (c1)

3. Stage 3: Additional loads due to concrete slab concrete (c2), diaphragms, and concrete encasing the steel web (c3)

4. Stage 4: Additional weight due to superimposed loads on concrete slab

\section{Stage 1: Pre-flex load}

The first load case considers the pre-flexion of the steel beam. The beam is assumed in a simply supported condition with two point loads located at quarter points of its span (see Figure 16). The loads are calculated based on an allowable stress of the steel girder. The maximum allowable moment and pre-flexion loads are computed using Equations 2 and 3:

$$
\begin{aligned}
& M_{\text {allow }}=f_{s} \times S x \\
& P_{\text {pf }}=\frac{4 \times M_{\text {allow }}}{L}
\end{aligned}
$$

where:

$$
\begin{aligned}
\text { Mallow } & =\text { maximum moment allowed } \\
\mathrm{P}_{\mathrm{pf}} & =\text { maximum pre-flexion load } \\
\mathrm{f}_{\mathrm{S}} & =\text { allowable stress in steel section } \\
\mathrm{Sx} & =\text { section modulus of steel section } \\
\mathrm{L} & =\text { span of member }
\end{aligned}
$$

This moment will produce a compressive stress at the top $\left(\mathrm{f}_{\mathrm{st}}\right)$ and a tension stress at the bottom $\left(f_{\mathrm{sb}}\right)$ of the steel girder as close as possible to the allowable stresses permitted. The pertinent section moduli were computed in Section 3. 


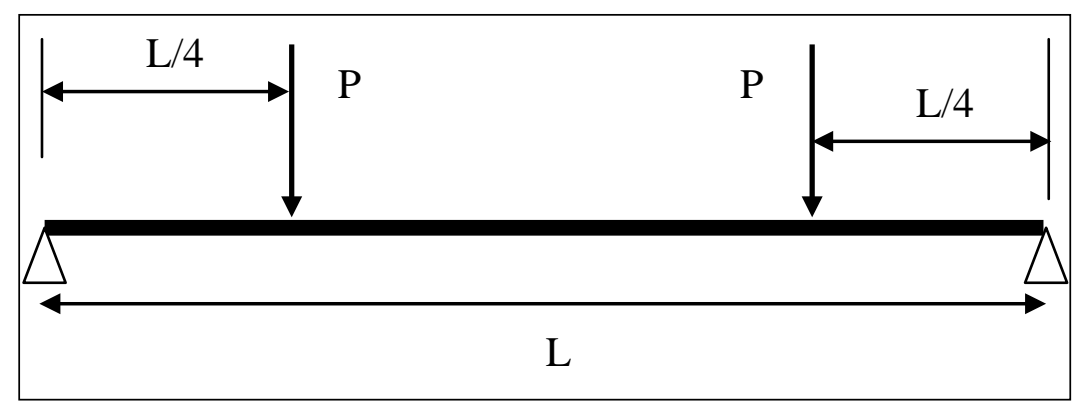

Figure 16. Point loads acting during the pre-flexion process.

For the example bridge:

$\mathrm{P}_{\mathrm{pf}}=$ Pre-flexion load $=1,459,000 \mathrm{~N}$

$\mathrm{M}_{\mathrm{pf}}=$ Pre-flexion moment $=\frac{\mathrm{P}_{\mathrm{pf}} \times \mathrm{L}}{4}$

$=\frac{1,459,000 \mathrm{~N} \times 39.4 \mathrm{~m}}{4}=14,372,000 \mathrm{~N}-\mathrm{m}$

$$
\begin{aligned}
& \mathrm{f}_{\mathrm{st}}=\frac{-\mathrm{M}_{\mathrm{p}} \mathrm{f}}{\mathrm{Sx_{2 }}}=\frac{-14,372,000 \mathrm{~N}-\mathrm{m}}{63,020 \mathrm{~cm}^{3}}=-22,806 \frac{\mathrm{N}}{\mathrm{cm}^{2}} \\
& \mathrm{f}_{\mathrm{sb}}=\frac{\mathrm{M}_{\mathrm{p}} \mathrm{f}}{\mathrm{Sx}_{1}}=\frac{-14,372,000 \mathrm{~N}-\mathrm{m}}{64,265 \mathrm{~cm}^{3}}=22,364 \frac{\mathrm{N}}{\mathrm{cm}^{2}} \\
& \mathrm{f}_{\mathrm{cb}}=\mathrm{N} / \mathrm{A} \\
& \mathrm{f}_{\mathrm{ct}}=\mathrm{N} / \mathrm{A}
\end{aligned}
$$

where:

$\mathrm{f}_{\text {st }}=$ stress at the extreme steel top fiber

$\mathrm{f}_{\mathrm{sb}}=$ stress at the extreme steel bottom fiber

$\mathrm{f}_{\mathrm{cb}}=$ stress at the extreme concrete bottom fiber

$\mathrm{f}_{\mathrm{ct}}=$ stress at the extreme concrete top fiber

Stress check:

$$
\begin{aligned}
& \mathrm{f}_{\text {st }}<\mathrm{f}_{\text {s allow }}: 22,806<24,720: . \text { OK } \\
& \mathrm{f}_{\mathrm{sb}}<\mathrm{f}_{\text {sallow }}: 22,364<24,720: . \text { OK }
\end{aligned}
$$


where:

$$
\begin{aligned}
& \mathrm{f}_{\mathrm{s} \text { allow }}=\Phi_{\text {sy }} \times \mathrm{f}_{\mathrm{y}}=0.8 \times 30,900 \mathrm{~N} / \mathrm{cm}^{2}=24,720 \mathrm{~N} / \mathrm{cm}^{2} \\
& \Phi_{\text {sy }}=0.8 \\
& \mathrm{f}_{\mathrm{y}}=30,900 \mathrm{~N} / \mathrm{cm}^{2}
\end{aligned}
$$

\section{Stage 2: Release and self-weight (steel and concrete c1)}

Once the steel girder is pre-deflected, the bottom flange (including the bottom cover plates) is encased with the first stage concrete (c1) and set in position until concrete reaches its specified compressive strength. Once c1 reaches its service strength $\left(0.4 \mathrm{f}_{\mathrm{C}}^{\prime}\right.$ at $\mathrm{t}=3$-day), the first composite action develops and the point loads are released. A recovery moment equal to the applied moment is assumed. New stresses in the top and bottom of the beam are computed.

In order to obtain the section modulus of the pre-flex beam, the new center of gravity and the moment of inertia of the composite section need to be calculated. The properties of the individual sections were discussed in Section 3.

For the example bridge, the stresses considered correspond to the following loads:

1. Release:

$$
\begin{aligned}
\mathrm{f}_{\mathrm{st}} & =\frac{\mathrm{M}_{\mathrm{pf}}}{\mathrm{Sx}}=\frac{14,372,000 \mathrm{~N}-\mathrm{m}}{65,008 \mathrm{~cm}^{3}}=22,108 \frac{\mathrm{N}}{\mathrm{cm}^{2}} \\
\mathrm{f}_{\mathrm{sb}} & =\frac{\mathrm{M}_{\mathrm{pf}}}{\mathrm{Sx}_{3}}=\frac{-14,372,000 \mathrm{~N}-\mathrm{m}}{101,191 \mathrm{~cm}^{3}}=-14,203 \frac{\mathrm{N}}{\mathrm{cm}^{2}} \\
\mathrm{f}_{\mathrm{cb}} & =\frac{\mathrm{M}_{\mathrm{pf}}}{\mathrm{Sx}}=\frac{-14,372,000 \mathrm{~N}-\mathrm{m}}{701,189 \mathrm{~cm}^{3}}=-2,050 \frac{\mathrm{N}}{\mathrm{cm}^{2}} \\
\mathrm{f}_{\mathrm{ct}} & =\mathrm{N} / \mathrm{A}
\end{aligned}
$$

2. Self-weight: 


$$
\begin{aligned}
& \mathrm{w}_{\mathrm{sw1}}=\mathrm{w}_{\mathrm{gs}}+\mathrm{w}_{\mathrm{c} 1}=(10,686+9,297) \mathrm{N} / \mathrm{m}=19,983 \mathrm{~N} / \mathrm{m} \\
& \mathrm{M}_{\mathrm{sw1}}=\frac{\mathrm{w}_{\mathrm{sw} 1} \times \mathrm{L}^{2}}{8}=\frac{19,983 \mathrm{~N} / \mathrm{m}^{2} \times(39.4 \mathrm{~m})^{2}}{8}=3,877,614 \mathrm{~N}-\mathrm{m} \\
& \mathrm{f}_{\mathrm{st}}=\frac{-\mathrm{M}_{\mathrm{sw} 1}}{\mathrm{Sx}}=\frac{-3,877,614 \mathrm{~N}-\mathrm{m}}{65,008 \mathrm{~cm}^{3}}=-5,965 \frac{\mathrm{N}}{\mathrm{cm}^{2}} \\
& \mathrm{f}_{\mathrm{sb}}=\frac{\mathrm{M}_{\mathrm{sw1}}}{\mathrm{Sx}_{3}}=\frac{3,877,614 \mathrm{~N}-\mathrm{m}}{101,191 \mathrm{~cm}^{3}}=3,832 \frac{\mathrm{N}}{\mathrm{cm}^{2}} \\
& \mathrm{f}_{\mathrm{cb}}=\frac{\mathrm{M}_{\mathrm{sw} 1}}{\mathrm{Sx}}=\frac{3,877,614 \mathrm{~N}-\mathrm{m}}{701,189 \mathrm{~cm}^{3}}=553 \frac{\mathrm{N}}{\mathrm{cm}^{2}} \\
& \mathrm{f}_{\mathrm{ct}}=\mathrm{N} / \mathrm{A}
\end{aligned}
$$

Stress check:

$$
\begin{gathered}
\mathrm{f}_{\mathrm{st}}=(-22,806+22,108-5,965) \frac{\mathrm{N}}{\mathrm{cm}^{2}}=-6,662 \frac{\mathrm{N}}{\mathrm{cm}^{2}} \\
\mathrm{f}_{\mathrm{sb}}=(22,364-14,203+3,832) \frac{\mathrm{N}}{\mathrm{cm}^{2}}=11,993 \frac{\mathrm{N}}{\mathrm{cm}^{2}} \\
f_{\mathrm{st}}<f_{\mathrm{s} \text { allow }}: 6,662<24,720: . \mathrm{OK} \\
f_{\mathrm{sb}}<f_{\mathrm{s} \text { allow }}: 11,993<24,720: . \mathrm{OK} \\
\mathrm{f}_{\mathrm{cb}}=(-2,05 \mathrm{O}+553) \frac{\mathrm{N}}{\mathrm{cm}^{2}}=-1,497 \frac{\mathrm{N}}{\mathrm{cm}^{2}} \\
f_{\mathrm{cb}}<f_{\mathrm{c} \text { allow }}: 1,497<2,060: . \mathrm{OK}
\end{gathered}
$$

where:

$$
\begin{aligned}
& \mathrm{f}_{\text {callow }}=\Phi_{\mathrm{c}} \times \mathrm{f}_{\mathrm{c}}=0.4 \times 5,150 \mathrm{~N} / \mathrm{cm}^{2}=2,060 \mathrm{~N} / \mathrm{cm}^{2} \\
& \Phi_{\mathrm{c}}=0.4 \\
& \mathrm{f}_{\mathrm{c}}=5,150 \mathrm{~N} / \mathrm{cm}^{2}
\end{aligned}
$$


Stage 3: Additional loads due to concrete slab (c2), diaphragms, and concrete encasing the steel web (c3)

After the beam is released, it is simply supported on the substructure. The concrete slab and diaphragms, including all formwork, are placed. These loads produce tension stress in the extreme bottom concrete fiber $\left(\mathrm{f}_{\mathrm{cb}}\right)$ and compression stress in the extreme steel top flange $\left(f_{\mathrm{st}}\right)$. For the example bridge, the stresses calculated are

1. Diaphragms:

$$
\begin{aligned}
& \mathrm{M}_{\mathrm{dph}}=\frac{\mathrm{W}_{\mathrm{dph}} \times \mathrm{L}^{2}}{8}=\frac{744 \mathrm{~N} / \mathrm{m} \times(39.4 \mathrm{~m})^{2}}{8}=144,433 \mathrm{~N}-\mathrm{m} \\
& \mathrm{f}_{\mathrm{st}}=\frac{-\mathrm{M}_{\mathrm{dph}}}{\mathrm{Sx}_{4}}=\frac{-144,433 \mathrm{~N}-\mathrm{m}}{65,008 \mathrm{~cm}^{3}}=-222 \frac{\mathrm{N}}{\mathrm{cm}^{2}} \\
& \mathrm{f}_{\mathrm{sb}}=\frac{\mathrm{M}_{\mathrm{dph}}}{\mathrm{Sx}}=\frac{144,433 \mathrm{~N}-\mathrm{m}}{101,191 \mathrm{~cm}^{3}}=143 \frac{\mathrm{N}}{\mathrm{cm}^{2}} \\
& \mathrm{f}_{\mathrm{cb}}=\frac{\mathrm{M}_{\mathrm{dph}}}{\mathrm{Sx}}=\frac{144,433 \mathrm{~N}-\mathrm{m}}{701,189 \mathrm{~cm}^{3}}=21 \frac{\mathrm{N}}{\mathrm{cm}^{2}} \\
& \mathrm{f}_{\mathrm{ct}}=\mathrm{N} / \mathrm{A}
\end{aligned}
$$

2. Concrete slab (c2):

$$
\begin{gathered}
\mathrm{M}_{\mathrm{c} 2}=\frac{\mathrm{W}_{\mathrm{c} 2} \times \mathrm{L}^{2}}{8}=\frac{17,431 \mathrm{~N} / \mathrm{m} \times(39.4 \mathrm{~m})^{2}}{8}=3,382,460 \mathrm{~N}-\mathrm{m} \\
\mathrm{f}_{\mathrm{st}}=\frac{-\mathrm{M}_{\mathrm{c} 2}}{\mathrm{Sx}_{4}}=\frac{-3,382,460 \mathrm{~N}-\mathrm{m}}{65,008 \mathrm{~cm}^{3}}=-5,203 \frac{\mathrm{N}}{\mathrm{cm}^{2}} \\
\mathrm{f}_{\mathrm{cb}}=\frac{\mathrm{M}_{\mathrm{c} 2}}{\mathrm{Sx}_{3}}=\frac{3,382,460 \mathrm{~N}-\mathrm{m}}{101,191 \mathrm{~cm}^{3}}=3,343 \frac{\mathrm{N}}{\mathrm{cm}^{2}} \\
\mathrm{f}_{\mathrm{cb}}=\frac{\mathrm{M}_{\mathrm{c} 2}}{\mathrm{~S}_{\mathrm{x} 9}}=\frac{3,382,460 \mathrm{~N}-\mathrm{m}}{701,189 \mathrm{~cm}^{3}}=482 \frac{\mathrm{N}}{\mathrm{cm}^{2}} \\
\mathrm{f}_{\mathrm{ct}}=\mathrm{N} / \mathrm{A}
\end{gathered}
$$

3. Concrete surrounding steel web (c3): 


$$
\begin{aligned}
& M_{c 3}=\frac{w_{c 3} \times L^{2}}{8}=\frac{3,885 \mathrm{~N} / \mathrm{m} \times(39.4 \mathrm{~m})^{2}}{8}=753,818 \mathrm{~N}-\mathrm{m} \\
& \mathrm{f}_{\mathrm{st}}=\frac{-\mathrm{M}_{\mathrm{c} 3}}{\mathrm{Sx}_{4}}=\frac{-753,818 \mathrm{~N}-\mathrm{m}}{65,008 \mathrm{~cm}^{3}}=-1,160 \frac{\mathrm{N}}{\mathrm{cm}^{2}} \\
& \mathrm{f}_{\mathrm{sb}}=\frac{\mathrm{M}_{\mathrm{c} 3}}{\mathrm{Sx}_{3}}=\frac{753,818 \mathrm{~N}-\mathrm{m}}{101,191 \mathrm{~cm}^{3}}=745 \frac{\mathrm{N}}{\mathrm{cm}^{2}} \\
& \mathrm{f}_{\mathrm{cb}}=\frac{\mathrm{M}_{\mathrm{c} 3}}{\mathrm{Sx}}=\frac{753,818 \mathrm{~N}-\mathrm{m}}{701,189 \mathrm{~cm}^{3}}=108 \frac{\mathrm{N}}{\mathrm{cm}^{2}} \\
& \mathrm{f}_{\mathrm{ct}}=\mathrm{N} / \mathrm{A}
\end{aligned}
$$

Stress check:

$$
\begin{aligned}
& f_{s t}=(-6,662-222-5,203-1,160) \frac{\mathrm{N}}{\mathrm{cm}^{2}}=-13,247 \frac{\mathrm{N}}{\mathrm{cm}^{2}} \\
& \mathrm{f}_{\mathrm{sb}}=(11,993+143+3,343+745) \frac{\mathrm{N}}{\mathrm{cm}^{2}}=16,223 \frac{\mathrm{N}}{\mathrm{cm}^{2}} \\
& f_{\text {st }}<f_{\text {s allow }}: 13,247<24,720: . \text { OK } \\
& f_{s b}<f_{s \text { allow }}: 16,223<24,720: . \text { OK } \\
& \mathrm{f}_{\mathrm{cb}}=(-1,497+21+482+108) \frac{\mathrm{N}}{\mathrm{cm}^{2}}=-886 \frac{\mathrm{N}}{\mathrm{cm}^{2}} \\
& f_{c b}<f_{c \text { allow }}: 886<2,060: . \text { OK }
\end{aligned}
$$

\section{Stage 4: Additional weight due to superimposed loads on concrete} slab

Once the top concrete (slab) is hardened, composite action is assumed between top and bottom concrete with the steel flanges. Similar to the previous loading cases, the areas and the moments of inertia of the concrete sections are divided by the modular ratio (n) in order to transform those properties into equivalent steel properties. 


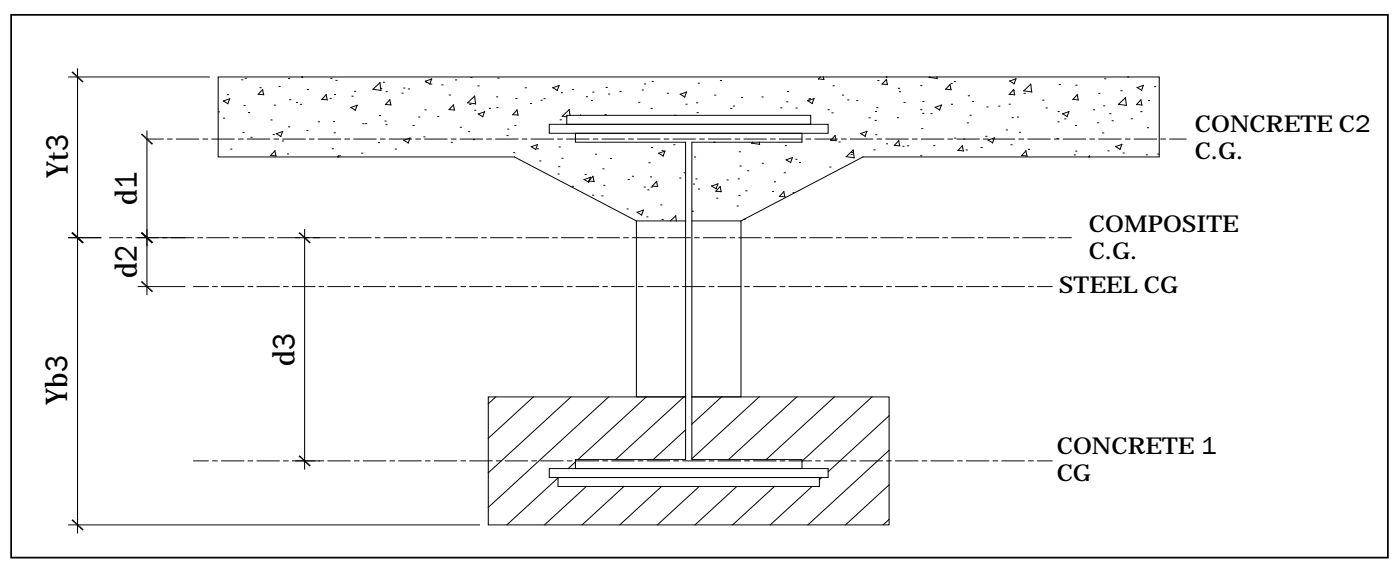

Figure 17. Full composite section and its centroid location.

For the example bridge:

1. Parapet:

$$
\begin{aligned}
& \mathrm{M}_{\mathrm{p}}=\frac{\mathrm{w}_{\mathrm{p}} \times \mathrm{L}^{2}}{8}=\frac{5,111.9 \mathrm{~N} / \mathrm{m} \times(39.4 \mathrm{~m})^{2}}{8}=991,933 \mathrm{~N}-\mathrm{m} \\
& \mathrm{f}_{\mathrm{st}}=\frac{-\mathrm{M}_{\mathrm{p}}}{\mathrm{Sx}_{8}}=\frac{-991,933 \mathrm{~N}-\mathrm{m}}{195,476 \mathrm{~cm}^{3}}=-507 \frac{\mathrm{N}}{\mathrm{cm}^{2}} \\
& \mathrm{f}_{\mathrm{sb}}=\frac{\mathrm{M}_{\mathrm{p}}}{\mathrm{Sx}_{7}}=\frac{991,933 \mathrm{~N}-\mathrm{m}}{135,654 \mathrm{~cm}^{3}}=731 \frac{\mathrm{N}}{\mathrm{cm}^{2}} \\
& \mathrm{f}_{\mathrm{cb}}=\mathrm{M}_{\mathrm{p}}=\frac{991,933 \mathrm{~N}-\mathrm{m}}{639,695 \mathrm{~cm}^{3}}=155 \frac{\mathrm{N}}{\mathrm{Cm}^{2}} \\
& \mathrm{f}_{\mathrm{ct}}=\frac{-\mathrm{M}_{\mathrm{p}}}{\mathrm{Sx}_{12}}=\frac{-991,933 \mathrm{~N}-\mathrm{m}}{864,920 \mathrm{~cm}^{3}}=-115 \frac{\mathrm{N}}{\mathrm{cm}^{2}}
\end{aligned}
$$

2. Wearing surface:

$$
\begin{aligned}
& \mathrm{M}_{\mathrm{ws}}=\frac{\mathrm{w}_{\mathrm{ws}} \times \mathrm{L}^{2}}{8}=\frac{4,412 \mathrm{~N} / \mathrm{m} \times(39.4 \mathrm{~m})^{2}}{8}=856,033 \mathrm{~N}-\mathrm{m} \\
& \mathrm{f}_{\mathrm{st}}=\frac{-\mathrm{M}_{\mathrm{ws}}}{\mathrm{S}_{\mathrm{x} 8}}=\frac{-856,033 \mathrm{~N}-\mathrm{m}}{195,476 \mathrm{~cm}^{3}}=-438 \frac{\mathrm{N}}{\mathrm{cm}^{2}}
\end{aligned}
$$




$$
\begin{aligned}
& \mathrm{f}_{\mathrm{sb}}=\frac{\mathrm{M}_{\mathrm{ws}}}{\mathrm{Sx}_{7}}=\frac{856,033 \mathrm{~N}-\mathrm{m}}{135,654 \mathrm{~cm}^{3}}=631 \frac{\mathrm{N}}{\mathrm{cm}^{2}} \\
& \mathrm{f}_{\mathrm{cb}}=\frac{\mathrm{M}_{\mathrm{ws}}}{\mathrm{Sx}_{11}}=\frac{856,033 \mathrm{~N}-\mathrm{m}}{639,695 \mathrm{~cm}^{3}}=134 \frac{\mathrm{N}}{\mathrm{cm}^{2}} \\
& \mathrm{f}_{\mathrm{ct}}=\frac{-\mathrm{M}_{\mathrm{ws}}}{\mathrm{Sx}_{12}}=\frac{-856,033 \mathrm{~N}-\mathrm{m}}{864,920 \mathrm{~cm}^{3}}=-99 \frac{\mathrm{N}}{\mathrm{cm}^{2}}
\end{aligned}
$$

3. Additional weight provided by posts, piping, etc.:

$$
\begin{aligned}
& \mathrm{M}_{\mathrm{ASL}}=\frac{\mathrm{w}_{\mathrm{ASL}} \times \mathrm{L}^{2}}{8}=\frac{882 \mathrm{~N} / \mathrm{m} \times(39.4 \mathrm{~m})^{2}}{8}=171,207 \mathrm{~N}-\mathrm{m} \\
& \mathrm{f}_{\mathrm{st}}=\frac{-\mathrm{M}_{\mathrm{ASL}}}{\mathrm{Sx}_{8}}=\frac{-171,207 \mathrm{~N}-\mathrm{m}}{195,476 \mathrm{~cm}^{3}}=-88 \frac{\mathrm{N}}{\mathrm{cm}^{2}} \\
& \mathrm{f}_{\mathrm{sb}}=\frac{\mathrm{M}_{\mathrm{ASL}}}{\mathrm{Sx}}=\frac{171,207 \mathrm{~N}-\mathrm{m}}{135,654 \mathrm{~cm}^{3}}=126 \frac{\mathrm{N}}{\mathrm{cm}^{2}} \\
& \mathrm{f}_{\mathrm{cb}}=\frac{\mathrm{M}_{\mathrm{ASL}}}{\mathrm{Sx}_{11}}=\frac{171,207 \mathrm{~N}-\mathrm{m}}{639,695 \mathrm{~cm}^{3}}=27 \frac{\mathrm{N}}{\mathrm{cm}^{2}} \\
& \mathrm{f}_{\mathrm{ct}}=\frac{-\mathrm{M}_{\mathrm{ASL}}}{\mathrm{Sx}_{12}}=\frac{-171,207 \mathrm{~N}-\mathrm{m}}{864,920 \mathrm{~cm}^{3}}=-20 \frac{\mathrm{N}}{\mathrm{cm}^{2}}
\end{aligned}
$$

Stress check:

$$
\begin{aligned}
& \mathrm{f}_{\mathrm{st}}=(-13,247-507-438-88) \frac{\mathrm{N}}{\mathrm{cm}^{2}}=-14,280 \frac{\mathrm{N}}{\mathrm{cm}^{2}} \\
& \mathrm{f}_{\mathrm{sb}}=(16,223+731+631+126) \frac{\mathrm{N}}{\mathrm{cm}^{2}}=17,712 \frac{\mathrm{N}}{\mathrm{cm}^{2}} \\
& f_{\text {st }}<f_{\text {s allow }}: 14,280<24,720: . \text { OK } \\
& f_{\mathrm{sb}}<f_{\mathrm{s} \text { allow }}: 17,712<24,720: . \text { OK } \\
& \mathrm{f}_{\mathrm{cb}}=(-886+155+134+27) \frac{\mathrm{N}}{\mathrm{cm}^{2}}=-571 \frac{\mathrm{N}}{\mathrm{cm}^{2}} \\
& \mathrm{f}_{\mathrm{ct}}=(-115-99-20) \frac{\mathrm{N}}{\mathrm{cm}^{2}}=-233 \frac{\mathrm{N}}{\mathrm{cm}^{2}} \\
& f_{c b}<f_{c \text { allow }}: 571<2,060: . \text { OK }
\end{aligned}
$$




$$
f_{\text {ct }}<f_{\text {c allow }}: 233<2,060: . \text { OK }
$$

\section{Stage 5: Live load effect on composite section}

The live load moment, shown here, was determined in the previous section, and its stress effect in the composite beam will be computed next.

$$
\begin{gathered}
\mathrm{M}_{(\mathrm{HS} 20+\mathrm{IM})}=2,705,000 \mathrm{~N}-\mathrm{m} \\
\mathrm{f}_{\mathrm{st}}=\frac{-\mathrm{M}_{(\mathrm{HS} 20+\mathrm{IM})}}{\mathrm{Sx}_{8}}=\frac{-2,705,000 \mathrm{~N}-\mathrm{m}}{195,476 \mathrm{~cm}^{3}}=-1,384 \frac{\mathrm{N}}{\mathrm{cm}^{2}} \\
\mathrm{f}_{\mathrm{sb}}=\frac{\mathrm{M}_{(\mathrm{HS} 20+\mathrm{IM})}}{\mathrm{Sx}_{7}}=\frac{2,705,000 \mathrm{~N}-\mathrm{m}}{135,654 \mathrm{~cm}^{3}}=1,994 \frac{\mathrm{N}}{\mathrm{cm}^{2}} \\
\mathrm{f}_{\mathrm{cb}}=\frac{\mathrm{M}_{(\mathrm{HS} 20+\mathrm{IM})}}{\mathrm{Sx}_{11}}=\frac{2,705,000 \mathrm{~N}-\mathrm{m}}{639,695 \mathrm{~cm}^{3}}=423 \frac{\mathrm{N}}{\mathrm{cm}^{2}} \\
\mathrm{f}_{\mathrm{ct}}=\frac{-\mathrm{M}_{(\mathrm{HS} 20+\mathrm{IM})}}{\mathrm{Sx}_{12}}=\frac{-2,705,000 \mathrm{~N}-\mathrm{m}}{864,920 \mathrm{~cm}^{3}}=-313 \frac{\mathrm{N}}{\mathrm{cm}^{2}}
\end{gathered}
$$

Stress check:

$$
\begin{aligned}
& \mathrm{f}_{\mathrm{st}}=(-14,280-1,384) \frac{\mathrm{N}}{\mathrm{cm}^{2}}=-15,664 \frac{\mathrm{N}}{\mathrm{cm}^{2}} \\
& \mathrm{f}_{\mathrm{sb}}=(17,712+1,994) \frac{\mathrm{N}}{\mathrm{cm}^{2}}=19,706 \frac{\mathrm{N}}{\mathrm{cm}^{2}} \\
& f_{\text {st }}<f_{\text {s allow }}: 15,664<24,720: . \text { OK } \\
& f_{\mathrm{sb}}<f_{\mathrm{s} \text { allow }}: 19,706<24,720: . \mathrm{OK} \\
& \mathrm{f}_{\mathrm{cb}}=(-571+423) \frac{\mathrm{N}}{\mathrm{cm}^{2}}=-148 \frac{\mathrm{N}}{\mathrm{cm}^{2}} \\
& \mathrm{f}_{\mathrm{ct}}=(-233-313) \frac{\mathrm{N}}{\mathrm{cm}^{2}}=-546 \frac{\mathrm{N}}{\mathrm{cm}^{2}} \\
& f_{c b}<f_{c \text { allow }}: 148<2,060: . \text { OK } \\
& f_{c t}<f_{c \text { allow }}: 546<2,060: . \text { OK }
\end{aligned}
$$


The results of all stress calculations previously shown are summarized in Table 7. The allowable stresses of both steel and concrete were not exceeded at any of the five loading stages.

Table 7. Stress values for different stages of loading.

\begin{tabular}{|c|c|c|c|c|c|c|}
\hline \multirow{2}{*}{$\begin{array}{l}\text { Loading } \\
\text { Stage }\end{array}$} & Load & Moment & $f_{s t}$ & $f_{s b}$ & $f_{c b}$ & $f_{c t}$ \\
\hline & $\mathrm{N} / \mathrm{m}$ & $\mathrm{N} / \mathrm{m}$ & $\mathrm{N} / \mathrm{cm}^{2}$ & $\mathrm{~N} / \mathrm{cm}^{2}$ & $\mathrm{~N} / \mathrm{cm}^{2}$ & $\mathrm{~N} / \mathrm{cm}^{2}$ \\
\hline \multicolumn{2}{|l|}{ Preflexion Load: } & $14,372,000$ & $-22,806$ & 22,364 & 0 & 0 \\
\hline \multirow{2}{*}{\multicolumn{3}{|c|}{ Allowable Stress Stage 1: Pre-flex load }} & \multicolumn{2}{|l|}{24,720} & \multicolumn{2}{|l|}{2,060} \\
\hline & & & OK & $\mathrm{OK}$ & OK & OK \\
\hline \multicolumn{2}{|l|}{ Release: } & $-14,372,000$ & 22,108 & $-14,203$ & $-2,050$ & 0 \\
\hline Pre-flex Beam: & 19,983 & $3,877,614$ & $-5,965$ & 3,832 & 553 & 0 \\
\hline \multicolumn{3}{|r|}{ Total: } & $-6,662$ & 11,993 & $-1,497$ & 0 \\
\hline \multirow{2}{*}{\multicolumn{3}{|c|}{$\begin{array}{l}\text { Allowable Stress Stage 2: Release and beam self- } \\
\text { weight }\end{array}$}} & \multicolumn{2}{|l|}{24,720} & \multicolumn{2}{|l|}{2,060} \\
\hline & & & OK & OK & OK & $\mathrm{OK}$ \\
\hline Diaphragm: & 744 & 144,433 & -222 & 143 & 21 & 0 \\
\hline Slab: & 17,431 & $3,382,460$ & $-5,203$ & 3,343 & 482 & 0 \\
\hline Concrete Web: & 3,885 & 753,818 & $-1,160$ & 745 & 108 & 0 \\
\hline \multicolumn{3}{|r|}{ Total: } & $-13,247$ & 16,223 & -886 & 0 \\
\hline \multirow{2}{*}{\multicolumn{3}{|c|}{$\begin{array}{l}\text { Allowable Stress Stage 3: Concrete slab, diaphragm, } \\
\text { and concrete web }\end{array}$}} & \multicolumn{2}{|l|}{24,720} & \multicolumn{2}{|l|}{2,060} \\
\hline & & & OK & $\mathrm{OK}$ & OK & OK \\
\hline Parapet: & 5,112 & 991,933 & -507 & 731 & 155 & -115 \\
\hline Wearing Surface: & 4,412 & 856,033 & -438 & 631 & 134 & -99 \\
\hline Additional Weight: & 882 & 171,207 & -88 & 126 & 27 & -20 \\
\hline \multicolumn{3}{|l|}{ Total: } & $-14,280$ & 17,712 & -571 & -233 \\
\hline \multirow{2}{*}{\multicolumn{3}{|c|}{$\begin{array}{l}\text { Allowable Stress Stage 4: Superimposed loads on } \\
\text { concrete slab }\end{array}$}} & \multicolumn{2}{|l|}{24,720} & \multicolumn{2}{|l|}{2,060} \\
\hline & & & OK & $\mathrm{OK}$ & $\mathrm{OK}$ & $\mathrm{OK}$ \\
\hline Live Load: & & $2,705,000$ & $-1,384$ & 1,994 & 423 & -313 \\
\hline \multicolumn{3}{|r|}{ Total: } & $-15,664$ & 19,706 & -148 & -546 \\
\hline \multirow{2}{*}{\multicolumn{3}{|c|}{ Allowable Stress Stage 5: Live load }} & \multicolumn{2}{|l|}{24,720} & \multicolumn{2}{|l|}{2,060} \\
\hline & & & OK & OK & OK & OK \\
\hline
\end{tabular}




\section{Creep and Shrinkage}

The use of high-strength concrete in pre-stressed members has become accepted by many state highway agencies. In pre-stressed and posttensioned concrete systems, the initial stresses are reduced by long-term effects like creep and shrinkage. The time-dependent creep and shrinkage effects must be taken into account with sufficient accuracy. However, realistic estimates of pre-stress losses in these structures cannot be predicted with current AASHTO and American Concrete Institute (ACI) provisions, which work fairly well with normal strength concrete. Tadros and Al-Omaishi (2003) developed a detailed method and an approximate method for estimating pre-stress losses in pre-tensioned high-strength concrete bridges. In their work, Tadros and Al-Omaishi concluded that local material properties significantly impacted the prediction of modulus of elasticity, shrinkage, and creep.

The complexity of a section comprised of steel and two concrete flanges (poured at different times, with similar or dissimilar properties) may require laborious calculations. For the example bridge, these effects are calculated at different stages of loading and age of concrete. The procedures for the calculation of the stresses and deflection due to creep and shrinkage included in this section are adopted from Giacomo and Mannini (2006.)

\section{General considerations}

Using concrete age-adjusted modular ratios, Giacomo and Maninni's formulation (developed for pre-flex beams) allow the transformation of the composite section into an equivalent homogeneous steel section, and straight forward stress calculations during the whole life of the structure can be executed.

Axial forces and bending moments developed in the composite pre-flex beam are obtained. Creep and shrinkage effects on pre-flex beams are calculated under the action of initial pre-flexion and subsequent stages of loading during construction and service. These values are uncoupled for the steel beam and the concrete section surrounding the bottom flange. 
The basic assumptions are

1. Plane sections remain plane. Thus, strain distribution on any section at any time is linear.

2. There is no slip at the steel-concrete interfaces (rigid connections, full transfer of loads).

3. Linear elastic behavior is assumed for structural steel; linear visco-elastic behavior is assumed for concrete (uncracked).

4. Superposition principle holds.

The procedure consists of solving a system of four equations (Equations 4-7) that relate the forces, moments, strain, and curvature of the steel and concrete.

$$
\begin{gathered}
\mathrm{N}_{\mathrm{s}}(\mathrm{t})+\mathrm{N}_{\mathrm{c}}(\mathrm{t})=0 \\
\mathrm{M}_{\mathrm{s}}(\mathrm{t})+\mathrm{M}_{\mathrm{c}}(\mathrm{t})+\mathrm{N}_{\mathrm{c}}(\mathrm{t}) \times \mathrm{d}=0 \\
\varepsilon_{\mathrm{s}}(\mathrm{t})=\varepsilon_{\mathrm{c}}(\mathrm{t}) \\
\mathrm{C}_{\mathrm{s}}(\mathrm{t})=\mathrm{C}_{\mathrm{c}}(\mathrm{t})
\end{gathered}
$$

where:

$\mathrm{N}_{\mathrm{c}}(\mathrm{t}), \mathrm{N}_{\mathrm{s}}(\mathrm{t})=$ axial force in concrete and steel beam, respectively, at the time of consideration

$\mathrm{d}=$ distance between centroids of structural steel and concrete, at the time of consideration

$\mathrm{M}_{\mathrm{c}}(\mathrm{t}), \mathrm{M}_{\mathrm{s}}(\mathrm{t})$ = bending moment in concrete and steel beam, respectively, at the time of consideration

$\varepsilon_{\mathrm{C}}(\mathrm{t}), \varepsilon_{\mathrm{S}}(\mathrm{t})=$ concrete and steel strain in fiber corresponding to concrete centroid, at the time of consideration

$\mathrm{C}_{\mathrm{c}}(\mathrm{t}), \mathrm{C}_{\mathrm{s}}(\mathrm{t})=$ curvature of concrete section and of steel beam, respectively, at the time of consideration

Figure 18 shows the sign convention for the terms previously defined. 


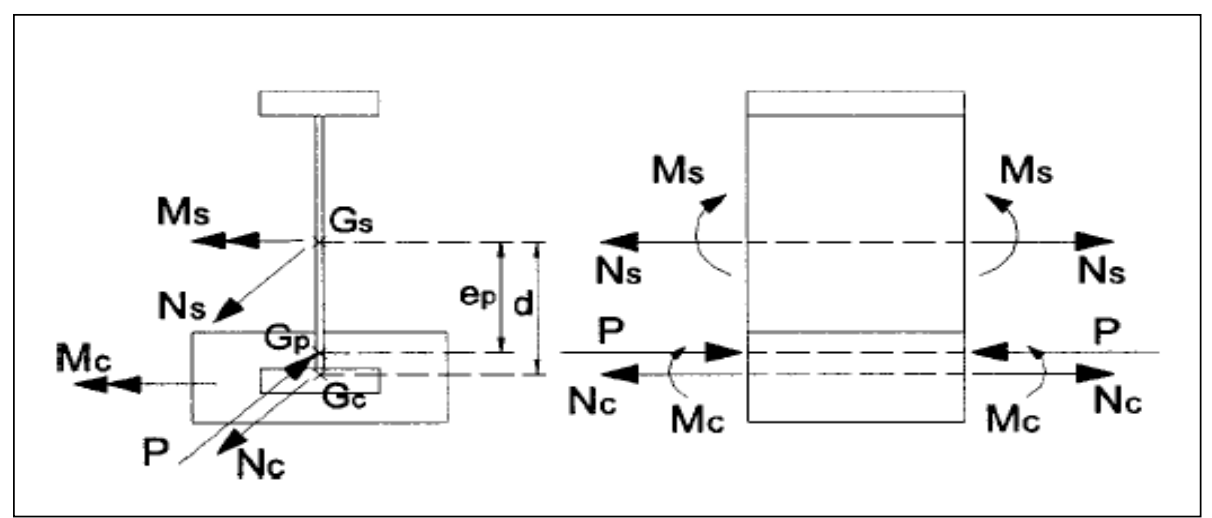

Figure 18. Sign convention of internal and external forces, from Giacomo and Mannini.

Before solving the system of equations, the following parameters must be determined:

1. Modular ratio at 28 days, $\mathrm{n}_{28}$,

2. Moment and axial force modular ratio coefficient $\alpha(t)$

3. Ultimate and time-dependent creep coefficients

The $\alpha(t)$ value is assumed as 0.20 for young high-strength concrete $\left(t_{0}=\right.$ 3 -day) and 0.02 for mature high-strength concrete ( $\mathrm{t}_{0}=28$-day). For normal-strength concrete and the same initial time of loading, the modular ratio coefficients are commonly incremented by a factor of 2.5. For normal strength concrete with initial loading at $t=28$-day, a value of 0.1 is obtained by interpolation from values given by Giacomo and Mannini (2006). However, ACI 209 provides values 3.5 times higher, but the effects in the calculations of deflections are negligible (ACI 1992). For simplicity, a value of 0.20 has been applied for both normal- and high-strength concrete.

Giacomo and Maninni solved the system of equations by introducing moment and axial force modular ratios that vary with time. These modular ratios are used to distribute the moment and axial forces between the steel and concrete. Giacomo and Mannini provide equations for creep and shrinkage that are illustrated here.

\section{Stresses due to creep and shrinkage}

During the design process, the effects of creep and shrinkage are present in the pre-flex beam by means of a reduction of the initial pre-stresses that result during the recovery process after the initial deflection. The stresses 
due to creep and shrinkage are found with the basic stress formula in Equation 8.

$$
f_{i}(t)= \pm \frac{N_{i}(t)}{A_{i}} \pm \frac{M_{i}(t)}{S_{i}}
$$

where: the subscript " $\mathrm{i}$ " refers to concrete or steel. The stresses in the steel $\mathrm{f}_{\mathrm{s}}(\mathrm{t})$ and concrete $\mathrm{f}_{\mathrm{c}}(\mathrm{t})$ are then added to the corresponding stresses found for each loading case, taking into account the time in which the load is applied and its duration.

\section{Methodology for calculation of creep and shrinkage effects}

Although the formulations were established for a pre-flex beam encased with concrete only at its bottom flange, in this study, the same concepts are applied, employing superposition for the different stages of loading. These stages are:

Stage 1: Noncomposite steel beam subjected to pre-flexion: Creep and shrinkage effects are not considered for this stage.

Stage 2: Release of pre-flex loading after initial time of loading (i.e., $t_{0}=3$-day) on concrete located at the bottom flange of the beam. This is considered Phase 1 of creep and shrinkage effects. In this phase, the loads associated with the release of pre-flex, the selfweight of the steel beam, and the weight of concrete 1 are included. In practice, the shrinkage effects are commonly neglected at this stage due to rigid connection to the steel flange.

Stage 3: In this stage, the load of the slab is included to the pre-flex beam, but the concrete at the top flange is not providing composite action to the beam, as the concrete at the bottom flange is. This is Phase 2 of creep and shrinkage, and the loads included are the release of pre-flex, the self-weight of the steel beam, and the weight of concretes $\mathrm{c} 1, \mathrm{c} 2$, and c3.

Stage 4: Pre-flex beam with top and bottom concrete provides composite action at top and bottom flanges. This is Phase 3 of creep and shrinkage. For this phase, the beam was analyzed upside down with the same equations provided by Giacomo and Maninni, with a 
transformed steel beam section (steel and c1). The loads included are the superimposed dead loads.

\section{Creep and shrinkage: Phase 1}

\section{Initial time of loading: $t_{0}=3-d a y$}

With the assumption that the pre-flex beam is released after three days of the initial curing period, the allowable concrete compressive stress cannot be exceeded at this time. However, considerable changes in creep deflecttions are not found for small variations of the initial time of loading (i.e., from 3 to 7 days) if the total period of loading does not exceed 30 days.

\section{Final time of loading: $t=31$-day}

The duration of this stage ( $3+28=31$-day) represents the period of time to transport and mount the beam and to set up all forms (molds), rebar, and other internal attachments (pipes, conduits, etc.) to the concrete slab, prior to concrete pouring. This period of time can be adjusted if it is predetermined by construction contracts. The duration will also depend on the dimensions and complexity of the superstructure.

\section{Loading}

The loads acting in this phase are $\mathrm{F}_{\text {Release }}+\mathrm{w}_{\mathrm{g}}+\mathrm{w}_{\mathrm{c} 1}$

where:

$$
\begin{aligned}
\mathrm{F}_{\text {Release }}= & \text { release load } \\
\mathrm{w}_{\mathrm{g}}= & \text { self-weight of steel beam } \\
\mathrm{W}_{\mathrm{c} 1}= & \text { weight of concrete block encasing the bottom flange of the } \\
& \text { steel beam. }
\end{aligned}
$$

The bending moment produced by the release of pre-flex and the selfweight of the composite beam is

$$
\mathrm{M}_{\text {Phase } 1}=(-14,372,000+3,877,614) \mathrm{N}-\mathrm{m}=-10,494,386 \mathrm{~N}-\mathrm{m}
$$




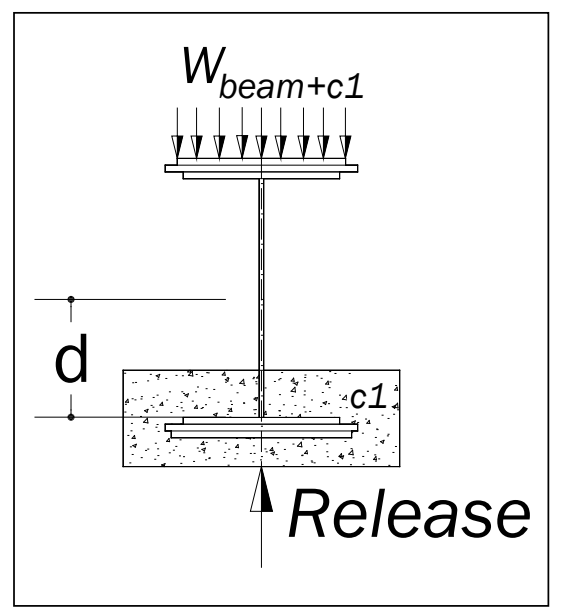

Figure 19. Loads and element sections considered for Phase 1 of creep and shrinkage.

\section{Properties of elements}

For this phase, the individual inertia for the steel beam $\left(\mathrm{I}_{\mathrm{s}}\right)$ and the concrete block at the bottom flange ( $\left.\mathrm{I}_{\text {all11}}\right)$ with respect to its centroidal axes are considered. The concrete stress for the initial loading condition ( $t_{0}=3$ - day) is assumed as $\mathrm{f}_{\mathrm{ci}}^{\prime}=0.4 \mathrm{f}_{\mathrm{c}}^{\prime}$.

\section{Creep and shrinkage effects}

For $t_{0}=3$-day:

$$
\mathrm{f}_{\mathrm{ci}}=0.4 \times \mathrm{f}_{\mathrm{c}}=0.4 \times 5,150 \mathrm{~N} / \mathrm{cm}^{2}=2,060 \mathrm{~N} / \mathrm{cm}^{2}
$$

The modulus of elasticity of concrete can be calculated using the ACI code (ACI 1992) presented in Equation 9.

$$
\mathrm{E}_{\mathrm{c}\left(\mathrm{t}_{0}\right)}=0.043 \times \mathrm{w}_{\mathrm{c}}^{1.5} \sqrt{\mathrm{f}_{\mathrm{ci}}}
$$

where:

$$
\begin{aligned}
\mathrm{w}_{\mathrm{c}}^{\prime} & =\text { concrete density }\left(\mathrm{kg} / \mathrm{m}^{3}\right) \\
\mathrm{f}_{\mathrm{ci}}^{\prime} & =\text { early compressive strength of concrete }(\mathrm{MPa})
\end{aligned}
$$




$$
\begin{aligned}
& \mathrm{E}_{\mathrm{c}\left(\mathrm{t}_{\mathrm{o}}\right)}=0.043 \times \mathrm{w}_{\mathrm{c}}^{\prime 1.5} \sqrt{\mathrm{f}_{\mathrm{ci}}^{\prime}}=0.043 \times\left(2,400 \mathrm{~kg} / \mathrm{m}^{3}\right)^{1.5} \sqrt{20.60 \mathrm{MPa}} \\
& \mathrm{E}_{\mathrm{c}\left(\mathrm{t}_{\mathrm{o}}\right)}=22,947 \mathrm{MPa}=2,294,663 \mathrm{~N} / \mathrm{cm}^{2}
\end{aligned}
$$

The creep coefficient at any time, $C_{t}$, can be related to the ultimate creep coefficient, $C_{u}$ (Equation 10).

$$
\mathrm{C}_{\mathrm{t}}=\mathrm{C}_{\mathrm{u}} \times \frac{\mathrm{t}^{0.6}}{10+\mathrm{t}^{0.6}} \times \lambda_{1} \times \lambda_{2}
$$

where:

$C_{u}=2.35$, a typical creep coefficient for concrete with 28-day compressive strength of $51.5 \mathrm{MPa}$

$\lambda_{1}=1.25\left(t_{o^{-0.118}}\right)$ for moist cured concrete

$\lambda_{1}=1.13\left(t_{o}{ }^{-0.094}\right)$ for steam cured concrete

$\lambda_{2}=$ humidity index correction factor

If the initial time of loading is $t_{0}<7$-day, use $\lambda_{1}=1.25$ or 1.13 , respectively. For this case: $t_{o}=3$-day, thus $\lambda_{1}=1.25$.

The basic formula considers a basic humidity index of $40 \%$. For humidity index, $\mathrm{H}(65 \%)$, greater than $40 \%$, a correction factor $\lambda_{2}$ must be applied as follows:

$$
\begin{aligned}
& \lambda_{2}=1.27-0.0067 \mathrm{H}=1.27-0.0067(65)=0.835 \\
& \mathrm{C}_{\mathrm{t}}=\mathrm{C}_{\mathrm{u}} \times \frac{\mathrm{t}^{0.6}}{10+\mathrm{t}^{0.6}} \times \lambda_{1} \times \lambda_{2}=2.35 \times \frac{31^{0.6}}{10+31^{0.6}} \times 1.25 \times 0.835=1.078
\end{aligned}
$$

The creep core $\Gamma\left(t_{o}, t\right)$ is assumed in Equation 11 as:

$$
\Gamma\left(\mathrm{t}_{0}, \mathrm{t}\right)=\frac{\mathrm{E}_{\mathrm{c}\left(\mathrm{t}_{0}\right)}}{\mathrm{E}_{\mathrm{c} 28}}+\mathrm{C}_{\mathrm{t}}
$$

where:

$$
\begin{aligned}
& E_{\mathrm{c} 28}=\text { modulus of elasticity for concrete after } 28 \text { days } \\
& =36.289 \mathrm{GPa}=3,628,900 \mathrm{~N} / \mathrm{cm}^{2} \\
& E_{c(t o)}=\text { modulus of elasticity for concrete at initial time of loading } \\
& =2,294,663 \mathrm{~N} / \mathrm{cm}^{2}
\end{aligned}
$$




$$
\Gamma\left(\mathrm{t}_{\mathrm{o}}, \mathrm{t}\right)=\frac{\mathrm{E}_{\mathrm{c}\left(\mathrm{t}_{\mathrm{o}}\right)}}{\mathrm{E}_{\mathrm{c} 28}}+\mathrm{C}_{\mathrm{t}}=\frac{2,294,663 \mathrm{~N} / \mathrm{cm}^{2}}{3,628,900 \mathrm{~N} / \mathrm{cm}^{2}}+1.078=1.710
$$

The adjusted modular ratios are defined as:

$$
\begin{aligned}
& \mathrm{n}_{\left(\mathrm{t}_{\mathrm{o}}\right)}=\frac{\mathrm{E}_{\mathrm{s}}}{\mathrm{E}_{\mathrm{c}}\left(\mathrm{t}_{\mathrm{o}}\right)}=\frac{20,110,500 \mathrm{~N} / \mathrm{cm}^{2}}{2,294,663 \mathrm{~N} / \mathrm{cm}^{2}}=8.764 \\
& \mathrm{n}_{28}=\frac{\mathrm{E}_{\mathrm{s}}}{\mathrm{E}_{\mathrm{c} 28}}=\frac{20,110,500 \mathrm{~N} / \mathrm{cm}^{2}}{3,628,900 \mathrm{~N} / \mathrm{cm}^{2}}=5.542
\end{aligned}
$$

For the axial loads, the modular ratio, considering creep effects, is based on the following in Equation 12:

$$
\mathrm{n}_{\mathrm{N}}(\mathrm{t})=\frac{\Gamma\left(\mathrm{t}_{0}, \mathrm{t}\right) \times\left(\frac{\mathrm{A}_{\mathrm{c}}}{\mathrm{A}_{\mathrm{s}}}+\frac{\mathrm{A}_{\mathrm{c}} \mathrm{d}^{2}}{\mathrm{I}_{\mathrm{s}}}\right)+\left[(1-\alpha) \times \Gamma\left(\mathrm{t}_{0}, \mathrm{t}\right)+\alpha\right] \times \mathrm{n}_{\mathrm{i}}}{\mathrm{n}_{\mathrm{i}}+\frac{\mathrm{A}_{\mathrm{c}}}{\mathrm{A}_{\mathrm{s}}}+\frac{\mathrm{A}_{\mathrm{c}} \mathrm{d}^{2}}{\mathrm{I}_{\mathrm{s}}}-\mathrm{n}_{28} \times \alpha \times\left[\Gamma\left(\mathrm{t}_{0}, \mathrm{t}\right)-1\right]} \times \mathrm{n}_{28}
$$

where:

$$
\begin{aligned}
\mathrm{n}_{\mathrm{N}}(\mathrm{t})= & \text { axial force modular ratio } \\
\mathrm{A}_{\mathrm{c}}= & 3,949 \mathrm{~cm}^{2} \\
\mathrm{~A}_{\mathrm{s}}= & 1,397 \mathrm{~cm}^{2} \\
\mathrm{~d}= & 48.91 \mathrm{~cm}=\text { distance between centers of gravity of steel and } \\
& \text { concrete } \\
\alpha= & 0.2, \text { determines the stress relaxation path due to creep } \\
\mathrm{I}_{\mathrm{S}}= & 3,690,893 \mathrm{~cm} 4 \\
\mathrm{n}_{\mathrm{i}}= & \mathrm{n}_{(\mathrm{to})}=8.764 \\
\mathrm{n}_{28}= & 5.542 \\
& 1.710 \times\left(\frac{3,949}{1,397}+\frac{3,949 \times(48.91)^{2}}{3,690,893}\right)+[(1-0.2) \times 1.710+0.2] \times 8.764 \\
\mathrm{n}_{\mathrm{N}}(\mathrm{t})= & 8.764+\frac{3,949}{1,397}+\frac{3,949 \times(48.91)^{2}}{3,690,893}-5.542 \times 0.2 \times(1.710-1) \\
\mathrm{n}_{\mathrm{N}}(\mathrm{t})= & 9.520
\end{aligned}
$$


The axial force in the concrete, $N_{c}(t)$, is then found with Equation 13:

$$
\begin{gathered}
\mathrm{N}_{\mathrm{c}}(\mathrm{t})=\frac{\mathrm{M}\left(\frac{\mathrm{A}_{\mathrm{c}} \mathrm{d}}{\mathrm{I}_{\mathrm{s}}}\right)}{\mathrm{n}_{\mathrm{N}}(\mathrm{t})+\frac{\mathrm{A}_{\mathrm{c}}}{\mathrm{A}_{\mathrm{s}}}+\frac{\mathrm{A}_{\mathrm{c}} \mathrm{d}^{2}}{\mathrm{I}_{\mathrm{s}}}} \\
\mathrm{N}_{\mathrm{c}}(t)=\frac{-10,4894,386 \mathrm{~N}-\mathrm{m} \times\left(\frac{3,949 \mathrm{~cm}^{2} \times 48.91 \mathrm{~cm}}{3,690,893 \mathrm{~cm}^{4}}\right)}{9.520+\frac{3,949 \mathrm{~cm}^{2}}{1,397 \mathrm{~cm}^{2}}+\frac{3,949 \mathrm{~cm}^{2} \times(48.91 \mathrm{~cm})^{2}}{3,690,893 \mathrm{~cm}^{4}}} \\
\mathrm{~N}_{\mathrm{c}}(t)=-3,683,770 \mathrm{~N}
\end{gathered}
$$

By the equilibrium of axial forces, the axial force in the steel is calculated using Equation 4, as illustrated as follows:

$$
N_{s}(t)=-N_{c}(t)=-(-3,683,770 N)=3,683,770 N
$$

In order to find the moment modular ratio, two constants must be determined first. These are the values of $\beta(t)$ and $\gamma$, which are found with Equations 14 and 15, respectively.

$$
\begin{aligned}
& \beta(t)=\frac{n_{i}+\frac{A_{c}}{A_{s}}}{n_{N}(t)+\frac{A_{c}}{A_{s}}} \times \frac{n_{N}(t)+\frac{A_{c}}{A_{s}}+\frac{A_{c} d^{2}}{I_{s}}}{\left.I_{i}+\frac{A_{c}}{A_{s}}\right)+n_{i}\left(n_{i}+\frac{A_{c}}{A_{s}}+\frac{A_{c} d^{2}}{I_{s}}\right)} \\
& =\frac{8.764+\frac{3,949}{1,397}}{9.520+\frac{3,949}{1,397}} \times \frac{9.520+\frac{3,949}{1,397}+\frac{3,949 \times(48.91)^{2}}{3,690,893}}{\frac{594,493}{3,690,893}\left(8.764+\frac{3,949}{1,397}\right)+8.764\left(8.764+\frac{3,949}{1,397}+\frac{3,949 \times(48.91)^{2}}{3,690,893}\right)} \\
& \beta(t)=0.111 \\
& \gamma=\frac{n_{i}\left(n_{i}+\frac{A_{c}}{A_{s}}+\frac{A_{c} d^{2}}{I_{s}}\right)}{\frac{I_{c}}{I_{s}}\left(n_{i}+\frac{A_{c}}{A_{s}}\right)+n_{i}\left(n_{i}+\frac{A_{c}}{A_{s}}+\frac{A_{c} d^{2}}{I_{s}}\right)}
\end{aligned}
$$




$$
\begin{aligned}
& \gamma=\frac{8.764\left(8.764+\frac{3,949}{1,397}+\frac{3,949 \times(48.91)^{2}}{3,690,893}\right)}{\frac{594,493}{3,690,893}\left(8.764+\frac{3,949}{1,397}\right)+8.764\left(8.764+\frac{3,949}{1,397}+\frac{3,949 \times(48.91)^{2}}{3,690,893}\right)} \\
& \gamma=0.985
\end{aligned}
$$

The bending moment modular ratio, $\mathrm{n}_{\mathrm{M}}(\mathrm{t})$, can be found with Equation 16:

$$
\mathrm{n}_{\mathrm{M}}(\mathrm{t})=\frac{\Gamma\left(\mathrm{t}_{0}, \mathrm{t}\right)-\mathrm{a}_{\mathrm{M}}\left[\Gamma\left(\mathrm{t}_{0}, \mathrm{t}\right)-1\right] \times \gamma}{1-\mathrm{n}_{28} \times \mathrm{a}_{\mathrm{M}} \times\left[\Gamma\left(\mathrm{t}_{0}, \mathrm{t}\right)-1\right] \times \beta(\mathrm{t})} \times \mathrm{n}_{28}
$$

where:

$$
\begin{aligned}
\alpha_{\mathrm{M}}= & 0.2, \text { determines the stress relaxation path due to creep and is } \\
& \text { similar to } \alpha . \\
\mathrm{I}_{\mathrm{C}}= & 594,493 \mathrm{~cm} 4 \\
& \mathrm{n}_{\mathrm{M}}(\mathrm{t})=\frac{1.710-0.2(1.710-1) \times 0.985}{1-5.542 \times 0.2 \times(1.710-1) \times 0.111} \times 5.542=9.537
\end{aligned}
$$

Having found the constants and the moment modular ratio, the moment in the concrete is found with Equation 17:

$$
\begin{aligned}
& M_{c}(t)=\frac{n_{N}(t)+\frac{A_{c}}{A_{s}}}{\frac{I_{c}}{I_{s}} \times\left[n_{N}(t)+\frac{A_{c}}{A_{s}}\right]+n_{M}(t) \times\left[n_{N}(t)+\frac{A_{c}}{A_{s}}+\frac{A_{c} d^{2}}{I_{s}}\right]} \times M \frac{I_{c}}{I_{s}} \\
& =\frac{9.520+\frac{3,949}{1,397}}{\frac{594,493}{3,690,893}\left[9.520+\frac{3,949}{1,397}\right]+9.537 \times\left[9.520+\frac{3,949}{1,397}+\frac{3,949 \times(48.91)^{2}}{3,690,893}\right]} \times \mathrm{M} \frac{594,493}{3,690,893} \\
& M_{c}(t)=0.0138 \times M=0.0138 \times(-10,494,386 N-m)=-144,782 N-m
\end{aligned}
$$

The moment in the steel, $\mathrm{M}_{\mathrm{s}}(\mathrm{t})$, is then found using Equation 5:

$$
\begin{aligned}
& M_{s}(t)=M-M_{c}(t)-N_{c}(t) \times d \\
& =(-10,494,386 N-m)-(-144,782 N-m)-(-3,683,770 N) \times 48.91 \mathrm{~cm} \\
& M_{s}(t)=-8,547,872 N-m
\end{aligned}
$$


The axial forces produced by shrinkage are found in a similar way as the axial forces produced by creep. The axial force modular ratio is determined using Equation 18:

$$
\begin{gathered}
\mathrm{n}_{\mathrm{N}}(\mathrm{t})=\mathrm{n}_{28} \times\left[(1-\alpha) \times \Gamma\left(\mathrm{t}_{\mathrm{o}}, \mathrm{t}\right)+\alpha\right] \\
\mathrm{n}_{\mathrm{N}}(\mathrm{t})=5.542 \times[(1-0.2) \times 1.710+0.2]=8.691
\end{gathered}
$$

For shrinkage, it has been demonstrated that the moment modular ratio, $\mathrm{n}_{\mathrm{M}}(\mathrm{t})$, is equal to the axial force modular ratio, $\mathrm{n}_{\mathrm{N}}(\mathrm{t})$, thus:

$$
\mathrm{n}_{\mathrm{N}}(\mathrm{t})=\mathrm{n}_{\mathrm{M}}(\mathrm{t})=8.691
$$

The moments and axial forces for shrinkage are found in the same way as for creep.

$\mathrm{N}_{\mathrm{c}}(\mathrm{t})=\frac{\mathrm{M}\left(\frac{\mathrm{A}_{\mathrm{c}} \mathrm{d}}{\mathrm{I}_{\mathrm{s}}}\right)}{\mathrm{n}_{\mathrm{N}}(\mathrm{t})+\frac{\mathrm{A}_{\mathrm{c}}}{\mathrm{A}_{\mathrm{s}}}+\frac{\mathrm{A}_{\mathrm{c}} \mathrm{d}^{2}}{\mathrm{I}_{\mathrm{s}}}}=\frac{-10,494,386 \mathrm{~N}-\mathrm{m} \times\left(\frac{3,949 \mathrm{~cm}^{2} \times 48.91 \mathrm{~cm}}{3,690,893 \mathrm{~cm}^{4}}\right)}{8.691+\frac{3,949 \mathrm{~cm}^{2}}{1,397 \mathrm{~cm}^{2}}+\frac{3,949 \mathrm{~cm}^{2} \times(48.91 \mathrm{~cm})^{2}}{3,690,893 \mathrm{~cm}^{4}}}$

$N_{c}(t)=-3,900,785 N$

$\mathrm{N}_{\mathrm{s}}(\mathrm{t})=-\mathrm{N}_{\mathrm{c}}(\mathrm{t})=-(-3,900,785 \mathrm{~N})=3,900,785 \mathrm{~N}$

$M_{c}(t)=\frac{n_{N}(t)+\frac{A_{c}}{A_{s}}}{\frac{I_{c}}{I_{s}} \times\left[n_{N}(t)+\frac{A_{c}}{A_{s}}\right]+n_{M}(t) \times\left[n_{N}(t)+\frac{A_{c}}{A_{s}}+\frac{A_{c} d^{2}}{I_{s}}\right]} \times M \frac{I_{c}}{I_{s}}$

$=\frac{8.691+\frac{3,949}{1,397}}{\frac{594,493}{3,690,893}\left[8.691+\frac{3,949}{1,397}\right]+8.691 \times\left[8.691+\frac{3,949}{1,397}+\frac{3,949 \times(48.91)^{2}}{3,690,893}\right]} \times \mathrm{M} \frac{594,493}{3,690,893}$

$M_{c}(t)=0.0149 \times M=0.0149 \times(-10,494,386 N-m)=-156,760 N-m$ 


$$
\begin{aligned}
& M_{s}(t)=M-M_{c}(t)-N_{c}(t) \times d \\
& =(-10,494,386 N-m)-(-156,760 N-m)-(-3,900,785 N) \times 48.91 \mathrm{~cm} \\
& M_{s}(t)=-8,429,752 N-m
\end{aligned}
$$

\section{Stress due to creep and shrinkage}

$$
\begin{aligned}
& \mathrm{f}_{\mathrm{st}}(\mathrm{t})=\frac{\sum \mathrm{N}_{\mathrm{c}}(\mathrm{t})}{\mathrm{A}_{\mathrm{s}}+\mathrm{A}_{\mathrm{c}} / \mathrm{n}} \pm \frac{\sum \mathrm{M}_{\mathrm{c}}(\mathrm{t})}{\mathrm{Sx}_{4}} \\
& =\frac{(3,690,893+3,900,785) \mathrm{N}}{1,397 \mathrm{~cm}^{2}+3,949 \mathrm{~cm}^{2} / 8.762} \pm \frac{(144,782+156,760) \mathrm{N}-\mathrm{m}}{65,008 \mathrm{~cm}^{3}}=466 \mathrm{~N} / \mathrm{cm}^{2} \\
& \mathrm{f}_{\mathrm{sb}}(\mathrm{t})=\frac{\sum \mathrm{N}_{\mathrm{c}}(\mathrm{t})}{\mathrm{A}_{\mathrm{s}}+\mathrm{A}_{\mathrm{c}} / \mathrm{n}} \pm \frac{\sum \mathrm{M}_{\mathrm{c}}(\mathrm{t})}{\mathrm{Sx}_{3}} \\
& =\frac{(-3,690,893-3,900,785) \mathrm{N}}{1,397 \mathrm{~cm}^{2}+3,949 \mathrm{~cm}^{2} / 8.762} \pm \frac{(-144,782-156,760) \mathrm{N}-\mathrm{m}}{101,191 \mathrm{~cm}^{3}}=-4,404 \mathrm{~N} / \mathrm{cm}^{2} \\
& \mathrm{f}_{\mathrm{cb}}(\mathrm{t})=\frac{\sum \mathrm{N}_{\mathrm{c}}(\mathrm{t})}{\mathrm{A}_{\mathrm{c}}+\mathrm{A}_{\mathrm{s}} \times \mathrm{n}} \pm \frac{\sum \mathrm{M}_{\mathrm{c}}(\mathrm{t})}{\mathrm{Sx}_{9}} \\
& =\frac{(-3,690,893-3,900,785) \mathrm{N}}{3,949 \mathrm{~cm}^{2}+1,397 \mathrm{~cm}^{2} \times 8.762} \pm \frac{(-144,782-156,760) \mathrm{N}-\mathrm{m}}{701,189 \mathrm{~cm}^{3}}=-512 \mathrm{~N} / \mathrm{cm}^{2} \\
& \mathrm{f}_{\mathrm{ct}}(\mathrm{t})=\mathrm{N} / \mathrm{A}
\end{aligned}
$$

where:

$\sum \mathrm{N}_{\mathrm{c}}(\mathrm{t})=$ sum of axial forces in concrete due to both creep and shrinkage

$\sum \mathrm{M}_{\mathrm{c}}(\mathrm{t})=$ sum of bending moment in concrete due to both creep and shrinkage

$$
\mathrm{n}=\mathrm{n}_{3}=\text { modular ratio at three days }
$$

\section{Creep and shrinkage: Phase 2}

\section{Initial time of loading: $t_{0}=31$-day}

The time of loading is assumed to start on the 31st day, after the bottom concrete (c1) has cured. At this time, the forms, rebar, and internal components of the slab are already installed; 31 days also marks the final time for creep and shrinkage, Phase 1. 


\section{Final time of loading: $t=59-$ day}

The duration of this phase $(3+28+28=59$-day) represents the period of time from casting through the curing process. The slab weight is transmitted to the steel beam with the bottom flange encased in concrete. In this phase, composite action is not provided by the slab (c2). Most of the concrete strength gain will occur before 28 days, but the duration of this phase was assumed to be 28 days because this is an acceptable time to start locating the superimposed loads to the slab, induced by external components (as analyzed in Load Stage 3; see the previous stress computation section).

For this example, the compression stresses at the bottom of the concrete $\left(f_{c b}\right)$ were reduced from $886 \mathrm{~N} / \mathrm{cm}^{2}$ (Load Stage 3) to $571 \mathrm{~N} / \mathrm{cm}^{2}$ (Load Stage 4), as seen in Table 7. This noteworthy reduction occurs because superimposed dead loads decrease the compression stresses at the bottom region of the beam. If the load is reduced, then creep deformations will also be reduced for subsequent phases. Therefore, it is acceptable to set at this loading stage the final creep contribution due to concrete at the bottom flange. Loading Stage 3 will consider the creep and shrinkage effects of the slab (c2), which will be added by superposition, accounting for load sense (relaxation or compression).

\section{Loading}

The loads acting in this phase are:

$$
\mathrm{F}_{\text {Release }}+\mathrm{w}_{\mathrm{g}}+\mathrm{w}_{\mathrm{c} 1}+\mathrm{w}_{\mathrm{c} 2}+\mathrm{w}_{\mathrm{C} 3}+\mathrm{W}_{\text {Diap. }}
$$

where:

$\mathrm{w}_{\mathrm{c} 2}=$ weight of concrete slab.

$\mathrm{w}_{\mathrm{c} 3}=$ weight of concrete encasing the web of the steel beam. $\mathrm{W}_{\text {Diap. }}=$ weight of concrete diaphragm.

The bending moment produced by the loads is:

$$
\begin{aligned}
& \mathrm{M}_{\text {Phase } 2}=(-10,494,386+3,382,460+753,818+144,433) \mathrm{N}-\mathrm{m} \\
& \mathrm{M}_{\text {Phase } 2}=6,213,675 \mathrm{~N}-\mathrm{m}
\end{aligned}
$$




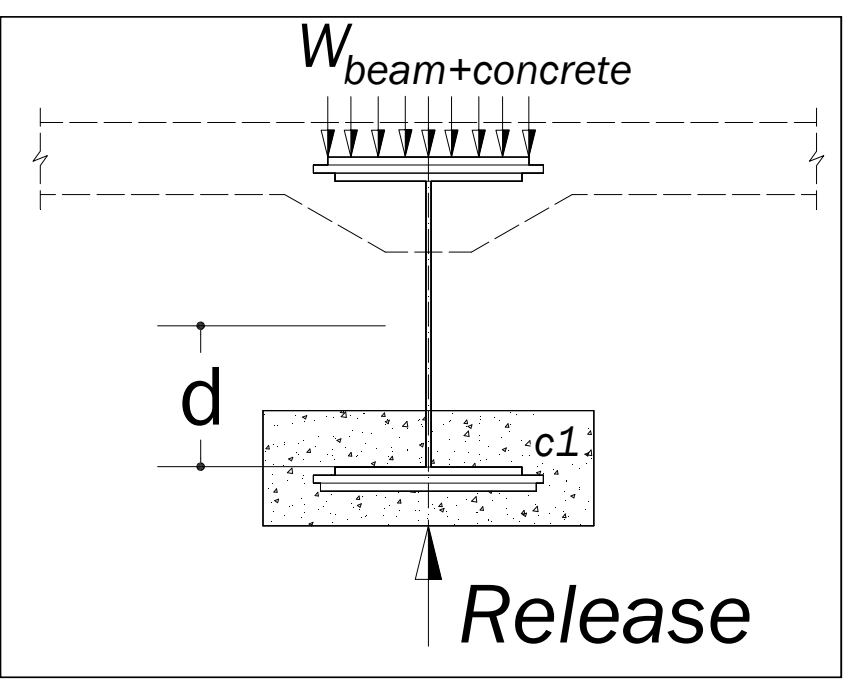

Figure 20. Loads and element sections considered for Phase 2 of creep and shrinkage.

\section{Properties of elements}

For this phase, the individual inertias for the steel beam $\left(\mathrm{I}_{\mathrm{S}}\right)$ and the concrete block at the bottom flange $\left(\mathrm{I}_{\mathrm{all1}}\right)$ with respect to its centroidal axis are considered. The concrete stress for the initial loading condition $\left(\mathrm{t}_{0}=\right.$ 31-day) is assumed as $\mathrm{f}_{\mathrm{Ci}}^{\prime}=1.0 \mathrm{f}_{\mathrm{C}}^{\prime}$.

\section{Creep and shrinkage deflections}

For $t_{o}=31$-day:

$$
\begin{aligned}
& \mathrm{f}_{\mathrm{ci}}=1.0 \mathrm{f}_{\mathrm{c}}^{\prime}=(1.0)\left(5,150 \mathrm{~N} / \mathrm{cm}^{2}\right)=5,150 \mathrm{~N} / \mathrm{cm}^{2} \\
& \mathrm{E}_{\mathrm{c}\left(\mathrm{t}_{\mathrm{o}}\right)}=0.043 \times \mathrm{w}_{\mathrm{c}}^{\prime 1.5} \sqrt{\mathrm{f}_{\mathrm{ci}}^{\prime}}=0.043 \times\left(2,400 \mathrm{~kg} / \mathrm{m}^{3}\right)^{1.5} \sqrt{51.50 \mathrm{MPa}} \\
& \mathrm{E}_{\mathrm{c}\left(\mathrm{t}_{\mathrm{o}}\right)}=36,282 \mathrm{MPa}=3,628,181 \mathrm{~N} / \mathrm{cm}^{2}
\end{aligned}
$$

The creep coefficient at any time is found with Equation 10:

$$
C_{t}=C_{u} \frac{t^{0.6}}{10+t^{0.6}} \times \lambda_{1} \times \lambda_{2}=2.35\left[\frac{(59)^{0.6}}{10+(59)^{0.6}}\right](0.675)(0.835)=0.876
$$

where: 


$$
\begin{aligned}
& \lambda_{1}=1.25\left(\mathrm{t}_{\mathrm{o}}^{-0.118}\right)=1.25(31)^{-0.118}=0.675 \\
& \lambda_{2}=1.27-0.0067 \mathrm{H}=1.27-0.0067(65)=0.835
\end{aligned}
$$

The creep core $\Gamma\left(t_{0}, t\right)$ is computed with Equation 11:

$$
\Gamma\left(t_{0}, t\right)=\frac{E_{c\left(t_{0}\right)}}{E_{c 28}}+C_{t}=\frac{3,628,181 \mathrm{~N} / \mathrm{cm}^{2}}{3,628,900 \mathrm{~N} / \mathrm{cm}^{2}}+0.876=1.876
$$

The adjusted modular ratios are defined as:

$$
\begin{aligned}
& \mathrm{n}_{\left(\mathrm{t}_{0}\right)}=\frac{\mathrm{E}_{\mathrm{s}}}{\mathrm{E}_{\mathrm{c}}\left(\mathrm{t}_{0}\right)}=\frac{20,110,500 \mathrm{~N} / \mathrm{cm}^{2}}{3,628,181 \mathrm{~N} / \mathrm{cm}^{2}}=5.543 \\
& \mathrm{n}_{28}=\frac{\mathrm{E}_{\mathrm{s}}}{\mathrm{E}_{\mathrm{c} 28}}=\frac{20,110,500 \mathrm{~N} / \mathrm{cm}^{2}}{3,628,900 \mathrm{~N} / \mathrm{cm}^{2}}=5.542
\end{aligned}
$$

Using Equation 12, the modular ratio, $\mathrm{n}_{\mathrm{N}}(\mathrm{t})$, considering creep effects, is found next.

$$
\begin{aligned}
& \mathrm{n}_{\mathrm{N}}(\mathrm{t})=\frac{1.876 \times\left(\frac{3,949}{1,397}+\frac{3,949 \times(48.91)^{2}}{3,690,893}\right)+[(1-0.2) \times 1.876+0.2] \times 5.543}{5.543+\frac{3,949}{1,397}+\frac{3,949 \times(48.91)^{2}}{3,690,893}-5.542 \times 0.2 \times(1.876-1)} \times 5.542 \\
& \mathrm{n}_{\mathrm{N}}(\mathrm{t})=10.868
\end{aligned}
$$

where:

$$
\begin{aligned}
\mathrm{A}_{\mathrm{c}}= & 3,949 \mathrm{~cm}^{2} \\
\mathrm{~A}_{\mathrm{s}}= & 1,397 \mathrm{~cm}^{2} \\
\mathrm{~d}= & 48.91 \mathrm{~cm}=\text { distance between centers of gravity of steel and } \\
& \text { concrete } \\
\alpha= & 0.2, \text { determines the stress relaxation path due to creep } \\
\mathrm{I}_{\mathrm{s}}= & 3,690,893 \mathrm{~cm}^{4} \\
\mathrm{n}_{\mathrm{i}}= & \mathrm{n}_{\text {(to) }}=5.543 \\
\mathrm{n}_{28}= & 5.542
\end{aligned}
$$

The axial force in the concrete is then found with Equation 13: 


$$
\begin{aligned}
& N_{c}(t)=\frac{M\left(\frac{A_{c} d}{I_{s}}\right)}{n_{N}(t)+\frac{A_{c}}{A_{s}}+\frac{A_{c} d^{2}}{I_{s}}}=10.868+\frac{3,949 \mathrm{~cm}^{2}}{1,397 \mathrm{~cm}^{2}}+\frac{3,949 \mathrm{~cm}^{2} \times(48.91 \mathrm{~cm})^{2}}{3,690,893 \mathrm{~cm}^{4}} \\
& N_{c}(t)=-2,000,218 \mathrm{~N}
\end{aligned}
$$

By the equilibrium of axial forces and using Equation 4,

$$
N_{s}(t)=-N_{c}(t)=-(-2,000,218 N)=2,000,218 N
$$

The constant values of $\beta(t)$ and $\gamma$ and are found with Equations 14 and 15, respectively.

$$
\begin{aligned}
& \beta(t)=\underbrace{n_{s}+\frac{A_{c}}{A_{s}}}_{n_{N}(t)+\frac{A_{c}}{A_{s}}} \frac{n_{N}(t)+\frac{A_{c}}{A_{s}}+\frac{A_{c} d^{2}}{I_{s}}}{\frac{I_{s}}{I_{s}}\left(n_{i}+\frac{A_{c}}{A_{s}}\right)+n_{i}\left(n_{i}+\frac{A_{c}}{A_{s}}+\frac{A_{c} d^{2}}{I_{s}}\right)} \\
& =\frac{5.543+\frac{3,949}{1,397}}{10.868+\frac{3,949}{1,397} \times \frac{10.868+\frac{3,949}{1,397}+\frac{3,949 \times(48.91)^{2}}{3,690,893}}{\frac{594,493}{3,690,893}\left(5.543+\frac{3,949}{1,397}\right)+5.543\left(5.543+\frac{3,949}{1,397}+\frac{3,949 \times(48.91)^{2}}{3,690,893}\right)}}
\end{aligned}
$$

$\beta(t)=0.160$

$$
\gamma=\frac{5.543\left(5.543+\frac{3,949}{1,397}+\frac{3,949 \times(48.91)^{2}}{3,690,893}\right)}{\frac{594,493}{3,690,893}\left(5.543+\frac{3,949}{1,397}\right)+5.543\left(5.543+\frac{3,949}{1,397}+\frac{3,949 \times(48.91)^{2}}{3,690,893}\right)}=0.978
$$

The bending moment modular ratio is found next with Equation 16:

$$
\mathrm{n}_{\mathrm{M}}(\mathrm{t})=\frac{1.876-0.2(1.876-1) \times 0.978}{1-5.542 \times 0.2(1.876-1) \times 0.160} \times 5.542=11.188
$$

where:

$$
\begin{aligned}
\alpha \mathrm{M}= & 0.2, \text { determines the stress relaxation path due to creep and is } \\
& \text { similar to } \alpha .
\end{aligned}
$$




$$
I_{C}=594,493 \mathrm{~cm}^{4}
$$

The moment in the concrete is found with Equation 17:

$$
\begin{aligned}
& M_{c}(t)=\frac{n_{N}(t)+\frac{A_{c}}{A_{s}}}{\frac{I_{c}}{I_{s}} \times\left[n_{N}(t)+\frac{A_{c}}{A_{s}}\right]+n_{M}(t) \times\left[n_{N}(t)+\frac{A_{c}}{A_{s}}+\frac{A_{c} d^{2}}{I_{s}}\right]} \times M \frac{I_{c}}{I_{s}} \\
& =\frac{10.868+\frac{3,949}{1,397}}{\frac{594,493}{3,690,893}\left[10.868+\frac{3,949}{1,397}\right]+11.188 \times\left[10.868+\frac{3,949}{1,397}+\frac{3,949 \times(48.91)^{2}}{3,690,893}\right]} \times \mathrm{M} \frac{594,493}{3,690,893} \\
& M_{c}(t)=0.0120 \times M=0.0120 \times(-6,213,675 N-m)=-74,468 N-m
\end{aligned}
$$

The moment in the steel, $M_{s}(t)$, is found using Equation 5:

$$
\begin{aligned}
& M_{s}(t)=M-M_{c}(t)-N_{c}(t) \times d \\
& =(-6,213,675 N-m)-(-74,468 N-m)-(-2,000,218 N) \times 48.91 \mathrm{~cm} \\
& M_{s}(t)=-5,160,901 N-m
\end{aligned}
$$

The axial forces produced by shrinkage are found with Equation 18:

$$
\begin{aligned}
& \mathrm{n}_{\mathrm{N}}(\mathrm{t})=\mathrm{n}_{28} \times\left[(1-\alpha) \times \Gamma\left(\mathrm{t}_{\mathrm{o}}, \mathrm{t}\right)+\alpha\right] \\
& \mathrm{n}_{\mathrm{N}}(\mathrm{t})=5.542 \times[(1-0.2) \times 1.876+0.2]=9.425
\end{aligned}
$$

As stated earlier,

$$
\mathrm{n}_{\mathrm{N}}(\mathrm{t})=\mathrm{n}_{\mathrm{M}}(\mathrm{t})=9.425
$$

The axial forces and moments for shrinkage are found in the same way as for creep. 
$\mathrm{N}_{\mathrm{c}}(\mathrm{t})=\frac{\mathrm{M}\left(\frac{\mathrm{A}_{\mathrm{c}} \mathrm{d}}{\mathrm{I}_{\mathrm{s}}}\right)}{\mathrm{n}_{\mathrm{N}}(\mathrm{t})+\frac{\mathrm{A}_{\mathrm{c}}}{\mathrm{A}_{\mathrm{s}}}+\frac{\mathrm{A}_{\mathrm{c}} \mathrm{d}^{2}}{\mathrm{I}_{\mathrm{s}}}}=\frac{-6,213,675 \mathrm{~N}-\mathrm{m} \times\left(\frac{3,949 \mathrm{~cm}^{2} \times 48.91 \mathrm{~cm}}{3,690,893 \mathrm{~cm}^{4}}\right)}{9.425+\frac{3,949 \mathrm{~cm}^{2}}{1,397 \mathrm{~cm}^{2}}+\frac{3,949 \mathrm{~cm}^{2} \times(48.91 \mathrm{~cm})^{2}}{3,690,893 \mathrm{~cm}^{4}}}$

$\mathrm{N}_{\mathrm{c}}(\mathrm{t})=2,195,190 \mathrm{~N}$

$\mathrm{N}_{\mathrm{s}}(\mathrm{t})=-\mathrm{N}_{\mathrm{c}}(\mathrm{t})=(-2,195,190 \mathrm{~N})=2,195,190 \mathrm{~N}$

$M_{c}(t)=\frac{n_{N}(t)+\frac{A_{c}}{A_{s}}}{\frac{I_{c}}{I_{s}} \times\left[n_{N}(t)+\frac{A_{c}}{A_{s}}\right]+n_{M}(t) \times\left[n_{N}(t)+\frac{A_{c}}{A_{s}}+\frac{A_{c} d^{2}}{I_{s}}\right]} \times M \frac{I_{c}}{I_{s}}$

$=\frac{9.425+\frac{3,949}{1,397}}{\frac{594,493}{3,690,893}\left[9.425+\frac{3,949}{1,397}\right]+9.425 \times\left[9.425+\frac{3,949}{1,397}+\frac{3,949 \times(48.91)^{2}}{3,690,893}\right]} \times \mathrm{M} \frac{594,493}{3,690,893}$

$M_{c}(t)=0.0139 \times M=0.0139 \times(-6,213,675 \mathrm{~N}-\mathrm{m})=-86,619 \mathrm{~N}-\mathrm{m}$

$\mathrm{M}_{\mathrm{s}}(\mathrm{t})=\mathrm{M}-\mathrm{M}_{\mathrm{c}}(\mathrm{t})-\mathrm{N}_{\mathrm{c}}(\mathrm{t}) \times \mathrm{d}$

$=(-6,213,675 \mathrm{~N}-\mathrm{m})-(-86,619 \mathrm{~N}-\mathrm{m})-(-2,195,190 \mathrm{~N}) \times 48.91 \mathrm{~cm}$

$M_{s}(t)=-5,053,389 \mathrm{~N}-\mathrm{m}$

\section{Stress due to creep and shrinkage}

$$
\begin{aligned}
& \mathrm{f}_{\mathrm{st}}(\mathrm{t})=\frac{\sum \mathrm{N}_{\mathrm{c}}(\mathrm{t})}{\mathrm{A}_{\mathrm{s}}+\mathrm{A}_{\mathrm{c}} / \mathrm{n}} \pm \frac{\sum \mathrm{M}_{\mathrm{c}}(\mathrm{t})}{\mathrm{Sx}_{6}} \\
& =\frac{(4,954,020+4,965,473) \mathrm{N}}{1,397 \mathrm{~cm}^{2}+3,949 \mathrm{~cm}^{2} / 5.542} \pm \frac{(223,418+224,142) \mathrm{N}-\mathrm{m}}{65,780 \mathrm{~cm}^{3}}=246 \mathrm{~N} / \mathrm{cm}^{2} \\
& \mathrm{f}_{\mathrm{sb}}(\mathrm{t})=\frac{\sum \mathrm{N}_{\mathrm{c}}(\mathrm{t})}{\mathrm{A}_{\mathrm{s}}+\mathrm{A}_{\mathrm{c}} / \mathrm{n}} \pm \frac{\sum \mathrm{M}_{\mathrm{c}}(\mathrm{t})}{\mathrm{Sx}_{5}} \\
& =\frac{(-2,000,218-2,195,190) \mathrm{N}}{1,397 \mathrm{~cm}^{2}+3,949 \mathrm{~cm}^{2} / 5.542} \pm \frac{(-74,468-86,619) \mathrm{N}-\mathrm{m}}{121,550 \mathrm{~cm}^{3}}=2,122 \mathrm{~N} / \mathrm{cm}^{2}
\end{aligned}
$$




$$
\begin{aligned}
& \mathrm{f}_{\mathrm{cb}}(\mathrm{t})=\frac{\sum \mathrm{N}_{\mathrm{c}}(\mathrm{t})}{\mathrm{A}_{\mathrm{c}}+\mathrm{A}_{\mathrm{s}} \times \mathrm{n}} \pm \frac{\sum \mathrm{M}_{\mathrm{c}}(\mathrm{t})}{\mathrm{Sx}_{10}} \\
& =\frac{(-2,000,218-2,195,190) \mathrm{N}}{3,949 \mathrm{~cm}^{2}+1,397 \mathrm{~cm}^{2} \times 5.542} \pm \frac{(-74,468-86,619) \mathrm{N}-\mathrm{m}}{520,335 \mathrm{~cm}^{3}}=-390 \mathrm{~N} / \mathrm{cm}^{2} \\
& \mathrm{f}_{\mathrm{ct}}(\mathrm{t})=\mathrm{N} / \mathrm{A}
\end{aligned}
$$

\section{Creep and shrinkage: Phase 3}

Initial time of loading: $t_{0}=\mathbf{2 8}$-day

The initial time of loading is assumed as 28 days (the period in which the concrete slab has cured). The superimposed dead loads are applied at this initial time. For this phase, the slab is providing composite action to the pre-flex system.

\section{Final time of loading: $t=40,000$-day}

The final time of analysis is the service life of the beam. For illustration purposes, a value of 40,000 days has been assumed. The values calculated during the period of loading will be added to those obtained in the previous creep and shrinkage phase (Phase 2) by superposition.

\section{Loading}

The loads acting in this phase are only superimposed dead loads (WSDL). The bending moment produced by the loads is:

$$
\mathrm{M}_{\text {Phase } 3}=2,019,173 \mathrm{~N}-\mathrm{m}
$$

\section{Properties of elements}

The steel beam and the concrete $\mathrm{cl}$ are treated as a transformed beam section. Figure 21 shows the transformed section upside down in order to apply the equations of Giacomo and Maninni directly. The concrete stress for the initial loading condition ( $\mathrm{t}_{0}=28$-day) is assumed as $\mathrm{f}_{\mathrm{ci}}^{\prime}=1.0 \mathrm{f}_{\mathrm{c}}^{\prime}$. 


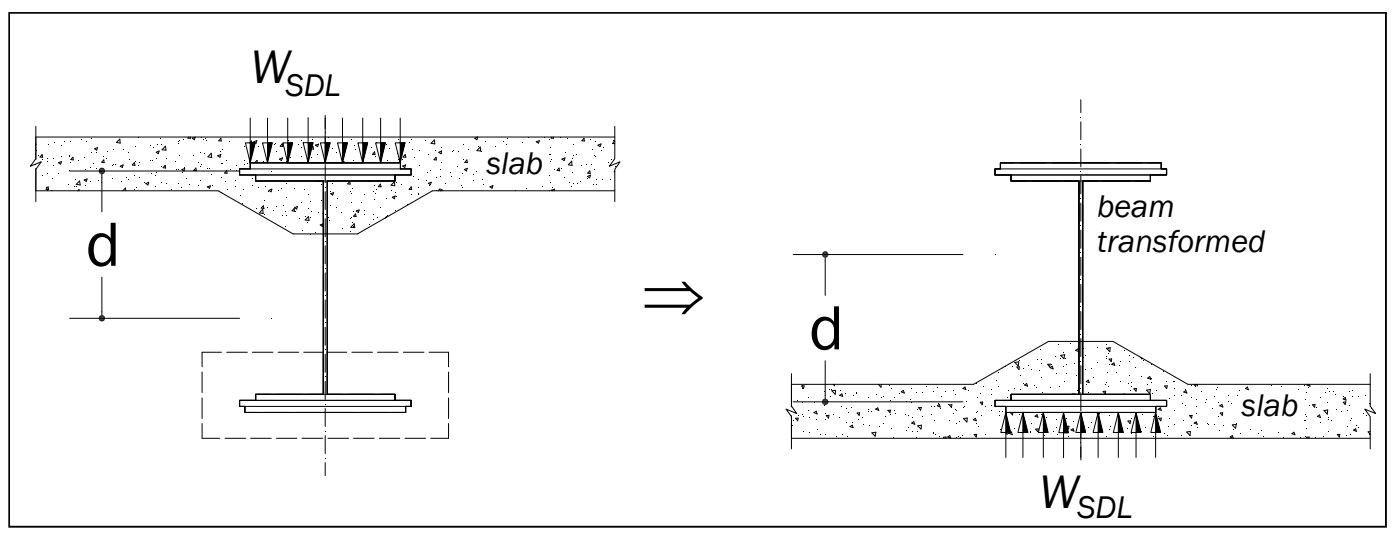

Figure 21. Loads and element sections considered for Phase 3 of creep and shrinkage.

\section{Creep and shrinkage effects}

For $t_{o}=28$-day,

$$
\begin{aligned}
& \mathrm{f}_{\mathrm{ci}}=1.0 \mathrm{f}_{\mathrm{c}}^{\prime}=1.0\left(5,15 \mathrm{O}^{\mathrm{N}} / \mathrm{cm}^{2}\right)=5,15 \mathrm{O}^{\mathrm{N}} / \mathrm{cm}^{2} \\
& \mathrm{E}_{\mathrm{c}\left(\mathrm{t}_{\mathrm{o}}\right)}=0.043 \times \mathrm{w}_{\mathrm{c}}^{\prime 1.5} \sqrt{\mathrm{f}_{\mathrm{ci}}^{\prime}}=0.043\left(2,400 \mathrm{~kg} / \mathrm{m}^{3}\right)^{1.5} \times \sqrt{51.50 \mathrm{MPa}} \\
& \mathrm{E}_{\mathrm{c}\left(\mathrm{t}_{\mathrm{o}}\right)}=36,282 \mathrm{MPa}=3,628,181 \mathrm{~N} / \mathrm{cm}^{2}
\end{aligned}
$$

The creep coefficient at any time, $C_{t}$, can be calculated with Equation 10.

$$
\mathrm{C}_{\mathrm{t}}=\mathrm{C}_{\mathrm{u}} \frac{\mathrm{t}^{\mathrm{o.6}}}{10+\mathrm{t}^{0.6}} \times \lambda_{1} \times \lambda_{2}=2.35\left[\frac{(40,000)^{0.6}}{10+(40,000)^{0.6}}\right](0.844)(0.835)=1.626
$$

where:

$$
\begin{aligned}
& \lambda_{1}=1.25\left(\mathrm{t}_{\mathrm{o}}^{-0.118}\right)=1.25(28)^{-0.118}=0.844 \text { for moist cured concrete. } \\
& \lambda_{2}=1.27-0.0067 \mathrm{H}=1.27-0.0067(65)=0.835
\end{aligned}
$$

The creep core $\Gamma\left(t_{o}, t\right)$ is computed with Equation 11.

$$
\Gamma\left(t_{0}, t\right)=\frac{E_{c\left(t_{o}\right)}}{E_{c 28}}+C_{t}=\frac{3,628,181 \mathrm{~N} / \mathrm{cm}^{2}}{3,628,900 \mathrm{~N} / \mathrm{cm}^{2}}+1.626=2.626
$$

The adjusted modular ratios are: 


$$
\begin{aligned}
& \mathrm{n}_{\left(\mathrm{t}_{0}\right)}=\frac{\mathrm{E}_{\mathrm{s}}}{\mathrm{E}_{\mathrm{c}}(\mathrm{t})}=\frac{20,110,500 \mathrm{~N} / \mathrm{cm}^{2}}{3,628,181 \mathrm{~N} / \mathrm{cm}^{2}}=5.543 \\
& \mathrm{n}_{28}=\frac{\mathrm{E}_{\mathrm{s}}}{\mathrm{E}_{\mathrm{c} 28}}=\frac{20,110,500 \mathrm{~N} / \mathrm{cm}^{2}}{3,628,900 \mathrm{~N} / \mathrm{cm}^{2}}=5.542
\end{aligned}
$$

Using Equation 12, the modular ratio, $\mathrm{n}_{\mathrm{N}}(\mathrm{t})$, considering creep effects, is found next.

$$
\begin{aligned}
& \mathrm{n}_{\mathrm{N}}(\mathrm{t})=\frac{2.626 \times\left(\frac{7,404}{2,109}+\frac{7,404 \times(71.55)^{2}}{4,951,048}\right)+[(1-0.2) \times 2.626+0.2] \times 5.543}{5.543+\frac{7,404}{2,109}+\frac{7,404 \times(71.55)^{2}}{4,951,048}-5.542 \times 0.2 \times(2.626-1)} \times 5.542 \\
& \mathrm{n}_{\mathrm{N}}(\mathrm{t})=15.642
\end{aligned}
$$

where:

$$
\begin{aligned}
\mathrm{A}_{\mathrm{c}}= & \mathrm{A}_{\mathrm{c} 2}=7,404 \mathrm{~cm}^{2} \\
\mathrm{~A}_{\mathrm{s}}= & \mathrm{A}_{\mathrm{en} 28}=2,109 \mathrm{~cm}^{2} \\
\mathrm{~d}= & 71.55 \mathrm{~cm}=\text { distance between centers of gravity of steel and } \\
& \text { concrete. } \\
\alpha= & 0.2, \text { determines the stress relaxation path due to creep. } \\
\mathrm{I}_{\mathrm{s}}= & \mathrm{Ix}_{2}=4,951,048 \mathrm{~cm}^{4} \\
\mathrm{n}_{\mathrm{i}}= & \mathrm{n}_{(\mathrm{to})}=5.543 \\
\mathrm{n}_{28}= & 5.542
\end{aligned}
$$

The axial force in the concrete is then found with Equation 13.

$$
\mathrm{N}_{\mathrm{c}}(\mathrm{t})=\frac{-2,019,173 \mathrm{~N}-\mathrm{m} \times\left(\frac{7,404 \mathrm{~cm}^{2} \times 71.55 \mathrm{~cm}}{4,951,048 \mathrm{~cm}^{4}}\right)}{15.642+\frac{7,404 \mathrm{~cm}^{2}}{2,109 \mathrm{~cm}^{2}}+\frac{7,404 \mathrm{~cm}^{2} \times(71.55 \mathrm{~cm})^{2}}{4,951,048 \mathrm{~cm}^{4}}}=-805,883 \mathrm{~N}
$$

By the equilibrium of axial forces and using Equation 4,

$$
\mathrm{N}_{\mathrm{s}}(\mathrm{t})=-\mathrm{N}_{\mathrm{c}}(\mathrm{t})=(-805,883 \mathrm{~N})=805,883 \mathrm{~N}
$$


The constant values of $\beta(t)$ and $\gamma$ and are found with Equations 14 and 15, respectively.

$$
\begin{aligned}
& \beta(t)=\frac{5 \cdot 543+\frac{7,404}{2,109}}{15.642+\frac{7,404}{2,109}} \times \frac{15 \cdot 642+\frac{7,404}{2,109}+\frac{7,404 \times(71.55)^{2}}{3,690,893}}{\frac{839,685}{4,951,048}\left(8.764+\frac{7,404}{2,109}\right)+5.543\left(5.543+\frac{7,404}{2,109}+\frac{7,404 \times(71.55)^{2}}{4,951,048}\right)} \\
& \beta(t)=0.135 \\
& \gamma=\frac{5 \cdot 543\left(5.543+\frac{7,404}{2,109}+\frac{7,404 \times(71.55)^{2}}{4,951,048}\right)}{\frac{839,685}{4,951,048}\left(5.543+\frac{7,404}{2,109}\right)+5.543\left(5.543+\frac{7,404}{2,109}+\frac{7,404 \times(71.55)^{2}}{4,951,048}\right)}=0.984
\end{aligned}
$$

The bending moment modular ratio is found next with Equation 16.

$$
\mathrm{n}_{\mathrm{M}}(\mathrm{t})=\frac{2.626-0.2(2.626-1) \times 0.984}{1-5.542 \times 0.2 \times(2.626-1) \times 0.135} \times 5.542=16.873
$$

where:

$$
I_{c}=839,685 \mathrm{~cm}^{4}
$$

The moment in the concrete is found with Equation 17.

$$
\begin{aligned}
& M_{c}(t)=\frac{n_{N}(t)+\frac{A_{c}}{A_{s}}}{\frac{I_{c}}{I_{s}} \times\left[n_{N}(t)+\frac{A_{c}}{A_{s}}\right]+n_{M}(t) \times\left[n_{N}(t)+\frac{A_{c}}{A_{s}}+\frac{A_{c} d^{2}}{I_{s}}\right]} \times M \frac{I_{c}}{I_{s}} \\
& =\frac{15.642+\frac{7,404}{2,109}}{\frac{839,685}{4,951,048}\left[15.642+\frac{7,404}{2,109}\right]+16.873 \times\left[15.642+\frac{7,404}{2,109}+\frac{7,404 \times(71.55)^{2}}{4,951,048}\right]} \times M \frac{839,685}{4,951,048} \\
& M_{c}(t)=0.0071 \times M=0.0071 \times(-2,019,173 N-m)=-14,397 \mathrm{~N}-\mathrm{m}
\end{aligned}
$$

The moment in the steel, $M_{s}(t)$, is found using Equation 5: 


$$
\begin{aligned}
& M_{s}(t)=M-M_{c}(t)-N_{c}(t) \times d \\
& =(-2,019,173 N-m)-(-14,397 N-m)-(-805,883 N) \times 71.55 \mathrm{~cm} \\
& M_{s}(t)=-1,428,167 N-m
\end{aligned}
$$

The axial forces produced by shrinkage are found with Equation 18.

$$
\begin{aligned}
& \mathrm{n}_{\mathrm{N}}(\mathrm{t})=\mathrm{n}_{28} \times\left[(1-\alpha) \times \Gamma\left(\mathrm{t}_{\mathrm{o}}, \mathrm{t}\right)+\alpha\right] \\
& \mathrm{n}_{\mathrm{N}}(\mathrm{t})=5.542 \times[(1-0.2) \times 2.626+0.2]=12.751
\end{aligned}
$$

As stated earlier,

$$
\mathrm{n}_{\mathrm{N}}(\mathrm{t})=\mathrm{n}_{\mathrm{M}}(\mathrm{t})=12.751
$$

The shrinkage axial forces and moments are found as follows:

$\mathrm{N}_{\mathrm{c}}(\mathrm{t})=\frac{-2,019,173 \mathrm{~N}-\mathrm{m} \times\left(\frac{7,404 \mathrm{~cm}^{2} \times 71.55 \mathrm{~cm}}{4,951,048 \mathrm{~cm}^{4}}\right)}{12.571+\frac{7,404 \mathrm{~cm}^{2}}{2,109 \mathrm{~cm}^{2}}+\frac{7,404 \mathrm{~cm}^{2} \times(71.55 \mathrm{~cm})^{2}}{4,951,048 \mathrm{~cm}^{4}}}=-903,315 \mathrm{~N}$

$\mathrm{N}_{\mathrm{s}}(\mathrm{t})=-\mathrm{N}_{\mathrm{c}}(\mathrm{t})=-(-903,315 \mathrm{~N})=903,315 \mathrm{~N}$

$M_{c}(t)=\frac{n_{N}(t)+\frac{A_{c}}{A_{s}}}{\frac{I_{c}}{I_{s}} \times\left[n_{N}(t)+\frac{A_{c}}{A_{s}}\right]+n_{M}(t) \times\left[n_{N}(t)+\frac{A_{c}}{A_{s}}+\frac{A_{c} d^{2}}{I_{s}}\right]} \times M \frac{I_{c}}{I_{s}}$
$=\frac{12.751+\frac{7,404}{2,109}}{\frac{839,685}{4,951,048}\left[12.751+\frac{7,404}{2,109}\right]+12.751 \times\left[12.751+\frac{7,404}{2,109}+\frac{7,404 \times(71.55)^{2}}{4,951,048}\right]} \times M \frac{839,685}{4,951,048}$

$M_{c}(t)=0.0090 \times M=0.0090 \times(-2,019,173 \mathrm{~N} \times \mathrm{m})=-18,097 \mathrm{~N}-\mathrm{m}$

$\mathrm{M}_{\mathrm{s}}(\mathrm{t})=\mathrm{M}-\mathrm{M}_{\mathrm{c}}(\mathrm{t})-\mathrm{N}_{\mathrm{c}}(\mathrm{t}) \times \mathrm{d}$

$=(-2,019,173 \mathrm{~N}-\mathrm{m})-(-18,097 \mathrm{~N}-\mathrm{m})-(-903,315 \mathrm{~N})(71.55 \mathrm{~cm})$

$M_{s}(t)=-1,354,755 N-m$ 
Stress due to creep and shrinkage

$$
\begin{aligned}
& \mathrm{f}_{\mathrm{st}}(\mathrm{t})=\frac{\sum \mathrm{N}_{\mathrm{c}}(\mathrm{t})}{\mathrm{A}_{\mathrm{s}}+\mathrm{A}_{\mathrm{c}} / \mathrm{n}} \pm \frac{\sum \mathrm{M}_{\mathrm{c}}(\mathrm{t})}{\mathrm{Sx}_{8}} \\
& =\frac{(-805,883-903,315) \mathrm{N}}{1,397 \mathrm{~cm}^{2}+3,949 \mathrm{~cm}^{2} / 5.542} \pm \frac{(-14,397-18,097) \mathrm{N}-\mathrm{m}}{195,476 \mathrm{~cm}^{3}}=-17 \mathrm{~N} / \mathrm{cm}^{2} \\
& \mathrm{f}_{\mathrm{sb}}(\mathrm{t})=\frac{\sum \mathrm{N}_{\mathrm{c}}(\mathrm{t})}{\mathrm{A}_{\mathrm{s}}+\mathrm{A}_{\mathrm{c}} / \mathrm{n}} \pm \frac{\sum \mathrm{M}_{\mathrm{c}}(\mathrm{t})}{\mathrm{Sx}_{7}} \\
& =\frac{(805,883+903,315) \mathrm{N}}{1,397 \mathrm{~cm}^{2}+3,949 \mathrm{~cm}^{2} / 5.542} \pm \frac{(14,397+18,097) \mathrm{N}-\mathrm{m}}{135,654 \mathrm{~cm}^{3}}=520 \mathrm{~N} / \mathrm{cm}^{2} \\
& \mathrm{f}_{\mathrm{cb}}(\mathrm{t})=\frac{\sum \mathrm{N}_{\mathrm{c}}(\mathrm{t})}{\mathrm{A}_{\mathrm{c}}+\mathrm{A}_{\mathrm{s}} \times \mathrm{n}} \pm \frac{\sum \mathrm{M}_{\mathrm{c}}(\mathrm{t})}{\mathrm{Sx}_{11}} \\
& =\frac{(805,883+903,315) \mathrm{N}}{7,404 \mathrm{~cm}^{2}+2,109 \mathrm{~cm}^{2} \times 5.542} \pm \frac{(14,397+18,097) \mathrm{N}-\mathrm{m}}{639,695 \mathrm{~cm}^{3}}=95 \mathrm{~N} / \mathrm{cm}^{2} \\
& \mathrm{f}_{\mathrm{ct}}(\mathrm{t})=\frac{\sum \mathrm{N}_{\mathrm{c}}(\mathrm{t})}{\mathrm{A}_{\mathrm{c}}+\mathrm{A}_{\mathrm{s}} \times \mathrm{n}} \pm \frac{\sum \mathrm{M}_{\mathrm{c}}(\mathrm{t})}{\mathrm{Sx}_{12}} \\
& =\frac{(-805,883-903,315) \mathrm{N}}{7,404 \mathrm{~cm}^{2}+2,109 \mathrm{~cm}^{2} \times 5.542} \pm \frac{(-14,397-18,097) \mathrm{N}-\mathrm{m}}{864,920 \mathrm{~cm}^{3}}=-93 \mathrm{~N} / \mathrm{cm}^{2}
\end{aligned}
$$

The recently computed creep and shrinkage stresses can be seen in Table 8, where all stresses computed so far are superimposed according to loading stage. As can be seen in the table, the stress checks indicate that the pre-flex beam is adequate at each loading stage. 
Table 8. Stress values including creep and shrinkage stresses.

\begin{tabular}{|c|c|c|c|c|c|c|}
\hline \multirow{2}{*}{$\begin{array}{l}\text { Loading } \\
\text { Stage }\end{array}$} & Load & Moment & $f_{\text {st }}$ & $f_{s b}$ & $f_{c b}$ & $f_{c t}$ \\
\hline & $\mathrm{N} / \mathrm{m}$ & $\mathrm{N} / \mathrm{m}$ & $\mathrm{N} / \mathrm{cm}^{2}$ & $\mathrm{~N} / \mathrm{cm}^{2}$ & $\mathrm{~N} / \mathrm{cm}^{2}$ & $\mathrm{~N} / \mathrm{cm}^{2}$ \\
\hline \multicolumn{2}{|l|}{ Pre-flexion Load: } & $14,372,000$ & $-22,806$ & 22,364 & 0 & 0 \\
\hline \multirow{2}{*}{\multicolumn{3}{|c|}{ Allowable Stress Stage 1: Pre-flex load }} & \multicolumn{2}{|l|}{24,720} & \multicolumn{2}{|l|}{2,060} \\
\hline & & & OK & OK & OK & OK \\
\hline \multicolumn{2}{|l|}{ Release: } & $-14,372,000$ & 22,108 & $-14,203$ & $-2,050$ & 0 \\
\hline Pre-flex Beam: & 19,983 & $3,877,614$ & $-5,965$ & 3,832 & 553 & 0 \\
\hline \multicolumn{2}{|c|}{ Creep \& Shrinkage ( $\mathrm{t}=3$-day): } & $-10,494,386$ & 466 & $-4,404$ & -512 & 0 \\
\hline \multicolumn{3}{|r|}{ Total: } & $-6,196$ & 7,589 & $-2,008$ & 0 \\
\hline \multirow{2}{*}{\multicolumn{3}{|c|}{$\begin{array}{l}\text { Allowable Stress Stage 2: Release and beam self- } \\
\text { weight }\end{array}$}} & \multicolumn{2}{|l|}{24,720} & \multicolumn{2}{|l|}{2,060} \\
\hline & & & OK & OK & OK & OK \\
\hline Diaphragm: & 744 & 144,433 & -222 & 143 & 21 & 0 \\
\hline Slab: & 17,431 & $3,382,460$ & $-5,203$ & 3,343 & 482 & 0 \\
\hline Concrete Web: & 3,885 & 753,818 & $-1,160$ & 745 & 108 & 0 \\
\hline \multicolumn{2}{|c|}{ Creep \& Shrinkage (t = 28-day): } & $-6,213,675$ & 246 & $-2,122$ & -390 & 0 \\
\hline \multicolumn{3}{|r|}{ Total: } & $-12,535$ & 9,698 & $-1,788$ & 0 \\
\hline \multirow{2}{*}{\multicolumn{3}{|c|}{$\begin{array}{l}\text { Allowable Stress Stage 3: Concrete slab, diaphragm, } \\
\text { and concrete web }\end{array}$}} & \multicolumn{2}{|l|}{24,720} & \multicolumn{2}{|l|}{2,060} \\
\hline & & & OK & OK & OK & OK \\
\hline Parapet: & 5,112 & 991,933 & -507 & 731 & 155 & -115 \\
\hline Wearing Surface: & 4,412 & 856,033 & -438 & 631 & 134 & -99 \\
\hline Additional Weight: & 882 & 171,207 & -88 & 126 & 27 & -20 \\
\hline \multicolumn{2}{|c|}{ Creep \& Shrink. ( $t=40,000$-day): } & $2,019,173$ & -17 & 520 & 95 & -93 \\
\hline \multicolumn{3}{|r|}{ Total: } & $-13,585$ & 11,706 & $-1,377$ & -327 \\
\hline \multirow{2}{*}{\multicolumn{3}{|c|}{$\begin{array}{l}\text { Allowable Stress Stage 4: Superimposed loads on } \\
\text { concrete slab }\end{array}$}} & \multicolumn{2}{|l|}{24,720} & \multicolumn{2}{|l|}{2,060} \\
\hline & & & OK & OK & OK & OK \\
\hline Live Load: & & $2,705,000$ & $-1,384$ & 1,994 & 423 & -313 \\
\hline \multicolumn{3}{|r|}{ Total: } & $-14,969$ & 13,700 & -955 & -639 \\
\hline \multirow{2}{*}{\multicolumn{3}{|c|}{ Allowable Stress Stage 5: Live load }} & \multicolumn{2}{|l|}{24,720} & \multicolumn{2}{|l|}{2,060} \\
\hline & & & OK & OK & OK & OK \\
\hline
\end{tabular}




\section{Shear Resistance}

In pre-flex beams, only the steel web is considered to provide resistance to shear forces. The permissible stresses for shear may be increased with the same ratio as the stresses for bending. The proposed allowable shear stress can be taken as $0.55 \mathrm{fy}$. Two checks must be made: (1) pre-flexion load and (2) shear produced by external loads. For load rating, the shear stress due to pre-flexion is not considered because it is assumed that $100 \%$ of the shear load is released and permanent shear deformations are not present.

The horizontal shear is resisted by shear connectors consisting of shear studs or horseshoes (Figure 22.) Manufacturers provide technical specifications for the capacity and installation of these connectors.

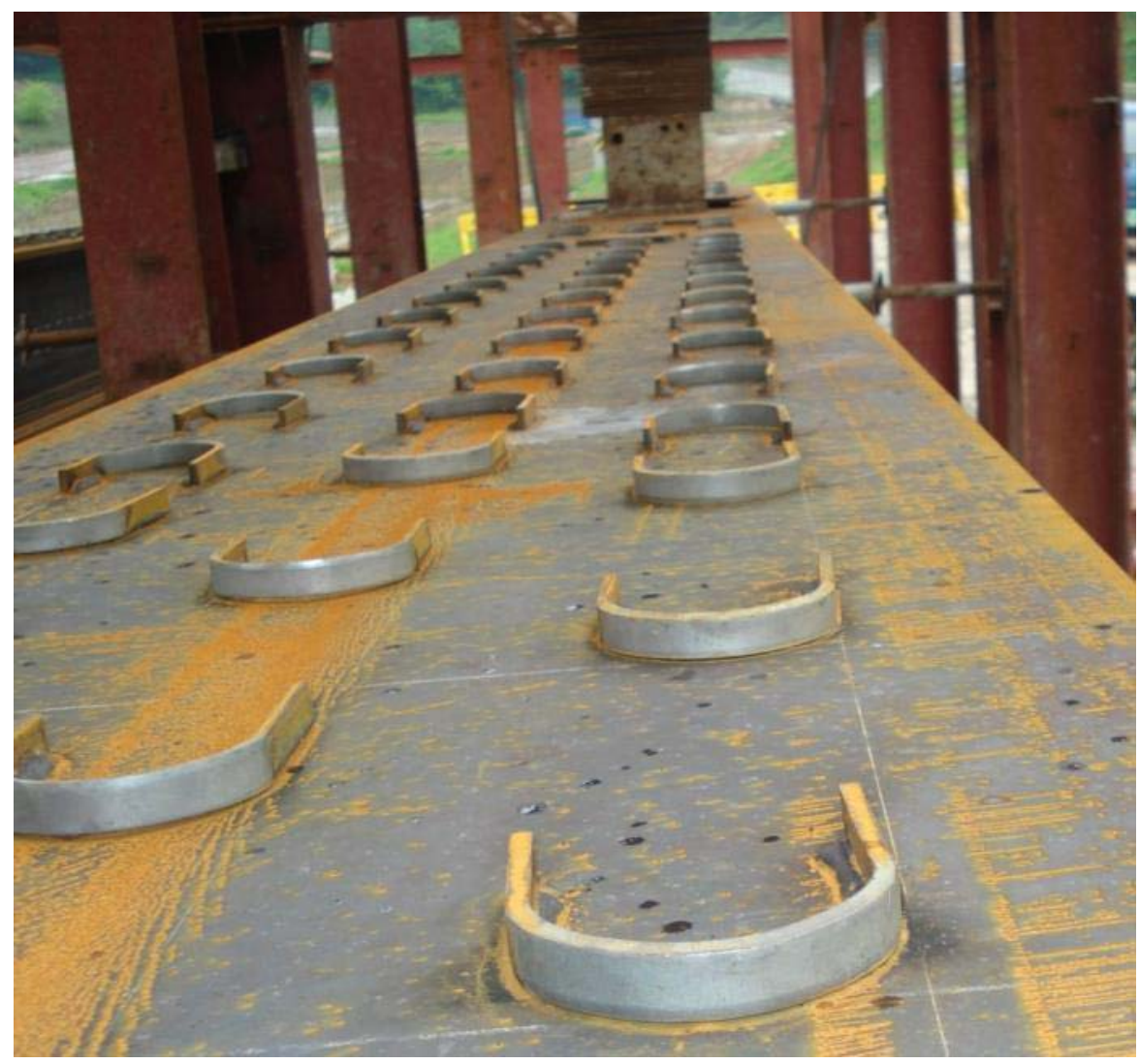

Figure 22. Horseshoe shear connectors installed on the top flange of the preflex beam. 


\section{Load Rating}

\section{Methodology}

Load rating procedures for pre-flex beams were not found in the literature reviewed. The analysis discussed in previous sections is formulated on allowable stress of steel and concrete elements involved in the composite system. To be consistent with the analysis procedures, the load rating methodology applied in this report is based on the general Equation 19.

$$
\mathrm{RF}=\frac{\mathrm{C}-\left(\mathrm{A}_{1}\right)(\mathrm{D})}{\left(\mathrm{A}_{2}\right) \mathrm{L}(1+\mathrm{I})}
$$

where:

$$
\begin{aligned}
\mathrm{RF}= & \text { rating factor } \\
\mathrm{C}= & \text { capacity of the member } \\
\mathrm{A}_{1}= & \text { factor for dead loads }=1.0 \text { for both inventory and operating } \\
& \text { levels } \\
\mathrm{A}_{2}= & \text { factor for live load } 1.0 \text { for both inventory and operating levels } \\
\mathrm{D}= & \text { dead load effect on the member } \\
\mathrm{L}= & \text { live load effect on the member } \\
\mathrm{I}= & \text { impact factor to be used with the live load effect }
\end{aligned}
$$

Equation 19 will be applied at both the inventory and operating levels.

The inventory rating results in a load which can safely utilize an existing structure for an indefinite period of time. The operating rating results in the absolute maximum permissible load to which the structure may be subjected for the vehicle type used in the rating.

According to National Bridge Inventory, an HS20 vehicle should be used to compare rating results with the original design calculations. Other typical legal loads considered in this report can be used to determine allowable loading (i.e., bridge posting) when necessary. 


\section{Rating based on steel stress}

\section{Flexure}

\section{A. Capacity}

From paragraph 6.6.2.1 and table 6.6.2.1-1 of AASHTO's Manual for Condition Evaluation of Bridges (AASHTO 1994) the allowable steel stress, $\mathrm{f}_{\mathrm{y}}$, is reduced from $36 \mathrm{ksi}$ to $33 \mathrm{ksi}$ for inventory level. This reduction is in the order of $10 \%$. For design purposes, the steel beam reaches up to $80 \%$ of its allowable load. Based on these two factors, the allowable steel stress for inventory level considering flexural stresses is assumed as:

$$
\mathrm{C}_{\mathrm{fINV}}=0.9 \times 0.8 \times \mathrm{f}_{\mathrm{y}}=0.9 \times 0.8 \times 30,900 \mathrm{~N} / \mathrm{cm}^{2}=22,248 \mathrm{~N} / \mathrm{cm}^{2}
$$

The implementation of engineering judgment is needed to reduce the capacity of the steel beam, if material degradation, section loss, and/ or cracks are observed in field inspections.

A 15\% increase in capacity is limited between the inventory and operating levels. The authors strongly recommend not exceeding a capacity value of $0.83 \mathrm{f}_{\mathrm{y}}$ for evaluation of flexural stresses at the operating level. The engineer shall judge the condition of steel and apply additional reductions to this factor if needed.

$$
\mathrm{C}_{\text {fOPR }}=0.83 \times \mathrm{f}_{\mathrm{y}}=0.83 \times 30,900 \mathrm{~N} / \mathrm{cm}^{2}=25,647 \mathrm{~N} / \mathrm{cm}^{2}
$$

The smaller section modulus between the top ( $\mathrm{Sx}_{\mathrm{ts}}$ ) and bottom (Sxbs) fiber is selected for the stress calculation as the most critical condition. When a composite action is considered (depending on the stage of analysis), the section moduli are related to a transformed steel section.

\section{B. Dead loads}

The dead load stress includes: 
1. $\sigma_{\text {preflex }}=\frac{\mathrm{M}_{\text {Preflex }}}{\mathrm{Sx}_{1}}=\frac{14,372,000 \mathrm{~N}-\mathrm{m}}{64,265 \mathrm{~cm}^{3}}=22,364 \mathrm{~N} / \mathrm{cm}^{2}$

Where: MPreflex is the moment due to pre-flex loads and $\mathrm{Sx}_{1}$ is the section modulus of the steel section, referenced to the extreme bottom steel fiber.

2.

$\sigma_{\text {Release }}=\frac{M_{\text {Release }}}{\mathrm{Sx}_{3}}=\frac{-14,372,000 \mathrm{~N}-\mathrm{m}}{101,191 \mathrm{~cm}^{3}}=-14,203 \mathrm{~N} / \mathrm{cm}^{2}$

where: $M_{\text {Release }}$ is the internal moment after release of pre-flex loads and $\mathrm{Sx}_{3}$ is the section modulus of the steel beam with concrete c1, referenced to the extreme steel bottom fiber.

3. $\sigma_{\text {Selfweight }}=\frac{\mathrm{M}_{\text {Selfweight }}}{\mathrm{Sx}_{3}}=\frac{3,877,614 \mathrm{~N}-\mathrm{m}}{101,191 \mathrm{~cm}^{3}}=3,832 \mathrm{~N} / \mathrm{cm}^{2}$

where: Mselfweight is the flexural moment produced by the weights of the steel beam and concrete $\mathrm{c1}$.

4. $\sigma_{\mathrm{AW}}=\frac{\mathrm{M}_{\mathrm{AW}}}{\mathrm{Sx}_{3}}=\frac{\mathrm{M}_{\text {Diaphragms }}+\mathrm{M}_{\text {slab }}+\mathrm{M}_{\text {conc. web }}}{\mathrm{Sx}_{3}}$

$$
=\frac{(144,433+3,382,460+753,818) \mathrm{N}-\mathrm{m}}{101,191 \mathrm{~cm}^{3}}=4,230 \mathrm{~N} / \mathrm{cm}^{2}
$$

where: $\mathrm{M}_{\mathrm{Aw}}$ is the flexural moment due to additional weight provided by diaphragms, slab (c2), and web concrete cover (c3). At this stage, the concrete slab and concrete surrounding the steel web have not cured.

5. $\quad \sigma_{\mathrm{SDL}}=\frac{\mathrm{M}_{\mathrm{SDL}}}{\mathrm{Sx}_{7}}=\frac{\mathrm{M}_{\text {Parapet }}+\mathrm{M}_{\mathrm{ws}}+\mathrm{M}_{\text {additional }}}{\mathrm{Sx}_{7}}$

$$
=\frac{(991,933+856,033+171,207) \mathrm{N}-\mathrm{m}}{135,654 \mathrm{~cm}^{3}}=1,488 \mathrm{~N} / \mathrm{cm}^{2}
$$

where: $\mathrm{M}_{\mathrm{SDL}}$ is the bending moment produced by the effects of superimposed dead loads provided by parapets, wearing 
surfaces, and other attachments to the bridge (e.g., lighting and posting). $\mathrm{Sx}_{7}$ is the section modulus of the composite beam including steel and concrete at top and bottom flanges. At this stage, the concrete slab and concrete surrounding the steel web have cured.

6. The displacements produced by initial creep and shrinkage effects provide relaxation to the pre-flex system. Three phases were considered in section 6 . The shrinkage effects of Phase 1 are commonly neglected due to restrictions provided by the steel beam. As a first trial, it is acceptable to include creep and shrinkage effects calculated for Phase 2.

$$
\begin{aligned}
& \sigma_{\text {Ci ssi }}=\frac{\sum N_{c}(t)}{A_{s}+A_{c} / n} \pm \frac{\sum M_{c}(t)}{S_{5}} \\
& =\frac{(-2,000,218-2,195,190) \mathrm{N}}{1,397 \mathrm{~cm}^{2}+3,949 \mathrm{~cm}^{2} / 5.542} \pm \frac{(-74,468-86,619) \mathrm{N}-\mathrm{m}}{121,550 \mathrm{~cm}^{3}}=-2,122 \mathrm{~N} / \mathrm{cm}^{2}
\end{aligned}
$$

7. The final creep and shrinkage displacements calculated by superposition in Section 6 contribute to the loading stress of the pre-flex beam:

$$
\begin{aligned}
& \sigma_{\text {Cf } 8 \text { sf }}=\frac{\sum N_{c}(t)}{A_{s}+A_{c} / n} \pm \frac{\sum M_{c}(t)}{S_{x}} \\
& =\frac{(805,883+903,315) \mathrm{N}}{2,109 \mathrm{~cm}^{2}+7,404 \mathrm{~cm}^{2} / 5.542} \pm \frac{(14,397+18,097) \mathrm{N}-\mathrm{m}}{135,654 \mathrm{~cm}^{3}}=520 \mathrm{~N} / \mathrm{cm}^{2}
\end{aligned}
$$

The final dead load and superimposed dead load stress considered for the target bridge are

$$
\begin{aligned}
& \sigma_{\mathrm{D}}=(22,364-14,203+3,832+4,230+1,488-2,122+520) \mathrm{N} / \mathrm{cm}^{2} \\
& =16,110 \mathrm{~N} / \mathrm{cm}^{2}
\end{aligned}
$$

\section{Live loads}

$$
\sigma_{\mathrm{HS} 20+\mathrm{I}}=\frac{\mathrm{M}_{\mathrm{HS} 20+\mathrm{I}}}{\mathrm{Sx}_{7}}=\frac{2,705,000 \mathrm{~N}-\mathrm{m}}{135,654 \mathrm{~cm}^{3}}=1,994 \mathrm{~N} / \mathrm{cm}^{2}
$$




$$
\begin{aligned}
& \sigma_{\text {type } 3+\mathrm{I}}=\frac{\mathrm{M}_{\text {Type } 3+\mathrm{I}}}{\mathrm{Sx}_{7}}=\frac{1,911,000 \mathrm{~N}-\mathrm{m}}{135,654 \mathrm{~cm}^{3}}=1,409 \mathrm{~N} / \mathrm{cm}^{2} \\
& \sigma_{\text {type } 3 \mathrm{~S} 2+\mathrm{I}}=\frac{\mathrm{M}_{\text {Type 3S2+I }}}{\mathrm{Sx}_{7}}=\frac{2,424,000 \mathrm{~N}-\mathrm{m}}{135,654 \mathrm{~cm}^{3}}=1,787 \mathrm{~N} / \mathrm{cm}^{2} \\
& \sigma_{\text {type 3-3+1 }}=\frac{\mathrm{M}_{\text {Type 3-3+I }}}{\mathrm{Sx}_{7}}=\frac{2,496,000 \mathrm{~N}-\mathrm{m}}{135,654 \mathrm{~cm}^{3}}=1,840 \mathrm{~N} / \mathrm{cm}^{2}
\end{aligned}
$$

\section{Rating factors}

Employing Equation 19, the following rating factors are obtained:

\section{Inventory:}

$$
\begin{aligned}
& \mathrm{RF}_{\mathrm{fHS} 2 \mathrm{O}}=\frac{\mathrm{C}_{\mathrm{f}}-\mathrm{A}_{1} \times \sigma_{\mathrm{D}}}{\mathrm{A}_{2} \times \sigma_{\mathrm{L}+\mathrm{I}}}=\frac{22,248-16,110}{1,994}=\underline{\mathbf{3 . 0 8}} \\
& \mathrm{RF}_{\text {f Type } 3}=\frac{\mathrm{C}_{\mathrm{f}}-\mathrm{A}_{1} \times \sigma_{\mathrm{D}}}{\mathrm{A}_{2} \times \sigma_{\mathrm{L}+\mathrm{I}}}=\frac{22,248-16,110}{1,409}=\underline{\mathbf{4 . 3 6}} \\
& \mathrm{RF}_{\mathrm{fType}_{3 \mathrm{~S} 2}}=\frac{\mathrm{C}_{\mathrm{f}}-\mathrm{A}_{1} \times \sigma_{\mathrm{D}}}{\mathrm{A}_{2} \times \sigma_{\mathrm{L}+\mathrm{I}}}=\frac{22,248-16,110}{1,787}=\underline{\mathbf{3 . 4 3}} \\
& \mathrm{RF}_{\text {f Type 3-3 }}=\frac{\mathrm{C}_{\mathrm{f}}-\mathrm{A}_{1} \times \sigma_{\mathrm{D}}}{\mathrm{A}_{2} \times \sigma_{\mathrm{L}+\mathrm{I}}}=\frac{22,248-16,110}{1,840}=\underline{\mathbf{3 . 3 4}}
\end{aligned}
$$

\section{Operating:}

$$
\begin{aligned}
& \mathrm{RF}_{\mathrm{fHS} 20}=\frac{\mathrm{C}_{\mathrm{f}}-\mathrm{A}_{1} \times \sigma_{\mathrm{D}}}{\mathrm{A}_{2} \times \sigma_{\mathrm{L}+\mathrm{I}}}=\frac{25,647-16,110}{1,994}=\underline{\mathbf{4 . 7 8}} \\
& \mathrm{RF}_{\text {f Type } 3}=\frac{\mathrm{C}_{\mathrm{f}}-\mathrm{A}_{1} \times \sigma_{\mathrm{D}}}{\mathrm{A}_{2} \times \sigma_{\mathrm{L}+\mathrm{I}}}=\frac{25,647-16,110}{1,409}=\underline{\mathbf{6 . 7 7}} \\
& \mathrm{RF}_{\text {f Type } 3 \mathrm{~S} 2}=\frac{\mathrm{C}_{\mathrm{f}}-\mathrm{A}_{1} \times \sigma_{\mathrm{D}}}{\mathrm{A}_{2} \times \sigma_{\mathrm{L}+\mathrm{I}}}=\frac{25,647-16,110}{1,787}=\underline{\mathbf{5 . 3 4}}
\end{aligned}
$$




$$
\mathrm{RF}_{\text {f Type } 3-3}=\frac{\mathrm{C}_{\mathrm{f}}-\mathrm{A}_{1} \times \sigma_{\mathrm{D}}}{\mathrm{A}_{2} \times \sigma_{\mathrm{L}+\mathrm{I}}}=\frac{25,647-16,110}{1,840}=\underline{\mathbf{5 . 1 8}}
$$

\section{Shear}

\section{A. Capacity}

The limiting shear stress for the inventory level is defined in paragraph 6.6.2.1 and table 6.6.2.1-1 of the Manual for Condition Evaluation of Bridges, $C_{i n v}=9,600 \mathrm{~N} / \mathrm{cm}^{2}$ (AASHTO 1994). For the operating level, a value of $\mathrm{C}_{\mathrm{opr}}=13,700 \mathrm{~N} / \mathrm{cm}^{2}$ is recommended.

\section{B. Dead loads}

The dead load shear stress is calculated by dividing the maximum shear loads by the shear-plane area of the steel web obtained as:

$$
A_{\text {web }}=t_{\text {web }} \times h_{\text {web }}=1.8 \mathrm{~cm} \times 99.2 \mathrm{~cm}=178.6 \mathrm{~cm}^{2}
$$

The shear loads induced at $\mathrm{L} / 4$ for pre-flexion are removed during the release stage. For design purposes the shear resistance of the steel web shall be checked, but for load rating calculations these loads are neglected because permanent shear deformations are not expected. Therefore, the dead and superimposed dead load shears and stresses produced by distributed loads along the pre-flex beam are computed with Equations 20 and 21, respectively:

$$
\begin{gathered}
\mathrm{V}=\mathrm{w} \times \frac{\mathrm{L}}{2} \\
\tau=\frac{\sum \mathrm{V}}{\mathrm{A}_{\text {web }}} \\
\tau_{\mathrm{D}}=\frac{\mathrm{V}_{\text {Selfweight }}+\mathrm{V}_{\text {Diaphragm }}+\mathrm{V}_{\text {Slab }}+\mathrm{V}_{\text {ws }}+\mathrm{V}_{\text {Web conc }}+\mathrm{V}_{\text {barrier }}+\mathrm{V}_{\mathrm{AW}}}{\mathrm{A}_{\text {web }}} \\
=\frac{(393,666+14,663+343,397+76,53 \mathrm{O}+100,704+86,907+17,381) \mathrm{N}}{178.6 \mathrm{~cm}^{2}} \\
\tau_{\mathrm{D}}=5,787 \mathrm{~N} / \mathrm{cm}^{2}
\end{gathered}
$$




\section{Live loads}

$$
\begin{aligned}
& \tau_{\text {HS20+I }}=\frac{V_{\text {HS2O+I }}}{A_{\text {web }}}=\frac{338,100 \mathrm{~N}}{178.6 \mathrm{~cm}^{2}}=1,893 \mathrm{~N} / \mathrm{cm}^{2} \\
& \tau_{\text {Type 3+I }}=\frac{V_{\text {Type } 3+\mathrm{I}}}{A_{\text {web }}}=\frac{234,700 \mathrm{~N}}{178.6 \mathrm{~cm}^{2}}=1,314 \mathrm{~N} / \mathrm{cm}^{2} \\
& \tau_{\text {Type 3S2+I }}=\frac{V_{\text {Type 3S2+I }}}{A_{\text {web }}}=\frac{306,900 \mathrm{~N}}{178.6 \mathrm{~cm}^{2}}=1,719 \mathrm{~N} / \mathrm{cm}^{2} \\
& \tau_{\text {Type 3-3+I }}=\frac{V_{\text {Type 3-3+I }}}{A_{\text {web }}}=\frac{322,300 \mathrm{~N}}{178.6 \mathrm{~cm}^{2}}=1,805 \mathrm{~N} / \mathrm{cm}^{2}
\end{aligned}
$$

\section{Rating factors}

Employing Equation 19:

\section{Inventory:}

$$
\begin{aligned}
& \mathrm{RF}_{\mathrm{S} \mathrm{HS}_{20}}=\frac{\mathrm{C}_{\mathrm{s}}-\mathrm{A}_{1} \times \tau_{\mathrm{D}}}{\mathrm{A}_{2} \times \tau_{\mathrm{L}+\mathrm{I}}}=\frac{9,600-5,787}{1,893}=\underline{\mathbf{2 . 0 1}} \\
& \mathrm{RF}_{\text {s Type } 3}=\frac{\mathrm{C}_{\mathrm{s}}-\mathrm{A}_{1} \times \tau_{\mathrm{D}}}{\mathrm{A}_{2} \times \tau_{\mathrm{L}+\mathrm{I}}}=\frac{9,600-5,787}{1,314}=\underline{\mathbf{2 . 9 0}} \\
& \mathrm{RF}_{\text {S Type } 3 \mathrm{~S} 2}=\frac{\mathrm{C}_{\mathrm{s}}-\mathrm{A}_{1} \times \tau_{\mathrm{D}}}{\mathrm{A}_{2} \times \tau_{\mathrm{L}+\mathrm{I}}}=\frac{9,600-5,787}{1,719}=\underline{\mathbf{2 . 2 2}} \\
& \mathrm{RF}_{\text {s Type } 3-3}=\frac{\mathrm{C}_{\mathrm{s}}-\mathrm{A}_{1} \times \tau_{\mathrm{D}}}{\mathrm{A}_{2} \times \tau_{\mathrm{L}+\mathrm{I}}}=\frac{9,600-5,787}{1,805}=\underline{\mathbf{2 . 1 1}}
\end{aligned}
$$

\section{Operating:}

$$
\begin{aligned}
& \mathrm{RF}_{\mathrm{s} \mathrm{HS}_{20}}=\frac{\mathrm{C}_{\mathrm{s}}-\mathrm{A}_{1} \times \tau_{\mathrm{D}}}{\mathrm{A}_{2} \times \tau_{\mathrm{L}+\mathrm{I}}}=\frac{13,700-5,787}{1,893}=\underline{\mathbf{4 . 1 8}} \\
& \mathrm{RF}_{\text {s Type } 3}=\frac{\mathrm{C}_{\mathrm{s}}-\mathrm{A}_{1} \times \tau_{\mathrm{D}}}{\mathrm{A}_{2} \times \tau_{\mathrm{L}+\mathrm{I}}}=\frac{13,700-5,787}{1,314}=\underline{\mathbf{6 . 0 2}}
\end{aligned}
$$




$$
\begin{aligned}
& \mathrm{RF}_{\text {s Type } 3 \mathrm{~S} 2_{2}}=\frac{\mathrm{C}_{\mathrm{s}}-\mathrm{A}_{1} \times \tau_{\mathrm{D}}}{\mathrm{A}_{2} \times \tau_{\mathrm{L}+\mathrm{I}}}=\frac{13,700-5,787}{1,719}=\underline{\mathbf{4 . 6 0}} \\
& \mathrm{RF}_{\text {s Type } 3-3}=\frac{\mathrm{C}_{\mathrm{s}}-\mathrm{A}_{1} \times \tau_{\mathrm{D}}}{\mathrm{A}_{2} \times \tau_{\mathrm{L}+\mathrm{I}}}=\frac{13,700-5,787}{1,805}=\underline{\mathbf{4 . 3 8}}
\end{aligned}
$$

\section{Rating based on concrete stress at top flange (slab)}

\section{Flexure}

\section{A. Capacity}

From article 6.6.2.4 of the Manual for condition evaluation of bridges (AASHTO), the maximum allowable stresses for concrete at inventory and operating levels are $\mathrm{C}_{\mathrm{inv}}=1,100 \mathrm{~N} / \mathrm{cm}^{2}(1,600 \mathrm{psi})$ and $\mathrm{C}_{\mathrm{opr}}=1,65 \mathrm{ON} / \mathrm{cm}^{2}(2,400 \mathrm{psi})$ for slab concrete with a compressive strength, $\mathrm{f}_{\mathrm{C}}^{\prime}=4,000 \mathrm{psi}\left(2,750 \mathrm{~N} / \mathrm{cm}^{2}\right)$.

\section{B. Dead loads}

The section modulus used for the stress calculations is related to top concrete extreme fiber assuming composite action and a transformed concrete section. The pre-flex, release, and selfweight loads are acting on the composite pre-flex beam prior to the hardening of slab concrete. Therefore, the loads considered are those related to superimposed dead loads:

$$
\begin{aligned}
& \sigma_{\mathrm{SDL}}=\frac{\mathrm{M}_{\mathrm{SDL}}}{\mathrm{Sx}_{12}}=\frac{\mathrm{M}_{\text {Parapet }}+\mathrm{M}_{\mathrm{ws}}+\mathrm{M}_{\text {additional }}}{\mathrm{Sx}_{12}} \\
& =\frac{(-991,933-856,033-171,207) \mathrm{N}-\mathrm{m}}{864,920 \mathrm{~cm}^{3}}=-233^{\mathrm{N}} / \mathrm{cm}^{2}
\end{aligned}
$$

In addition, the creep and shrinkage effects considered at this stage are:

$$
\begin{aligned}
& \sigma_{\mathrm{Cf} \& \mathrm{Sf}}=\frac{\sum \mathrm{N}_{\mathrm{c}}(\mathrm{t})}{\mathrm{A}_{\mathrm{c}}+\mathrm{A}_{\mathrm{s}} \times \mathrm{n}} \pm \frac{\sum \mathrm{M}_{\mathrm{c}}(\mathrm{t})}{\mathrm{Sx}_{12}} \\
& =\frac{(-805,883-903,315) \mathrm{N}}{7,404 \mathrm{~cm}^{2}+2,109 \mathrm{~cm}^{2} \times 5.542} \pm \frac{(-14,397-18,097) \mathrm{N}-\mathrm{m}}{864,920 \mathrm{~cm}^{3}}=-93 \mathrm{~N} / \mathrm{cm}^{2}
\end{aligned}
$$


The total dead load effects considered are:

$$
\sigma_{\mathrm{D}}=(-233-93)^{\mathrm{N}} / \mathrm{cm}^{2}=-326 \mathrm{~N} / \mathrm{cm}^{2}
$$

\section{Live loads}

$$
\begin{aligned}
& \sigma_{\mathrm{HS} 20+\mathrm{I}}=\frac{\mathrm{M}_{\mathrm{HS} 20+\mathrm{I}}}{\mathrm{Sx}_{12}}=\frac{2,705,000 \mathrm{~N}-\mathrm{m}}{864,920 \mathrm{~cm}^{3}}=313 \mathrm{~N} / \mathrm{cm}^{2} \\
& \sigma_{\text {Type } 3+\mathrm{I}}=\frac{\mathrm{M}_{\text {Type } 3+\mathrm{I}}}{\mathrm{Sx}_{12}}=\frac{1,911,000 \mathrm{~N}-\mathrm{m}}{864,920 \mathrm{~cm}^{3}}=221 \mathrm{~N} / \mathrm{cm}^{2} \\
& \sigma_{\text {Type 3S2+I }}=\frac{\mathrm{M}_{\text {Type 3S2+I }}}{\mathrm{Sx}_{12}}=\frac{2,424,000 \mathrm{~N}-\mathrm{m}}{864,920 \mathrm{~cm}^{3}}=280 \mathrm{~N} / \mathrm{cm}^{2} \\
& \sigma_{\text {Type 3-3+1 }}=\frac{\mathrm{M}_{\text {Type 3-3+I I }}}{\mathrm{Sx}_{12}}=\frac{2,496,000 \mathrm{~N}^{2} \mathrm{~m}}{864,920 \mathrm{~cm}^{3}}=289 \mathrm{~N} / \mathrm{cm}^{2}
\end{aligned}
$$

\section{Rating factors}

\section{Inventory:}

$$
\begin{aligned}
& \mathrm{RF}_{\mathrm{fHS} 2 \mathrm{O}}=\frac{\mathrm{C}_{\mathrm{f}}-\mathrm{A}_{1} \times \sigma_{\mathrm{D}}}{\mathrm{A}_{2} \times \sigma_{\mathrm{L}+\mathrm{I}}}=\frac{1,100-326}{313}=\underline{\mathbf{2 . 4 7}} \\
& \mathrm{RF}_{\mathrm{ftype}_{3}}=\frac{\mathrm{C}_{\mathrm{f}}-\mathrm{A}_{1} \times \sigma_{\mathrm{D}}}{\mathrm{A}_{2} \times \sigma_{\mathrm{L}+\mathrm{I}}}=\frac{1,100-326}{221}=\underline{\mathbf{3 . 5 0}} \\
& \mathrm{RF}_{\text {ftype } 3 \mathrm{~S} 2}=\frac{\mathrm{C}_{\mathrm{f}}-\mathrm{A}_{1} \times \sigma_{\mathrm{D}}}{\mathrm{A}_{2} \times \sigma_{\mathrm{L}+\mathrm{I}}}=\frac{1,100-326}{280}=\underline{\mathbf{2 . 7 6}} \\
& \mathrm{RF}_{\mathrm{ftype} 3-3}=\frac{\mathrm{C}_{\mathrm{f}}-\mathrm{A}_{1} \times \sigma_{\mathrm{D}}}{\mathrm{A}_{2} \times \sigma_{\mathrm{L}+\mathrm{I}}}=\frac{1,100-326}{289}=\underline{\mathbf{2 . 6 8}}
\end{aligned}
$$

\section{Operating:}

$$
\mathrm{RF}_{\mathrm{fHS} 2 \mathrm{O}}=\frac{\mathrm{C}_{\mathrm{f}}-\mathrm{A}_{1} \times \sigma_{\mathrm{D}}}{\mathrm{A}_{2} \times \sigma_{\mathrm{L}+\mathrm{I}}}=\frac{1,650-326}{313}=\underline{\mathbf{4 . 2 3}}
$$




$$
\begin{aligned}
& \mathrm{RF}_{\text {ftype } 3}=\frac{\mathrm{C}_{\mathrm{f}}-\mathrm{A}_{1} \times \sigma_{\mathrm{D}}}{\mathrm{A}_{2} \times \sigma_{\mathrm{L}+\mathrm{I}}}=\frac{1,650-326}{221}=\underline{\mathbf{5 . 9 9}} \\
& \mathrm{RF}_{\text {ftype } 3 \mathrm{~S} 2}=\frac{\mathrm{C}_{\mathrm{f}}-\mathrm{A}_{1} \times \sigma_{\mathrm{D}}}{\mathrm{A}_{2} \times \sigma_{\mathrm{L}+\mathrm{I}}}=\frac{1,650-326}{280}=\underline{\mathbf{4 . 7 2}} \\
& \mathrm{RF}_{\text {ftype } 3-3}=\frac{\mathrm{C}_{\mathrm{f}}-\mathrm{A}_{1} \times \sigma_{\mathrm{D}}}{\mathrm{A}_{2} \times \sigma_{\mathrm{L}+\mathrm{I}}}=\frac{1,650-326}{289}=\underline{\mathbf{4 . 5 9}}
\end{aligned}
$$

\section{Rating based on concrete stress at bottom flange}

\section{Flexure}

\section{A. Capacity}

From article 6.6.2.4 of the Manual for Condition Evaluation of Bridges, for $\mathrm{f}_{\mathrm{C}}^{\prime}=5,000 \mathrm{psi}\left(3,440 \mathrm{~N} / \mathrm{cm}^{2}\right)$ or greater, $\mathrm{C}_{\mathrm{inv}}=$ $1,370 \mathrm{~N} / \mathrm{cm}^{2}$ and $\mathrm{C}_{\mathrm{opr}}=2,060 \mathrm{~N} / \mathrm{cm}^{2}$ (AASHTO 2002).

\section{B. Dead loads}

The section modulus used for the stress calculations is referenced to the bottom concrete extreme fiber assuming composite action. For the stress calculation, all loads considered are applied, except the pre-flexion, because c 1 concrete is not present at this stage. The stresses are

1.

$$
\sigma_{\text {Release }}=\frac{M_{\text {Release }}}{\mathrm{Sx}_{9}}=\frac{14,372,000 \mathrm{~N}-\mathrm{m}}{701,189 \mathrm{~cm}^{3}}=-2,050 \mathrm{~N} / \mathrm{cm}^{2}
$$

where: $M_{\text {Release }}$ is the internal moment after release of pre-flex loads and Sxg is the section modulus referenced to the concrete extreme bottom fiber with composite action.

2. $\sigma_{\text {Selfweight }}=\frac{\mathrm{M}_{\text {Selfweight }}}{\mathrm{Sx}_{9}}=\frac{3,877,614 \mathrm{~N}-\mathrm{m}}{701,189 \mathrm{~cm}^{3}}=553 \mathrm{~N} / \mathrm{cm}^{2}$

where: MSelfweight is the flexural moment produced by the weights of the steel beam and the bottom concrete block. 
3. $\sigma_{\mathrm{AW}}=\frac{\mathrm{M}_{\mathrm{AW}}}{\mathrm{Sx}_{9}}=\frac{\mathrm{M}_{\text {Diaphragms }}+\mathrm{M}_{\text {slab }}+\mathrm{M}_{\text {conc. web }}}{\mathrm{S}_{\mathrm{x} 9}}$

$$
=\frac{(144,433+3,382,460+753,818) \mathrm{N}-\mathrm{m}}{701,189 \mathrm{~cm}^{3}}=610 \mathrm{~N} / \mathrm{cm}^{2}
$$

where: $\mathrm{M}_{\mathrm{AW}}$ is the flexural moment due to additional weight provided by diaphragms, slab (c2), and web concrete cover (c3). Sxy is the section modulus of the composite beam, including steel and bottom concrete and is referenced to the concrete extreme bottom fiber. At this stage, all concrete surrounding the steel has not fully cured.

4. $\sigma_{\mathrm{SDL}}=\frac{\mathrm{M}_{\mathrm{SDL}}}{\mathrm{Sx}_{11}}=\frac{\mathrm{M}_{\text {Parapet }}+\mathrm{M}_{\mathrm{ws}}+\mathrm{M}_{\text {additional }}}{\mathrm{Sx}_{11}}$

$$
=\frac{(991,933+856,033+171,207) \mathrm{N}-\mathrm{m}}{639,695 \mathrm{~cm}^{3}}=316 \mathrm{~N} / \mathrm{cm}^{2}
$$

where: $\mathrm{M}_{\mathrm{SDL}}$ is the bending moment produced by the effects of superimposed dead loads (parapets, wearing surfaces, and attachments to the bridge). The section modulus is referenced to the concrete extreme bottom fiber, considering composite action provided by the steel beam, the bottom concrete, and the slab.

5. Initial creep and shrinkage (relaxation):

$$
\begin{aligned}
& \sigma_{\mathrm{Ci} \& \mathrm{Si}}=\frac{\sum \mathrm{N}_{\mathrm{c}}(\mathrm{t})}{\mathrm{A}_{\mathrm{c}}+\mathrm{A}_{\mathrm{s}} \times \mathrm{n}} \pm \frac{\sum \mathrm{M}_{\mathrm{c}}(\mathrm{t})}{\mathrm{Sx}_{10}} \\
& =\frac{(-2,000,218-2,195,190) \mathrm{N}}{3,949 \mathrm{~cm}^{2}+1,397 \mathrm{~cm}^{2} \times 5.542} \pm \frac{(-74,468-86,619) \mathrm{N}-\mathrm{m}}{520,335 \mathrm{~cm}^{3}}=-390 \mathrm{~N} / \mathrm{cm}^{2}
\end{aligned}
$$

6. The final creep and shrinkage displacements calculated by superposition in the previous section contribute to the loading stress of the pre-flex beam:

$$
\begin{aligned}
& \sigma_{\text {Cf } \& \mathrm{Sf}}=\frac{\sum \mathrm{N}_{\mathrm{c}}(\mathrm{t})}{\mathrm{A}_{\mathrm{c}}+\mathrm{A}_{\mathrm{s}} \times \mathrm{n}} \pm \frac{\sum \mathrm{M}_{\mathrm{c}}(\mathrm{t})}{\mathrm{Sx}_{11}} \\
& =\frac{(805,883+903,315) \mathrm{N}}{7,404 \mathrm{~cm}^{2}+2,109 \mathrm{~cm}^{2} \times 5.542} \pm \frac{(14,397+18,097) \mathrm{N}-\mathrm{m}}{639,695 \mathrm{~cm}^{3}}=95 \mathrm{~N} / \mathrm{cm}^{2}
\end{aligned}
$$


The final dead and superimposed dead load stress considered for the example bridge are

$$
\sigma_{\mathrm{D}}=(-2,050+553+610+316-390+95) \mathrm{N} / \mathrm{cm}^{2}=-866 \mathrm{~N} / \mathrm{cm}^{2}
$$

\section{Live loads}

$$
\begin{aligned}
& \sigma_{\mathrm{HS} 20+\mathrm{I}_{1}}=\frac{\mathrm{M}_{\mathrm{HS}_{20+1}}}{\mathrm{Sx}_{11}}=\frac{2,705,000 \mathrm{~N}-\mathrm{m}}{639,695 \mathrm{~cm}^{3}}=423 \mathrm{~N} / \mathrm{cm}^{2} \\
& \sigma_{\text {Type } 3+\mathrm{I}}=\frac{\mathrm{M}_{\text {Type } 3+\mathrm{I}}}{\mathrm{Sx}_{11}}=\frac{1,911,000 \mathrm{~N}-\mathrm{m}}{639,695 \mathrm{~cm}^{3}}=299 \mathrm{~N} / \mathrm{cm}^{2} \\
& \sigma_{\text {Type } 3 \mathrm{~S} 2+\mathrm{I}}=\frac{\mathrm{M}_{\text {Type } 3 \mathrm{~S} 2+\mathrm{I}}}{\mathrm{Sx}_{11}}=\frac{2,424,000 \mathrm{~N}-\mathrm{m}}{639,695 \mathrm{~cm}^{3}}=379 \mathrm{~N} / \mathrm{cm}^{2} \\
& \sigma_{\text {Type } 3-3+\mathrm{I}}=\frac{\mathrm{M}_{\text {Type } 3-3+\mathrm{I}}}{\mathrm{Sx}_{11}}=\frac{2,496,000 \mathrm{~N}-\mathrm{m}}{639,695 \mathrm{~cm}^{3}}=390 \mathrm{~N} / \mathrm{cm}^{2}
\end{aligned}
$$

\section{Rating factors}

\section{Inventory:}

$$
\begin{aligned}
& \mathrm{RF}_{\mathrm{fHS} 2 \mathrm{O}}=\frac{\mathrm{C}_{\mathrm{f}}-\mathrm{A}_{1} \times \sigma_{\mathrm{D}}}{\mathrm{A}_{2} \times \sigma_{\mathrm{L}+\mathrm{I}}}=\frac{1,37 \mathrm{O}-866}{423}=\underline{\mathbf{1 . 1 9}} \\
& \mathrm{RF}_{\text {ftype } 3}=\frac{\mathrm{C}_{\mathrm{f}}-\mathrm{A}_{1} \times \sigma_{\mathrm{D}}}{\mathrm{A}_{2} \times \sigma_{\mathrm{L}+\mathrm{I}}}=\frac{1,370-866}{299}=\underline{\mathbf{1 . 6 9}} \\
& \mathrm{RF}_{\text {ftype } 3 \mathrm{~S} 2}=\frac{\mathrm{C}_{\mathrm{f}}-\mathrm{A}_{1} \times \sigma_{\mathrm{D}}}{\mathrm{A}_{2} \times \sigma_{\mathrm{L}+\mathrm{I}}}=\frac{1,370-866}{379}=\underline{\mathbf{1 . 3 3}} \\
& \mathrm{RF}_{\text {ftype } 3-3}=\frac{\mathrm{C}_{\mathrm{f}}-\mathrm{A}_{1} \times \sigma_{\mathrm{D}}}{\mathrm{A}_{2} \times \sigma_{\mathrm{L}+\mathrm{I}}}=\frac{1,370-866}{390}=\underline{\mathbf{1 . 2 9}}
\end{aligned}
$$

\section{Operating:}

$$
\mathrm{RF}_{\mathrm{fHS} 2 \mathrm{O}}=\frac{\mathrm{C}_{\mathrm{f}}-\mathrm{A}_{1} \times \sigma_{\mathrm{D}}}{\mathrm{A}_{2} \times \sigma_{\mathrm{L}+\mathrm{I}}}=\frac{2,060-866}{423}=\underline{\mathbf{2 . 8 2}}
$$




$$
\begin{aligned}
& \mathrm{RF}_{\text {ftype } 3}=\frac{\mathrm{C}_{\mathrm{f}}-\mathrm{A}_{1} \times \sigma_{\mathrm{D}}}{\mathrm{A}_{2} \times \sigma_{\mathrm{L}+\mathrm{I}}}=\frac{2,060-866}{299}=\underline{\mathbf{4 . 0 0}} \\
& \mathrm{RF}_{\text {ftype } 3 \mathrm{~S} 2}=\frac{\mathrm{C}_{\mathrm{f}}-\mathrm{A}_{1} \times \sigma_{\mathrm{D}}}{\mathrm{A}_{2} \times \sigma_{\mathrm{L}+\mathrm{I}}}=\frac{2,060-866}{379}=\underline{\mathbf{3 . 1 5}} \\
& \mathrm{RF}_{\text {ftype 3-3}}=\frac{\mathrm{C}_{\mathrm{f}}-\mathrm{A}_{1} \times \sigma_{\mathrm{D}}}{\mathrm{A}_{2} \times \sigma_{\mathrm{L}+\mathrm{I}}}=\frac{2,060-866}{390}=\underline{\mathbf{3 . 0 6}}
\end{aligned}
$$

All load ratings are summarized in Table 9. The rating is controlled by bottom concrete (c1) stresses.

Table 9. Summary of load rating factors based on ASR method.

\begin{tabular}{|l|l|l|l|l|l|l|l|l|}
\hline \multirow{2}{*}{ Vehicle } & \multicolumn{9}{|c|}{ Rating Factors } \\
\cline { 2 - 9 } & \multicolumn{1}{|c|}{ Flexural steel stress } & \multicolumn{2}{|c|}{ Shear stress } & \multicolumn{2}{|c|}{ Top concrete stress } & \multicolumn{2}{c|}{ Bottom concrete stress } \\
\cline { 2 - 9 } & Inventory & Operating & Inventory & Operating & Inventory & Operating & Inventory & Operating \\
\hline HS-20 & 3.08 & 4.78 & 2.01 & 4.18 & 2.47 & 4.23 & 1.19 & 2.82 \\
\hline Type 3 & 4.36 & 6.77 & 2.90 & 6.02 & 3.50 & 5.99 & 1.69 & 4.00 \\
\hline Type 3S2 & 3.43 & 5.34 & 2.22 & 4.60 & 2.76 & 4.72 & 1.33 & 3.15 \\
\hline Type 3-3 & 3.34 & 5.18 & 2.11 & 4.38 & 2.68 & 4.59 & 1.29 & 3.06 \\
\hline
\end{tabular}




\section{Military Load Classification (MLC)}

\section{Brief description of the analysis}

Table 9 (Chapter 8) shows the civilian load ratings associated with flexural and shear loads based on the Allowable Stress Method. The controlling region (bottom concrete, c1) will be used to obtain the appropriate MLC, in accordance with the U.S. Army Military Nonstandard Fixed Bridging Field Manual (FM) 3-34.343 (Headquarters, Department of the Army 2001.)

Once rating factors for civilian truck loadings are determined, Equation 19 may be used to obtain an adequate MLC. Setting the rating equation equal to one and using a less conservative impact effect of 0.15 , an allowable live loading can be obtained as illustrated below:

$$
\begin{aligned}
& \mathrm{RF}=\frac{\mathrm{C}_{\mathrm{f}}-\left(\mathrm{A}_{1}\right)\left(\sigma_{\mathrm{D}}\right)}{\left(\mathrm{A}_{2}\right) \sigma_{\mathrm{L}+\mathrm{I}}}=1.0 \\
& \sigma_{\mathrm{LL}-\mathrm{INV}}=\frac{\mathrm{C}_{\mathrm{f}}-\left(\mathrm{A}_{1}\right)\left(\sigma_{\mathrm{D}}\right)}{\left(\mathrm{A}_{2}\right)(\mathrm{DF})(1+0.15)}=\frac{(1,370-866) \mathrm{N} / \mathrm{cm}^{2}}{1.6109 \times(1+0.15)}=272 \mathrm{~N} / \mathrm{cm}^{2} \\
& \sigma_{\mathrm{LL}-\mathrm{OPR}}=\frac{\mathrm{C}_{\mathrm{f}}-\left(\mathrm{A}_{1}\right)\left(\sigma_{\mathrm{D}}\right)}{\left(\mathrm{A}_{2}\right)(\mathrm{DF})(1+0.15)}=\frac{(2,060-866) \mathrm{N} / \mathrm{cm}^{2}}{1.6109 \times(1+0.15)}=645 \mathrm{~N} / \mathrm{cm}^{2}
\end{aligned}
$$

The distribution factors (DF) are not a function of the type of vehicle. Therefore, the same DF computed in Chapter 4 were used in Equation 19.

After the allowable stresses at the inventory and operating levels are established, the allowable moments are determined next:

$$
\begin{aligned}
& \mathrm{M}_{\mathrm{LL}-\mathrm{INV}}=\sigma_{\mathrm{LL}-\mathrm{INV}} \times \mathrm{Sx}_{11}=272 \mathrm{~N} / \mathrm{cm}^{2} \times 639,695 \mathrm{~cm}^{3}=1,741 \mathrm{kN}-\mathrm{m}=1,284 \mathrm{k}-\mathrm{ft} \\
& \mathrm{M}_{\mathrm{LL}-\mathrm{OPR}}=\sigma_{\mathrm{LL}-\mathrm{OPR}} \times \mathrm{Sx}_{11}=645 \mathrm{~N} / \mathrm{cm}^{2} \times 639,695 \mathrm{~cm}^{3}=4,124 \mathrm{kN}-\mathrm{m}=3,041 \mathrm{k}-\mathrm{ft}
\end{aligned}
$$

Note that the live load moments previously obtained are equivalent to a vehicular line (wheel) load. This live load must be converted to an axle live load effect (by multiplying by 2.0) in order to use the tabulated values listed in Figures 39 and 40 of Field Manual 3-34.343. 


$$
\begin{aligned}
& M_{\text {L-INV }}=2 \times 1,284 \mathrm{k}-\mathrm{ft}=2,568 \mathrm{k}-\mathrm{ft} \\
& M_{\text {L-OPR }}=2 \times 3,041 \mathrm{k}-\mathrm{ft}=6,083 \mathrm{k}-\mathrm{ft}
\end{aligned}
$$

\section{Two-lane loading}

The wheeled (W) and tracked (T) MLC live load effects that approximate these axle loadings and the proper interpolations are shown in Tables 10 and 11. The highlighted fields are the values that were obtained by linear interpolation.

\begin{tabular}{|c|c|c|c|c|c|}
\hline \multicolumn{5}{|c|}{ Two-lane inventory } & \\
\hline Span (ft) & $30 \mathrm{~W}(\mathrm{k}-\mathrm{ft})$ & $40 W(k-f t)$ & $40 \mathrm{~T}(\mathrm{k}-\mathrm{ft})$ & $50 \mathrm{~T}(\mathrm{k}-\mathrm{ft})$ & \\
\hline 120 & 1,841 & 2,010 & 2,280 & 2,840 & \\
\hline 129.3 & 2,387 & 2,622 & 2,465 & 3,072 & \\
\hline 130 & 2,430 & 2,670 & 2,480 & 3,090 & \\
\hline \multicolumn{6}{|c|}{$129.3 \mathrm{ft} \mathrm{span}$} \\
\hline $30 W(k-f t)$ & 2,387 & 30 & $40 \mathrm{~T}(\mathrm{k}-\mathrm{ft})$ & 2,465 & 40 \\
\hline$x$ & 2,568 & 38 & $x$ & 2,568 & 42 \\
\hline $40 \mathrm{~W}(\mathrm{k}-\mathrm{ft})$ & 2,622 & 40 & $50 \mathrm{~T}(\mathrm{k}-\mathrm{ft})$ & 3,072 & 50 \\
\hline
\end{tabular}

Table 10. Military Load Class live load effects - Inventory two-lane.

\begin{tabular}{|c|c|c|c|c|c|}
\hline \multicolumn{5}{|c|}{ Two-lane operating } & \\
\hline Span (ft) & $100 \mathrm{~W}(\mathrm{k}-\mathrm{ft})$ & $120 \mathrm{~W}(\mathrm{k}-\mathrm{ft})$ & $100 \mathrm{~T}(\mathrm{k}-\mathrm{ft})$ & $120 \mathrm{~T}(\mathrm{k}-\mathrm{ft})$ & \\
\hline 120 & 5,560 & 6,670 & 5,550 & 6,670 & \\
\hline 129.3 & 6,088 & 7,310 & 6,014 & 7,310 & \\
\hline 130 & 6,130 & 7,360 & 6,050 & 7,360 & \\
\hline \multicolumn{6}{|c|}{$\underline{129.3 \mathrm{ft} \mathrm{span}}$} \\
\hline $100 \mathrm{~W}(\mathrm{k}-\mathrm{ft})$ & 6,088 & 100 & $100 \mathrm{~T}(\mathrm{k}-\mathrm{ft})$ & 6,014 & 100 \\
\hline$x$ & 6,083 & 100 & $x$ & 6,083 & 101 \\
\hline $120 \mathrm{~W}(\mathrm{k}-\mathrm{ft})$ & 7,310 & 120 & $120 \mathrm{~T}(\mathrm{k}-\mathrm{ft})$ & 7,310 & 120 \\
\hline
\end{tabular}

Table 11. Military Load Class live load effects - Operating two-lane.

The recommended two-lane MLC for this structure is 38 Wheeled / 42 Tracked (inventory) and 100 Wheeled / 101 Tracked (operating). 


\section{One-lane loading}

To determine the MLC for one-lane loading, Table 3-1 of the FM 334.343343 (Headquarters, Department of the Army 2001.) lists conversion factors for various structure configurations. For a concrete deck supported by multi-I-beam girders, the conversion factor is 1.27. The previously computed axle live load moments should be multiplied by this conversion factor to determine the appropriate one-lane loading MLC.

$$
\begin{aligned}
& \mathrm{M}_{\mathrm{LL}-\mathrm{INV}}=1.27 \times 2,568 \mathrm{k}-\mathrm{ft}=3,262 \mathrm{k}-\mathrm{ft} \\
& \mathrm{M}_{\mathrm{LL}-\mathrm{OPR}}=1.27 \times 6,083 \mathrm{k}-\mathrm{ft}=7,725 \mathrm{k}-\mathrm{ft}
\end{aligned}
$$

The MLC live load effects that approximate these axle loadings and the proper interpolations are shown in Tables 12 and 13.

\begin{tabular}{|c|c|c|c|c|c|}
\hline \multicolumn{5}{|c|}{ One-lane inventory } & \\
\hline Span (ft) & $50 \mathrm{~W}(\mathrm{k}-\mathrm{ft})$ & $60 \mathrm{~W}(\mathrm{k}-\mathrm{ft})$ & $50 \mathrm{~T}(\mathrm{k}-\mathrm{ft})$ & $60 \mathrm{~T}(\mathrm{k}-\mathrm{ft})$ & \\
\hline 120 & 2,970 & 3,540 & 2,840 & 3,390 & \\
\hline 129.3 & 3,239 & 3,855 & 3,072 & 3,668 & \\
\hline 130 & 3,260 & 3,880 & 3,090 & 3,690 & \\
\hline \multicolumn{6}{|c|}{$129.3 \mathrm{ft}$ span } \\
\hline $50 \mathrm{~W}(\mathrm{k}-\mathrm{ft})$ & 3,239 & 50 & $50 \mathrm{~T}(\mathrm{k}-\mathrm{ft})$ & 3,090 & 50 \\
\hline$x$ & 3,262 & 50 & $x$ & 3,262 & 53 \\
\hline $60 \mathrm{~W}(\mathrm{k}-\mathrm{ft})$ & 3,855 & 60 & $60 \mathrm{~T}(\mathrm{k}-\mathrm{ft})$ & 3,668 & 60 \\
\hline
\end{tabular}

Table 12. Military Load Class live load effects - Inventory one-lane.

\begin{tabular}{|c|c|c|c|c|c|}
\hline \multicolumn{5}{|c|}{ One-lane operating } & \\
\hline Span (ft) & $120 \mathrm{~W}(\mathrm{k}-\mathrm{ft})$ & $150 \mathrm{~W}(\mathrm{k}-\mathrm{ft})$ & $120 \mathrm{~T}(\mathrm{k}-\mathrm{ft})$ & $150 \mathrm{~T}(\mathrm{k}-\mathrm{ft})$ & \\
\hline 120 & 6,670 & 7,910 & 6,600 & 8,100 & \\
\hline 129.3 & 7,310 & 8,698 & 7,156 & 8,795 & \\
\hline 130 & 7,360 & 8,760 & 7,200 & 8,850 & \\
\hline \multicolumn{6}{|c|}{$129.3 \mathrm{ft} \mathrm{span}$} \\
\hline $120 \mathrm{~W}(\mathrm{k}-\mathrm{ft})$ & 7,310 & 120 & $120 \mathrm{~T}(\mathrm{k}-\mathrm{ft})$ & 7,146 & 120 \\
\hline$x$ & 7,725 & 129 & $x$ & 7,725 & 130 \\
\hline $150 \mathrm{~W}(\mathrm{k}-\mathrm{ft})$ & 8,698 & 150 & $150 \mathrm{~T}(\mathrm{k}-\mathrm{ft})$ & 8,795 & 150 \\
\hline
\end{tabular}

Table 13. Military Load Class live load effects - Operating one-lane. 
The recommended one-lane MLC for this structure is 50 Wheeled/ 53 Tracked (inventory) and 129 Wheeled / 130 Tracked (operating).

Note that the two-lane to one-lane conversion factor (1.27) allowed the recommendation of heavier tracked and wheeled vehicles.

Table 14 and Figure 23 present the recommended MLC values previously obtained.

\section{Roadway width classification and restrictions}

Table 3-4 of the FM 3-34.343 lists the minimum curb-to-curb width requirements to accommodate one-lane and two-lane configurations. Structures designated as two-lane bridges must meet the two-lane width requirements listed in Table 3-4. The two-lane MLC classification should be downgraded if the aforementioned requirements are not met.

The example structure considered offers more than 32-ft of roadway (see Figure 5) and should be able to accommodate all standard military vehicles (one-lane or two-lane) bearing the same or lower MLC classification.

Table 14. Recommended MLC for target pre-flex bridge.

\begin{tabular}{|l|l|l|l|l|l|l|l|l|}
\hline \multirow{4}{*}{ Vehicle } & \multicolumn{3}{|c|}{ Inventory Flexure } & \multicolumn{3}{c|}{ Operating Flexure } \\
\cline { 2 - 9 } & Wheeled & \multicolumn{2}{|l|}{ Tracked } & \multicolumn{3}{l|}{ Wheeled } & \multicolumn{2}{l|}{ Tracked } \\
\cline { 2 - 9 } & $\begin{array}{l}\text { Two } \\
\text { Lane }\end{array}$ & $\begin{array}{l}\text { One } \\
\text { Lane }\end{array}$ & $\begin{array}{l}\text { Two } \\
\text { Lane }\end{array}$ & $\begin{array}{l}\text { One } \\
\text { Lane }\end{array}$ & $\begin{array}{l}\text { Two } \\
\text { Lane }\end{array}$ & $\begin{array}{l}\text { One } \\
\text { Lane }\end{array}$ & $\begin{array}{l}\text { Two } \\
\text { Lane }\end{array}$ & $\begin{array}{l}\text { One } \\
\text { Lane }\end{array}$ \\
\hline MLC & 38 & 50 & 42 & 53 & 100 & 129 & 101 & 130 \\
\hline
\end{tabular}

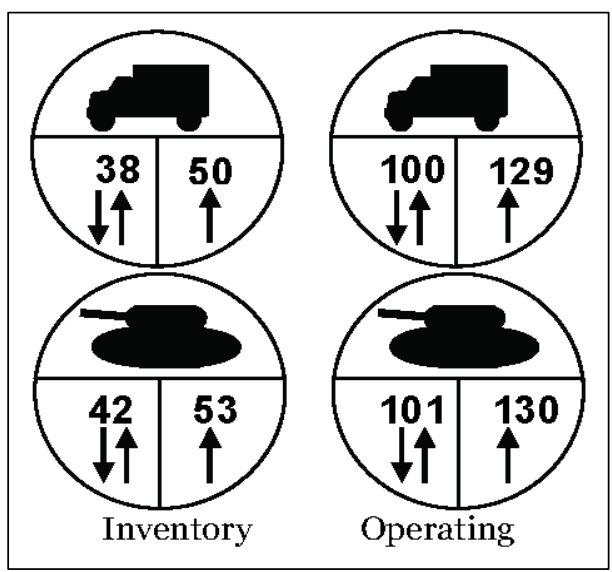

Figure 23. Bridge posting sign based on the ASR method. 


\section{References}

American Association of State Highway and Transportation Officials. 1994. AASHTO manual for condition evaluation of bridges. Washington, DC: American Association of State Highway and Transportation Officials, Inc.

American Association of State Highway and Transportation Officials. 2002. AASHTO standard specifications for highway bridges. 17th ed. Washington, DC: American Association of State Highway and Transportation Officials, Inc.

American Concrete Institute. 1992. Prediction of creep, shrinkage, and temperature effects in concrete structures. Committee Report 209. Detroit: American Concrete Institute.

Baes, L., and A. Lipski 1954. La poutre Preflex, Fascicule 2: Notes de calcul, Notes descriptive. Desoer, Liège, 1954, (in French).

Giacomo, S., and C. Mannini. 2006. Preflex beams: A method of calculation of creep and shrinkage effects. J ournal of Bridge Engineering ASCE 11 (2006): 48-58.

Headquarters, Department of the Army. 2001. U.S. Army military nonstandard fixed bridging. Field Manual 3-34.343. Washington, DC: Headquarters, Department of the Army.

SAMPYO Preflex Co., Ltd. 1985. Manual for elastic design of the preflex beam: SAMPYO Preflex Co., Ltd.

Staquet, S., G. Rigot, H. Detandt, and B. Espion. 2004. Innovative composite precast precambered U-shaped concrete deck for Belgium's high speed railway trains. Precast/ Prestressed Concrete Institute J ournal, 49.6 (November-December): 94-113.

Tadros, M., and N. Al-Omaishi. 2003. Pre-stress losses in pre-tensioned high-strength concrete bridge girders. National Cooperative Highway Research Program Report 496. Lincoln, NE: University of Nebraska. 


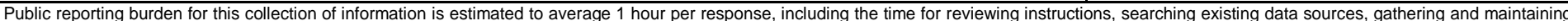

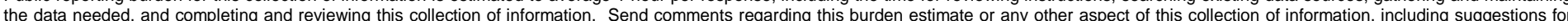

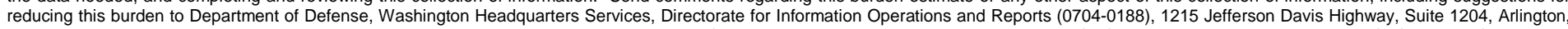

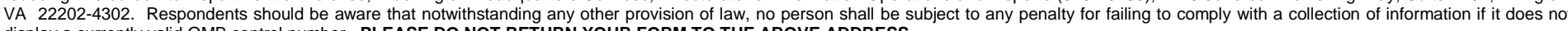
display a currently valid OMB control number. PLEASE DO NOT RETURN YOUR FORM TO THE ABOVE ADDRESS.
1. REPORT DATE (DD-MM-YYYY)
September 2011

\section{TITLE AND SUBTITLE}

Analysis and Load Rating of Pre-flex Composite Beams

3. DATES COVERED (From - To)

5a. CONTRACT NUMBER

5b. GRANT NUMBER

5c. PROGRAM ELEMENT NUMBER

\section{AUTHOR(S)}

Genock Portela, Ulises Barajas, and J osé A. Albarran-Garcia

5d. PROJECT NUMBER

5e. TASK NUMBER

5f. WORK UNIT NUMBER

8. PERFORMING ORGANIZATION REPORT NUMBER

ERDC/GSL TR-11-33

U.S. Army Engineer Research and Development Center

Geotechnical and Structures Laboratory

3909 Halls Ferry Road

Vicksburg, MS 39180-6199

\section{SPONSORING I MONITORING AGENCY NAME(S) AND ADDRESS(ES)}

Headquarters, Installation Management Command (ICOM)

San Antonio, TX 78201
10. SPONSOR/MONITOR'S ACRONYM(S)

11. SPONSOR/MONITOR'S REPORT NUMBER(S)

\section{DISTRIBUTION / AVAILABILITY STATEMENT}

Approved for public release; distribution is unlimited.

\section{SUPPLEMENTARY NOTES}

\section{ABSTRACT}

This report describes a methodology for analysis and load rating of pre-flex beams subjected to vehicular and military loads. The methodology is based on service limits for different loading stages. The analysis is divided into an initial stage of pre-flexion of the noncomposite beam, followed by the release and subsequent states of loading of a composite beam. Creep and shrinkage effects are considered in the analysis adopting Giacomo and Maninni (2006) and ACI 209 (1992) methods. An example bridge was used to describe a step-by-step process of analysis.

\begin{tabular}{|c|c|c|c|c|c|}
\hline \multicolumn{2}{|l|}{ 15. SUBJECT TERMS } & \multicolumn{2}{|l|}{ Load rating } & \multicolumn{2}{|c|}{ Military load classification } \\
\hline \multicolumn{2}{|l|}{ Pre-flex beam bridge } & \multicolumn{2}{|c|}{ Creep and shrinkage } & \multicolumn{2}{|c|}{ Composite } \\
\hline \multicolumn{2}{|c|}{ Pre-flex beam analysis } & \multicolumn{4}{|c|}{ High strength concrete } \\
\hline \multicolumn{3}{|c|}{ 16. SECURITY CLASSIFICATION OF: } & $\begin{array}{l}\text { 17. LIMITATION } \\
\text { OF ABSTRACT }\end{array}$ & $\begin{array}{l}\text { 18. NUMBER } \\
\text { OF PAGES }\end{array}$ & $\begin{array}{l}\text { 19a. NAME OF RESPONSIBLE } \\
\text { PERSON }\end{array}$ \\
\hline $\begin{array}{l}\text { a. REPORT } \\
\text { UNCLASSIFIED }\end{array}$ & $\begin{array}{l}\text { b. ABSTRACT } \\
\text { UNCLASSIFIED }\end{array}$ & $\begin{array}{l}\text { c. THIS PAGE } \\
\text { UNCLASSIFIED }\end{array}$ & & 89 & $\begin{array}{l}\text { 19b. TELEPHONE NUMBER (include } \\
\text { area code) }\end{array}$ \\
\hline
\end{tabular}

